\author{
Monograph \\ urn:1sid:zoobank.org:pub:EFD82C30-DBD4-40D0-8FE5-FAE10B7E560D
}

\title{
Revision of the genus Callipia Guenée, 1858 (Lepidoptera, Geometridae), with the description of 15 new taxa
}

\author{
Gunnar BREHM \\ Institut für Spezielle Zoologie und Evolutionsbiologie mit Phyletischem Museum, \\ Vor dem Neutor 1, 07743 Jena, Germany. \\ E-mail: gunnar.brehm@uni-jena.de
}

urn:Isid:zoobank.org:author:536E3B08-313E-4799-85D3-909216173100

\begin{abstract}
The vividly coloured Neotropical genus Callipia Guenée (1858) (Lepidoptera Linnaeus, 1758, Geometridae (Leach, 1815), Larentiinae (Leach, 1815), Stamnodini Forbes, 1948) is revised and separated into four species groups, according to a provisional phylogeny based on Cytochrome Oxidase I (COI) gene data and morphology. Fourteen new species are described using COI data and morphology: a) in the balteata group: C. fiedleri sp. nov., C. jakobi sp. nov., C. lamasi sp. nov.; b) in the vicinaria group: C. hausmanni sp. nov., C. walterfriedlii sp. nov.; c) in the parrhasiata group: C. augustae sp. nov., C. jonai sp. nov., C. karsholti sp. nov., C. levequei sp. nov., C. milleri sp. nov., C. sihvoneni sp. nov., C. wojtusiaki sp. nov. and d) in the constantinaria group: $C$. hiltae sp. nov., C. rougeriei sp. nov. One new subspecies is described: $C$. wojtusiaki septentrionalis subsp. nov. Two species are revived from synonymy: C. intermedia Dognin, 1914 stat. rev. and C. occulta Warren, 1904 stat. rev. The taxon hamaria Sperry, 1951 is transferred from being a junior synonym of $C$. constantinaria Oberthür, 1881 to being a junior synonym of $C$. occulta stat. rev. The taxon admirabilis Warren, 1904 is confirmed as being a junior synonym of C. paradisea Thierry-Mieg, 1904. The taxon languescens Warren, 1904 is confirmed as being a junior synonym of C. rosetta, Thierry-Mieg, 1904 and the taxon confluens Warren, 1905 is confirmed as being a junior synonym of $C$. balteata Warren, 1905. The status of the remaining species is not changed: C. aurata Warren, 1904, C. brenemanae Sperry, 1951, C. parrhasiata Guenée, 1858, C. flagrans Warren, 1904, C. fulvida Warren, 1907 and C. vicinaria Dognin. All here recognised 26 species are illustrated and the available molecular genetic information of 25 species, including Barcode Index Numbers (BINs) for most of the taxa is provided. The almost threefold increase from 10 to 26 valid species shows that species richness of tropical moths is strongly underestimated even in relatively conspicuous taxa. Callipia occurs from medium to high elevations in wet parts of the tropical and subtropical Andes from Colombia to northern Argentina. The early stages and host plants are still unknown.
\end{abstract}

Keywords. Callipia, taxonomy, Andes, insect, Neotropics.

Brehm G. 2018. Revision of the genus Callipia Guenée, 1858 (Lepidoptera, Geometridae), with the description of 15 new taxa. European Journal of Taxonomy 404: 1-54. https://doi.org/10.5852/ejt.2018.404

\section{Introduction}

Guenée (1858) described Callipia parrhasiata Guenée, 1858 in a new monotypic genus and illustrated this remarkable, vividly pink coloured species. The type was eventually deposited in the Natural History 
Museum (London). The locality is (according to its label) given as "Bengale" - obviously an error, since all confirmed records of species of Callipia are from the wet tropical Andes. In this revision, all specimens assigned to $C$. parrhasiata have been collected in a very limited geographic range in the eastern Andes of Ecuador. Only 23 years later the second species of the genus - C. constantinaria (Oberthür, 1881) - was described (Oberthür 1881). Twelve further taxa were described between 1904 and 1914 by Thierry-Mieg (1904), Warren $(1904,1905,1907)$ and Dognin $(1913,1914)$, and two by Sperry $(1951)$, reflecting a typical temporal pattern and peak of taxonomic activity around 1900 also found in many other Neotropical geometrid taxa (Gaston et al. 1995; Brehm et al. 2011; Brehm 2015). In their catalogue of geometrid moths, Parsons et al. (1999) treated 15 of these 16 taxa; only the taxon C. confluens Warren, 1907 is not listed in the catalogue, it was originally described as a form of Callipia balteata Warren, 1905. Parsons et al. (1999) recognised ten valid taxa and five junior synonyms.

Whenever possible, this paper aims to integrate results from external morphology, genitalia morphology and molecular genetics, i.e., from "DNA barcoding" of the Cytochrome Oxidase I (COI) gene. COI barcoding allowed a reliable match between males and females in several cases and eased the sorting of difficult species complexes considerably. In the large majority of cases, molecular and morphological results were congruent, but in some cases, DNA barcoding produced splits in taxa that were morphologically otherwise not distinguishable. I generally followed DNA barcoding results and applied a $2 \%$ threshold for the separation of species with the exception of the C. milleri - wojtusiaki complex. Barcode Index Numbers (BINs) were assigned to each species when available, a system that has been established by the Barcode of Life Data Systems (www.boldsystems.org) (Ratnasingham \& Hebert 2013). Twenty-one different BINs are assigned to species of Callipia in this paper, thus covering $75 \%$ of the valid species. In one species complex, I assigned two different BINs not to different species, but to geographically separated subspecies. The BIN system allows a quick and reliable assignment of DNA-barcoded specimens. This is particularly valuable in cryptic and difficult species complexes in poorly known faunas (Brehm et al. 2016). Assignment of DNA barcodes to described species was performed by careful comparison of type material with freshly collected material (Brehm 2015; Brehm et al. 2016), and all relevant types and vouchers are illustrated in this paper. DNA-barcoded material also includes six old specimens collected between 30 and 100 years ago in a couple of cases where no fresh material was available (Strutzenberger et al. 2012).

Most historical descriptions of Callipia consist of a few text lines only that describe external characters and the colour patterns of the moths. Today, the study of external and internal morphological characters in combination with genetic characters and colour illustrations provides far better opportunities for taxonomy than ever. However, the wealth of options to describe a new taxon also means a burden for taxonomic work, because the description of species could include the study and illustration of dozens, if not hundreds of characters. If these are met at high standards, descriptions will not only fare better than in the past, but unfortunately, also consume much more time. Given the severe and rapid loss of biodiversity and the need of sound taxonomic information, especially in tropical regions, I here choose a treatment that focuses on diagnostic characters, high resolution illustrations with standardized scale bars and standard gene sequences. On the other hand, I have decided to waive extensive and detailed descriptions of characters that are diagnostically not valuable and/or plesiomorphic (Forum Herbulot 2014; Brehm 2015).

Callipia is assigned to the geometrid subfamily Larentiinae (Parsons et al. 1999). Viidalepp (2011) confirmed this position and further assigned Callipia to the tribe Stamnodini Forbes, 1948. Besides a butterfly-like vertically folded resting position of the wings (also found in, e.g., Hagnagora Druce, 1885 and Heterusia Hübner, 1831, see Brehm 2015), the Stamnodini are characterised by certain structures of the male genitalia (Viidalepp 2011). The author states that the juxta is shield-shaped and has a specific ornamentation, and the valvae have a strong costal hair lock (Viidalepp 2011). The placement in the 
Larentiinae was also confirmed by recent molecular phylogenetic analyses (Sihvonen et al. 2011; Ounap et al. 2016). The tribe Stamnodini (as represented by Callipia) is sister to the tribe Erateini Guenée, 1858 (as Erateinidae) (as represented by 'Trocherateina' cachara) (Sihvonen et al. 2011; Viidalepp 2011). However, due to incomplete taxon sampling, phylogenetic relationships of Callipia and other Stamnodini within the Larentiinae Duponchel, 1845 require further examination.

\section{Material and methods}

Moths were pinned and dissected following established techniques (e.g., Lafontaine 2004; Hünefeld et al. 2013). Genitalia slides were embedded in Euparal, stained with Chlorazol Black and digitised at least 10 weeks after production using an Olympus dotSlide system with $10 \times$ magnification. Adult moths were photographed on a neutral grey background in raw format using a $60 \mathrm{~mm}$ Nikkor macro lens mounted on a Nikon D700 camera. Photos were adjusted and colour plates were mounted using Photoshop and InDesign software (Adobe Systems, San José, USA).

Sequencing of the barcode fragment of the COI gene was carried out at the Canadian Center for DNA barcoding in Guelph, Ontario. Barcode sequences were compared by nearest neighbour analyses (Kimura 2 parameter), as implemented on the Barcode of Life Data Systems website (Ratnasingham \& Hebert 2007). The resulting tree represents preliminary hypotheses of taxa groupings and can form the basis of future phylogenetic work (Brehm 2015) (Fig. 1). For eight old specimens, a six fragments approach was performed that was originally developed for Sphingidae (Lees et al. 2011; Rougerie et al. 2012), but also successfully applied to Geometridae (Strutzenberger et al. 2012). Distribution maps display only such specimens with original coordinate data on their labels, or specimens labelled with localities that could be found with reasonable certainty, e.g., using Google Earth software. Localities were checked using Lamas (1976), and in correspondence with Gerardo Lamas (personal communication, Peru) and Sebastian Herzog (personal communication, Bolivia). In order to keep an overview and to allow easy tracking of specimens for later analyses, every specimen that was investigated and did not already possess a unique museum identification number was labelled with an individual number, ranging from "Callipia-gb 0001" to "Callipia-gb 0432" (abbreviated as C-0001 to C-0432). Individual numbers were not provided for some of the existing type specimens. Genitalia slides were produced for ca 130 specimens. They are labelled for example "Genitalia slide Gunnar Brehm 399" (abbreviated GS-399). Sampling locations are generally ordered from north to south.

\section{Museum acronyms}

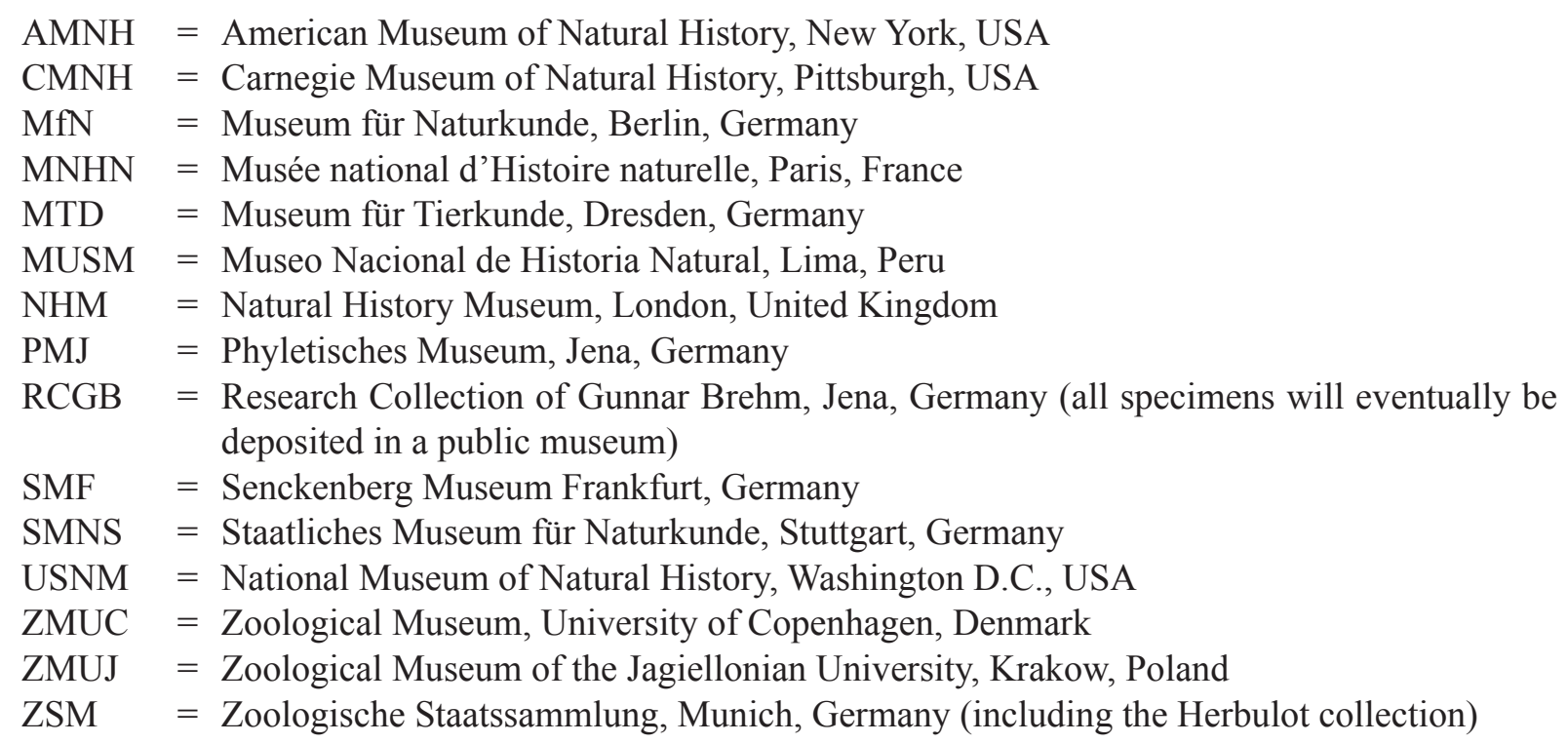




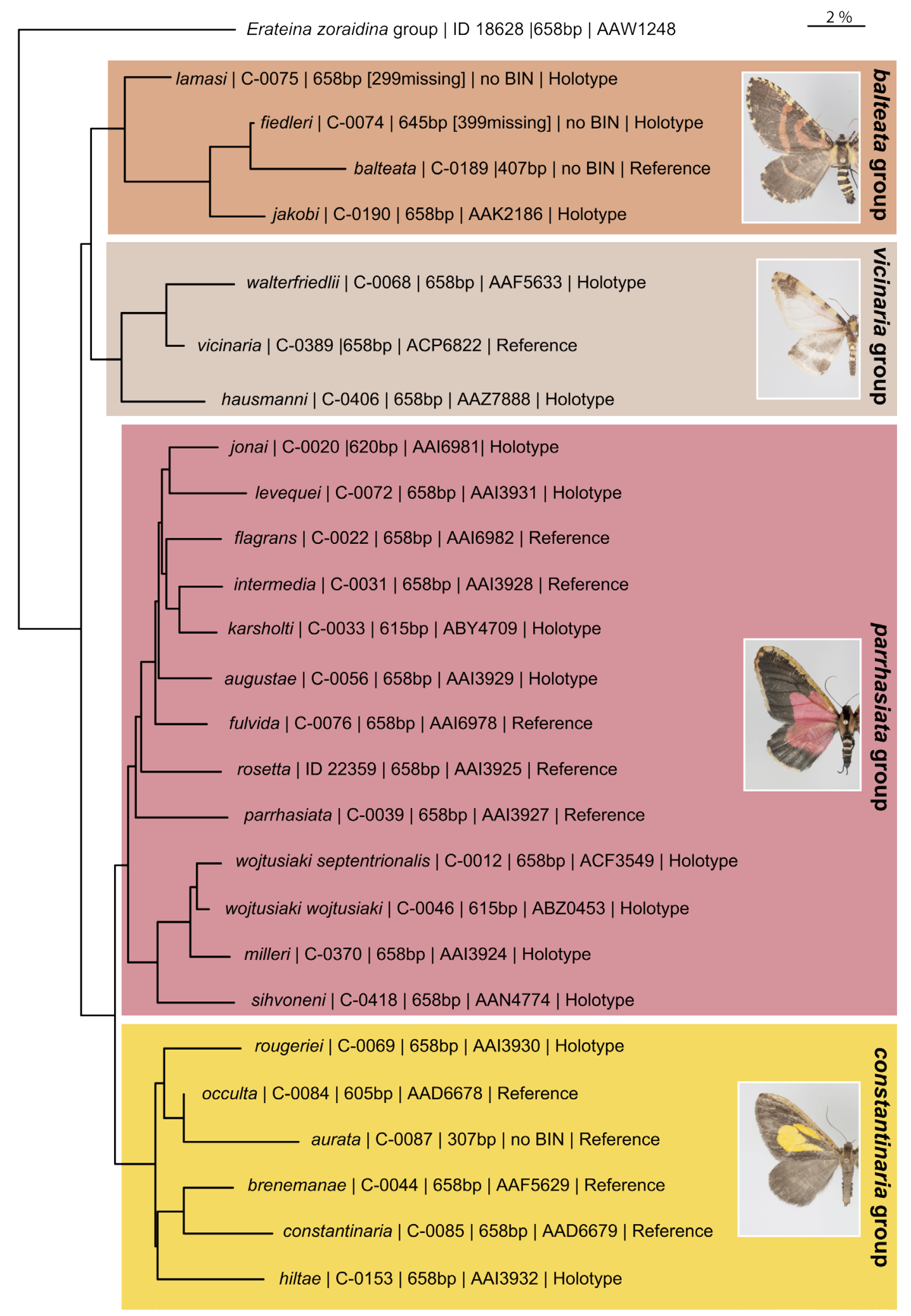

Fig. 1. Summary tree of the available molecular genetic data based on genetic COI barcodes using the Kimura 2 parameter implemented in BOLD systems. All valid species with the exception of Callipia paradisea Thierry-Mieg, 1904 are represented by the barcode data, either by type specimens or as reference specimens. The species name is followed by the individual identification number and the Barcode Index Number (BIN). A full tree is available in the supplementary material (Supplementary File 1). 
Localities are mostly quoted according to the original label, with my emendations between square brackets.

\section{Results}

In this paper, two taxa are revived from synonomy. With the addition of 15 new taxa, Callipia now comprises 26 valid species, one subspecies and 4 junior synonyms.

\section{General short description}

With its large size, typically shaped forewings and colourful wing patterns, Callipia forms a distinct group within the Neotropical Larentiinae that made assignment of newly described species to this genus easy. In contrast to most other Neotropical larentiin genera, all described species were originally assigned to the genus they are still assigned to. During visits to various museums holding Neotropical material, I have not come across species that need to be transferred to Callipia, either.

Compared to most other larentiines, Callipia are very large moths, with wing lengths ranging from ca $24 \mathrm{~mm}$ up to ca $32 \mathrm{~mm}$. As a comparison, the three most species rich Neotropical genera Eupithecia Curtis, 1825, Eois Hübner, 1818 and Psaliodes Guenée, 1858 only reach wing lengths up to ca 13 to $14 \mathrm{~mm}$.

\section{Wings}

Callipia are exceptionally colourful geometrids, most species possess wing patterns with large rosypink, yellow or red blotches on the wings. The function of these conspicuous colours is unknown, because the moths always rest with vertically folded wings, and their colourful patterns remain largely unseen, see Figs 135 and 137. They have this in common with related genera such as Heterusia Hübner, 1831, Erateina Doubleday, 1848 and Hagnagora Druce, 1885 (Brehm 2015). Many butterflies and other insects with striking colours during flight are well camouflaged when they rest. It is possible that that the conspicuous patterns are shown when the moths are disturbed, but this has not been observed so far. In other colourful Neotropical geometrid genera such as Heterusia and Erateina diurnal activity or activity at day and night was recorded (Brehm \& Sullivan 2005). However, diurnal behaviour has so far to my knowledge not been documented in Callipia, but it is possible that the moths show their colours when disturbed, fly away and hide again well camouflaged.

Callipia can also be distinguished from other geometrids by their typically shaped forewings which are "higher than broad", i.e., the outer margin of the fore wing stretches longer than veins $1 \mathrm{~A}+2 \mathrm{~A}$. While the fore wing pattern can vary considerably between species, the underside of the hindwings is rather uniform among most species of Callipia: with a dark brown background colour, they are ochreously striated in such a way that it resembles an irregular orb spider web. Similar striae also occur in the apical region of the underside of the fore wing - the only exception being C. rougeriei sp. nov. in which striae are completely reduced. Most species possess a cream white postmedial line on the underside of the hindwing, but it is largely reduced in the constantinaria group and widened to a large white blotch in C. paradisea Thierry-Mieg, 1904.

\section{Colour}

The ground colour in all species is dark to medium brown.

\section{Head (illustrated by Viidalepp 2011), thorax and abdomen}

Appear not to possess particular characters that can be interpreted as an apomorphy of the genus. Head: proboscis, compound eyes and labial palpi are well developed, and the antennae are filiform in both sexes. Thorax: the tegulae are often light ochreous, contrasting with the dark brown scutum, the legs are usually 
brown. The tibia spur formula is $0-2-4$ as found in most other Geometridae (Scoble 1992). Abdomen: tympanal organs are well developed. The colour of the abdomen in most species consists dorsally (and in some species also laterally) of alternate ochreous and brown rings in each segment, most prominently in the balteata group, but absent in several species, particularly in the constantinaria group.

\section{Male genitalia}

The valvae are broad and rounded, hemitranstilla (sensu Viidalepp 2011) are present, the juxta is shield shaped (Viidalepp 2011) and many species possess a spine-like process on the ventral margin of the valvae. The uncus is slender with a sharp or round apex, the sacculus is round. The aedeagus is enclosed in a sclerotized tube - the manica sensu Viidalepp (2011). The shape of the manica varies considerably between species.

\section{Female genitalia}

A signum is not visible on the corpus bursae, the lamella antevaginalis is small, sclerotised, often lunular; the ductus bursae is short, narrow and sclerotised; the ductus bursae is without sclerotisations, its shape varying from narrow and elongated to more roundish.

\section{Preimaginal stages and host plants}

Preimaginal stages and host plants are unknown.

\section{Phylogenetic information summary}

Figure 1 shows a summary tree with each DNA-barcoded species represented by one specimen per species. It visualizes similarities and differences in the COI gene between the different taxa and it was instrumental in differentiating four clades identified within Callipia. One species, paradisea, could not be reliably assigned to one of these clades. The four clades are subsequently treated as balteata group, vicinaria group, constantinaria group and parrhasiata group, named after the oldest available name in each of the clades. Table 1 provides an overview of all taxa, including available molecular genetic information and currently known distribution. Detailed information on all examined species can be found in Supplementary File 2. Further details for 150 specimens, including voucher images and molecular data, are publicly available in BOLD and can be accessed under https://doi.org/10.5883/DS-CALL2017

\section{Distribution, habitats and behaviour}

Specimens of Callipia were collected in Ecuador using blacklight and blacklight-blue tubes (Brehm \& Axmacher 2005), and in Peru with a newly developed UV LED lamp (Brehm 2017). All specimens illustrated in Figs 131-139 were collected in this way and photographed either on the surface of the 'light tower', or in the vegetation next to the light source. Specimens of Callipia were often shy and escaped when they were disturbed. Figures 131 and 133, therefore, show benumbed specimens. Other investigated adult specimens have usually been collected with lamps as well, but in most cases this is not explicitly documented on the labels.

Figure 2 shows the distribution data of those specimens of Callipia with reliable locality information. In addition, a kml file (Supplementary File 3) allows to explore the distribution data in detail using Google Earth software. So far, examined specimens of Callipia have been collected in the Andes from Colombia (Boyacá, $5^{\circ} \mathrm{N}$ ) to northern Argentina (Tucumán, 26 ${ }^{\circ} \mathrm{S}$ ). In Colombia and Ecuador, Callipia have been observed in both (wet) Cordilleras. However, further south, they are restricted to a narrow band along the Amazonian slopes of the Eastern Andes with wet montane forests, cloud forests and high elevation paramo and puna vegetation. Some of the habitats are illustrated in Figs 132, 136 and 138. Callipia appear to be restricted to humid areas, because none have been recorded in dry south western Ecuador, western Peru and Bolivia, or in Chile. Specimens of Callipia obtained from many museum 


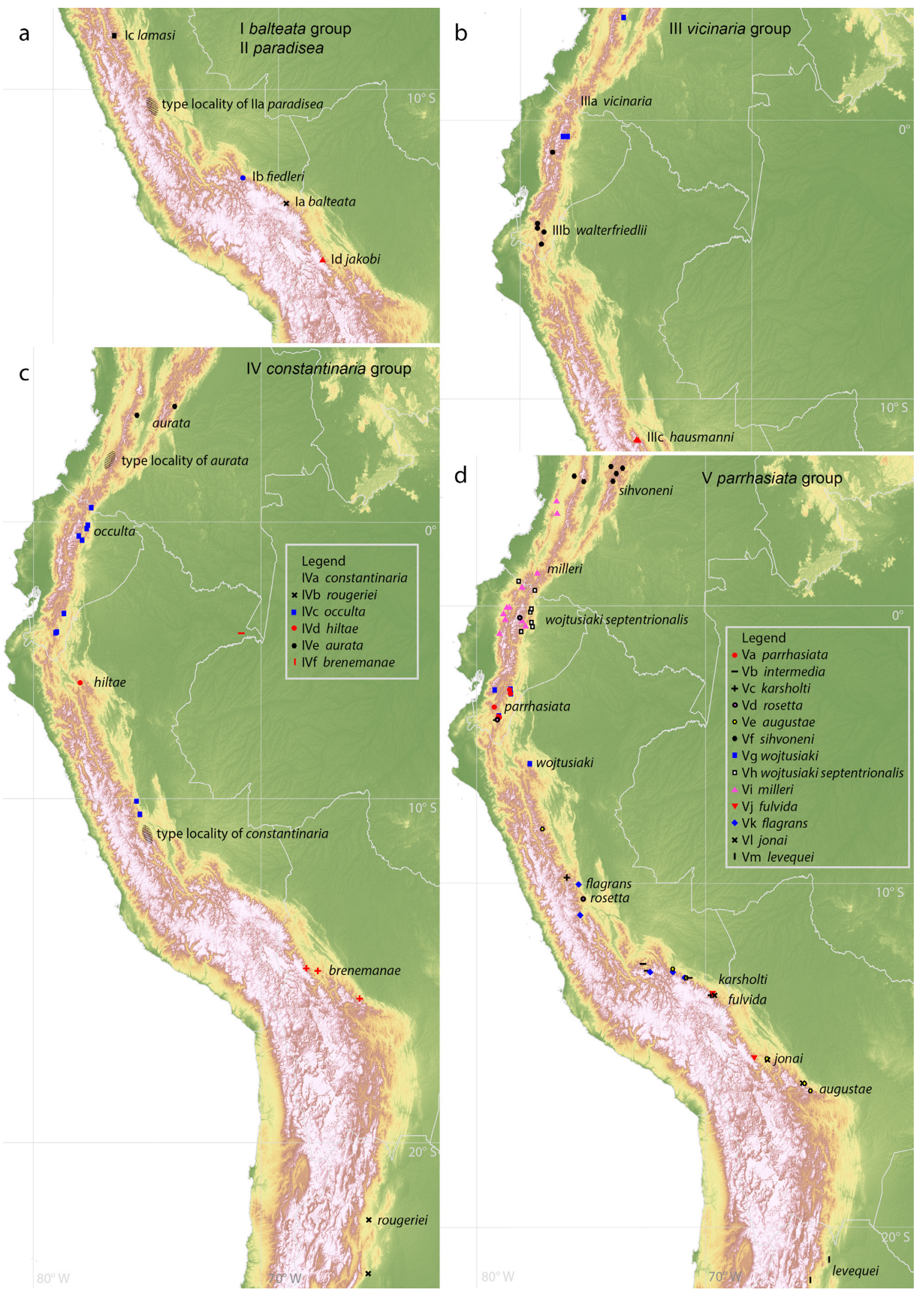

Fig. 2. Distribution maps. A. The balteata group and Callipia paradisea Thierry-Mieg, 1904. B. The vicinaria group. C. The constantinaria group. D. The parrhasiata group. More details can be retrieved from a Google Earth kml file (Supplementary File 3). 


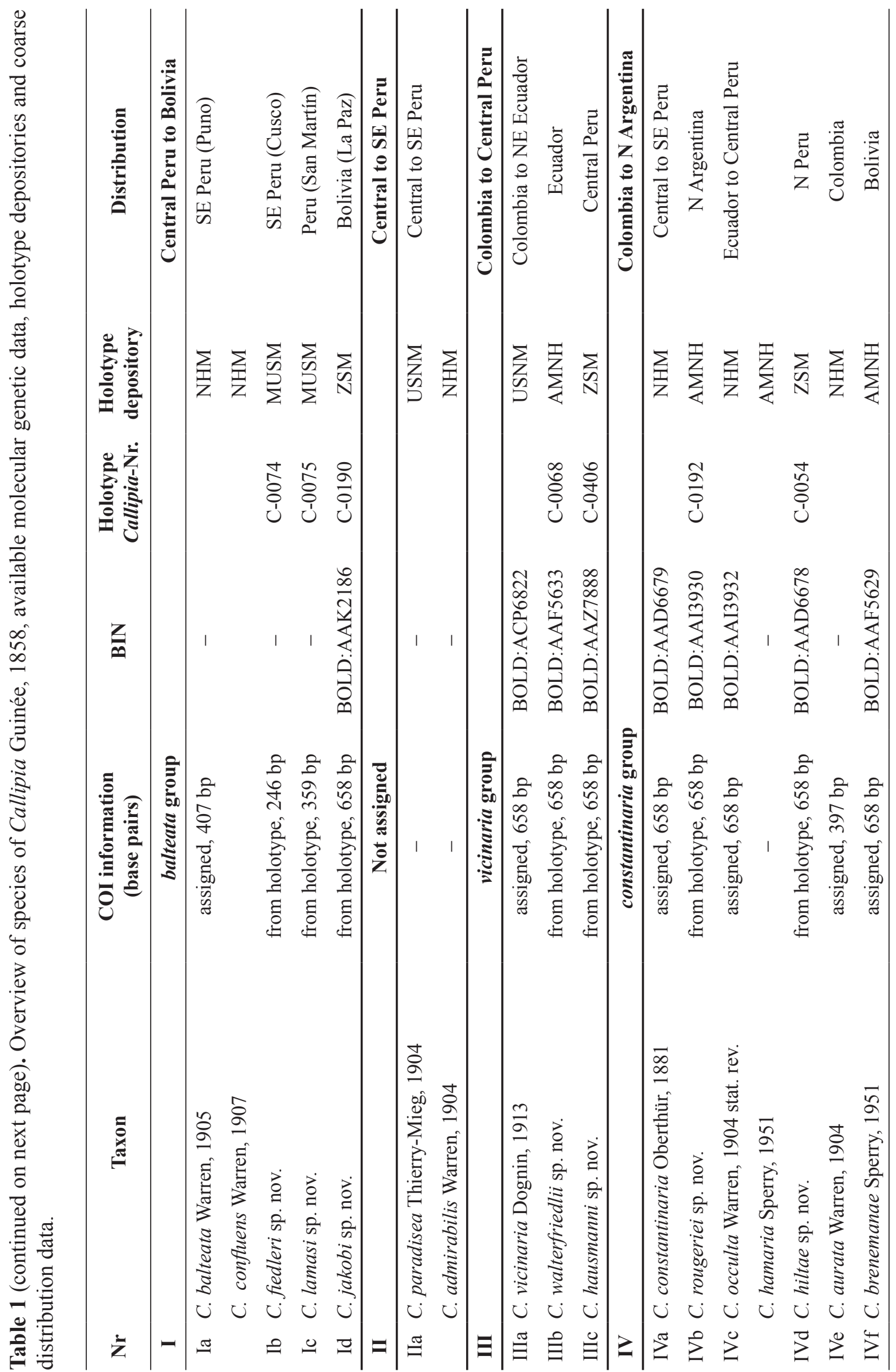




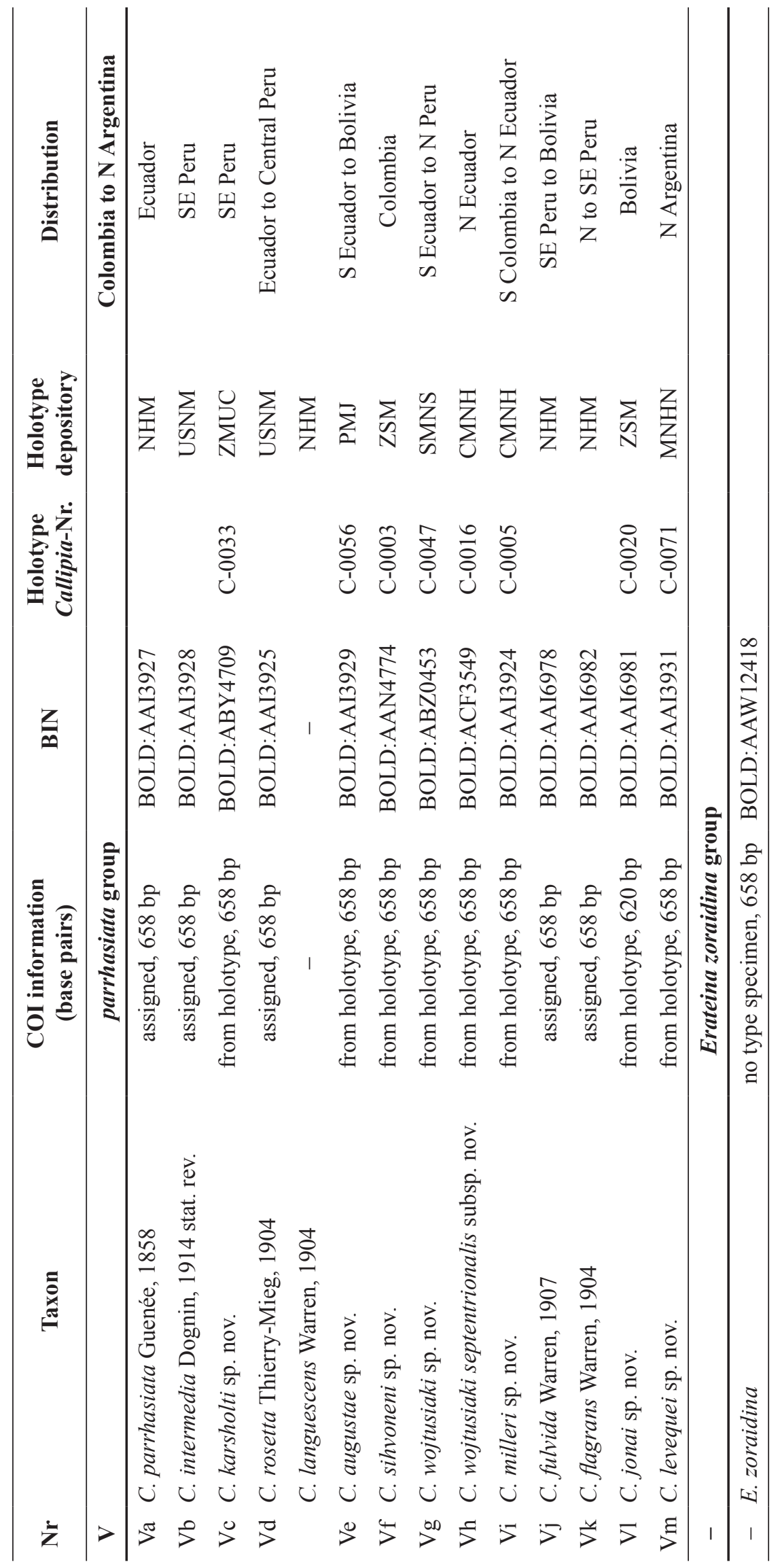


collections have not been sampled in northern Colombia and in Venezuela either, but this might reflect a sampling artifact. Many regions are still undersampled, such as large ranges of the Andes in northern and central Peru and in southern Bolivia. More sampling will certainly improve the knowledge of the distribution of Callipia and will inevitably reveal further undiscovered taxa. Callipia appears to be restricted to the Andes and is absent from Central America. It is a truly Andean taxon, similarly as, e.g., the Acrotomodes clota group (Ennominae Duponchel, 1845) (Brehm 2005). The most widely distributed clade is the parrhasiata group that ranges from Colombia to northern Argentina, with the highest species richness found in Peru. Similarly, widely distributed is the constantinaria group, but it has a smaller species richness. The other groups are geographically more restricted (Fig. 2).

Although there are records of Callipia from lowland tropical forests (e.g., $200 \mathrm{~m}$ in Madre de Dios, Peru and $450 \mathrm{~m}$ in Tena, Napo, Ecuador), these cases are exceptional and would need to be confirmed mislabelling appears very likely. Most tropical species of Callipia are not found below $1500 \mathrm{~m}$ a.s.l. Some, such as species belonging to the balteata group, have only been recorded at elevations around or higher than $3000 \mathrm{~m}$ a.s.1.

\section{The balteata group}

The four known members of the balteata group possess two distinctive broad, deep rosy bands on the forewing; a pattern that is not found in other species of Callipia. The male valvae are round-shaped and do not possess the spine-like processes on the ventral margin that are present in all other groups of Callipia. The uncus is pointed. The aedeagi are bulkier than in other Callipia, the vesica is long and has a small series of cornuti. The species are restricted to high elevations in the wet eastern Peruvian and Bolivian Andes (observed: 1982-3450 m). All are represented by a single or very few specimens in museum collections only. Surprisingly, the balteata group consists of relatively many species, with small, but clear morphological differences besides supporting molecular information. One species was collected in Huánuco Province, Central Peru (C. lamasi sp. nov.), ca $850 \mathrm{~km}$ separated from the collection site of $C$. fiedleri sp. nov. (Peru, Cusco Province), separated by ca $250 \mathrm{~km}$ from the collection site of C. balteata (Peru, Puno Province) and separated by another ca $250 \mathrm{~km}$ from the collection site of $C$. jakobi sp. nov. (western Bolivia). The balteata group represents an example of an Andean high elevation clade with a large degree of local endemism. The females are still unknown.

Class Hexapoda Blainville, 1816

Order Lepidoptera Linnaeus, 1758

Superfamily Geometroidea Leach, 1815

Family Geometridae Leach, 1815

Subfamily Larentiinae Duponchel, 1845

Tribe Stamnodini Forbes, 1948

Genus Callipia Guenée, 1858

Callipia balteata Warren, 1905

Figs 3-5, 9-10

Callipia balteata confluens Warren, 1907: 243. (Fig. 5). Syn. nov.

No assigned BIN, but assigned 407 bp fragment.

\section{Diagnosis}

See the three other species of the group. COI-barcode: the observed distance to the genetically most similar species (C. fiedleri sp. nov.) is $3.3 \%$. 


\section{Type material}

Holotype (Figs 3, 9)

PERU: đ̃, south east Peru [Puno], Carabaya, Santo Domingo, 6500 ft [1982 m], Jan. 1902, dry season, [G.R.] Ockenden leg. (NHM).

\section{Other type material}

PERU: Ô, holotype of balteata confluens Warren, 1907 (Fig. 5), [Puno], Carabaya, Agualani, $9000 \mathrm{ft}$ [2743 m], Mar. 1905, wet season, [G.R.] Ockenden leg. (NHM) [Originally as form].

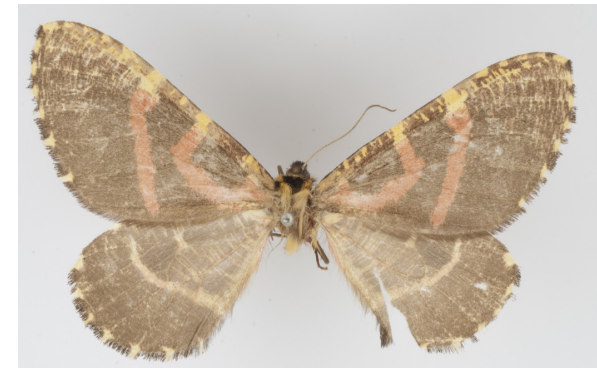

3a balteata $\sigma^{\nearrow}$, holotype

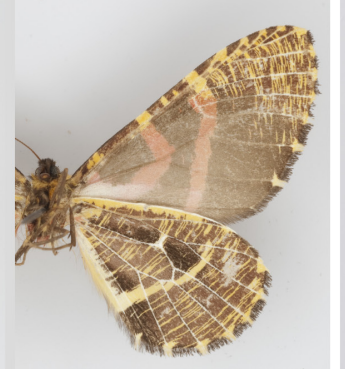

$3 b$

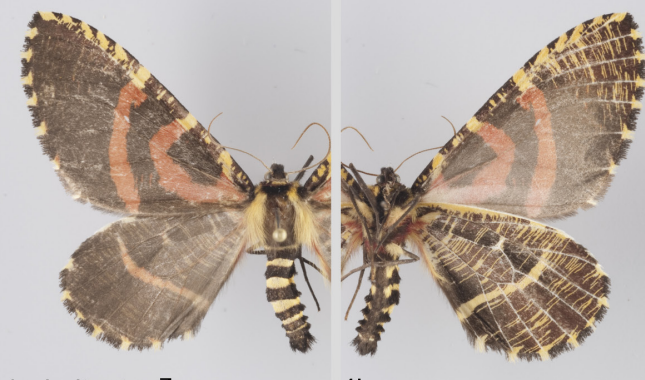

4 a balteata $\sigma^{\top}$

$4 \mathrm{~b}$

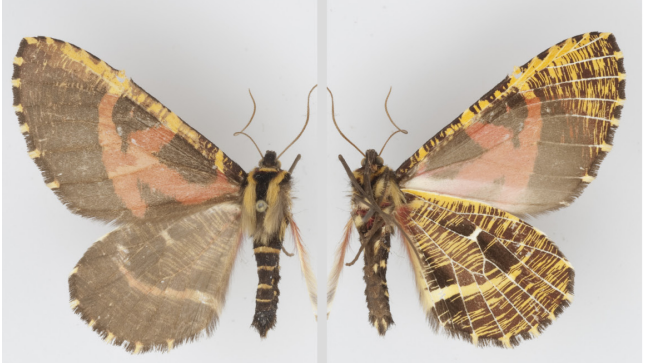

$5 a-b$ balteata $\sigma^{\top}$, holotype of confluens

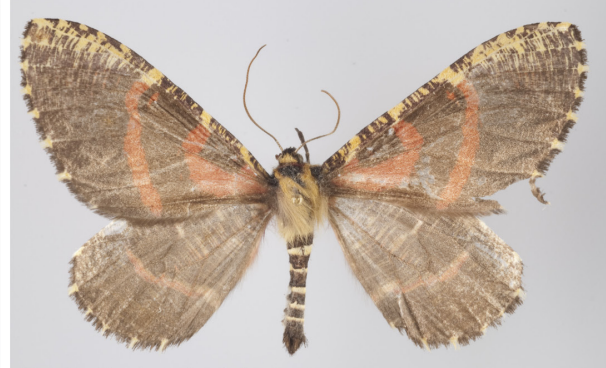

6a fiedleri $0^{7}$, holotype
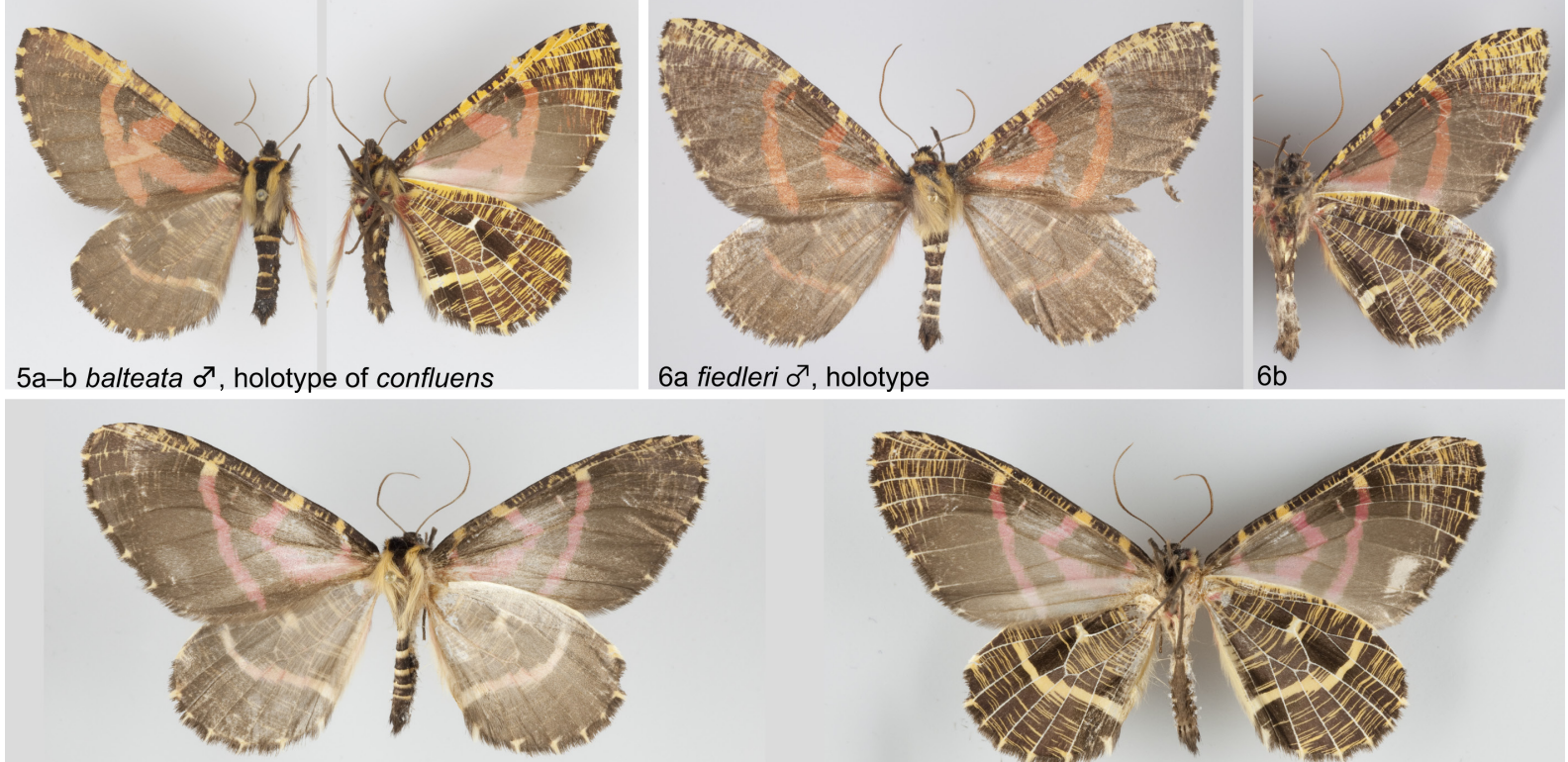

7a lamasi $\sigma^{\top}$, holotype

$7 \mathrm{~b}$
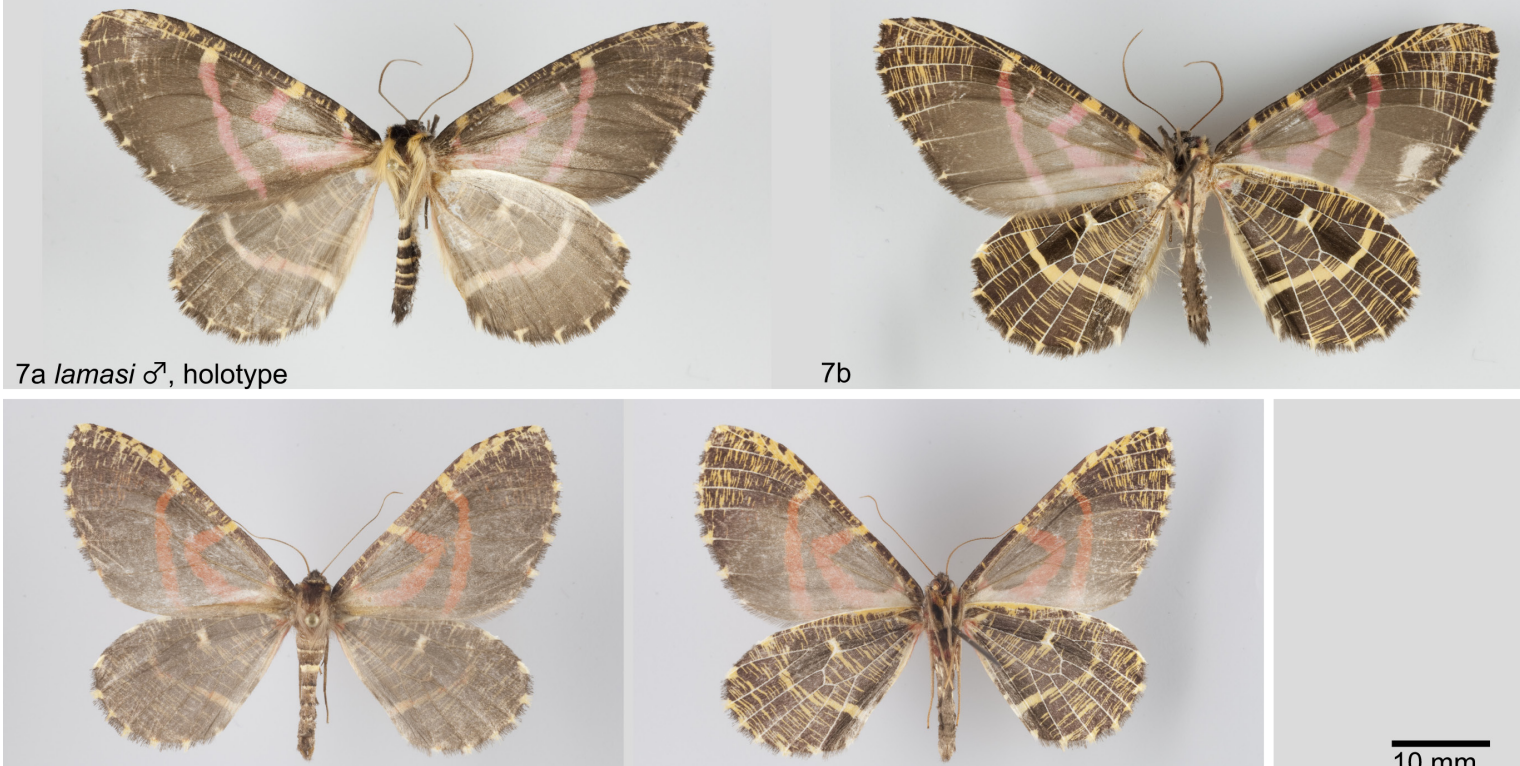

8a jakobi ơ , holotype

$8 b$

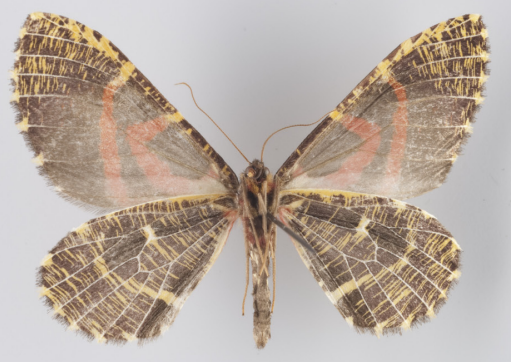

Figs 3-8. Eight adult moths $(\mathrm{a}=$ dorsal view; $\mathrm{b}=$ ventral view). 3. Callipia balteata Warren, 1905, $\widehat{\sigma}$, holotype (NHM). 4. C. balteata Warren, 1905, §̊ (C-0189, COI data). 5. C. balteata Warren, 1905 (holotype of C. confluens Warren, 1907) (NHM). 6. C. fiedleri sp. nov., đ̂, holotype (C-0074, COI data). 7. C. lamasi sp. nov., ڤ̂, holotype (C-0074, COI data). 8. C. jakobi sp. nov., ô, holotype (C-0190, COI data). 

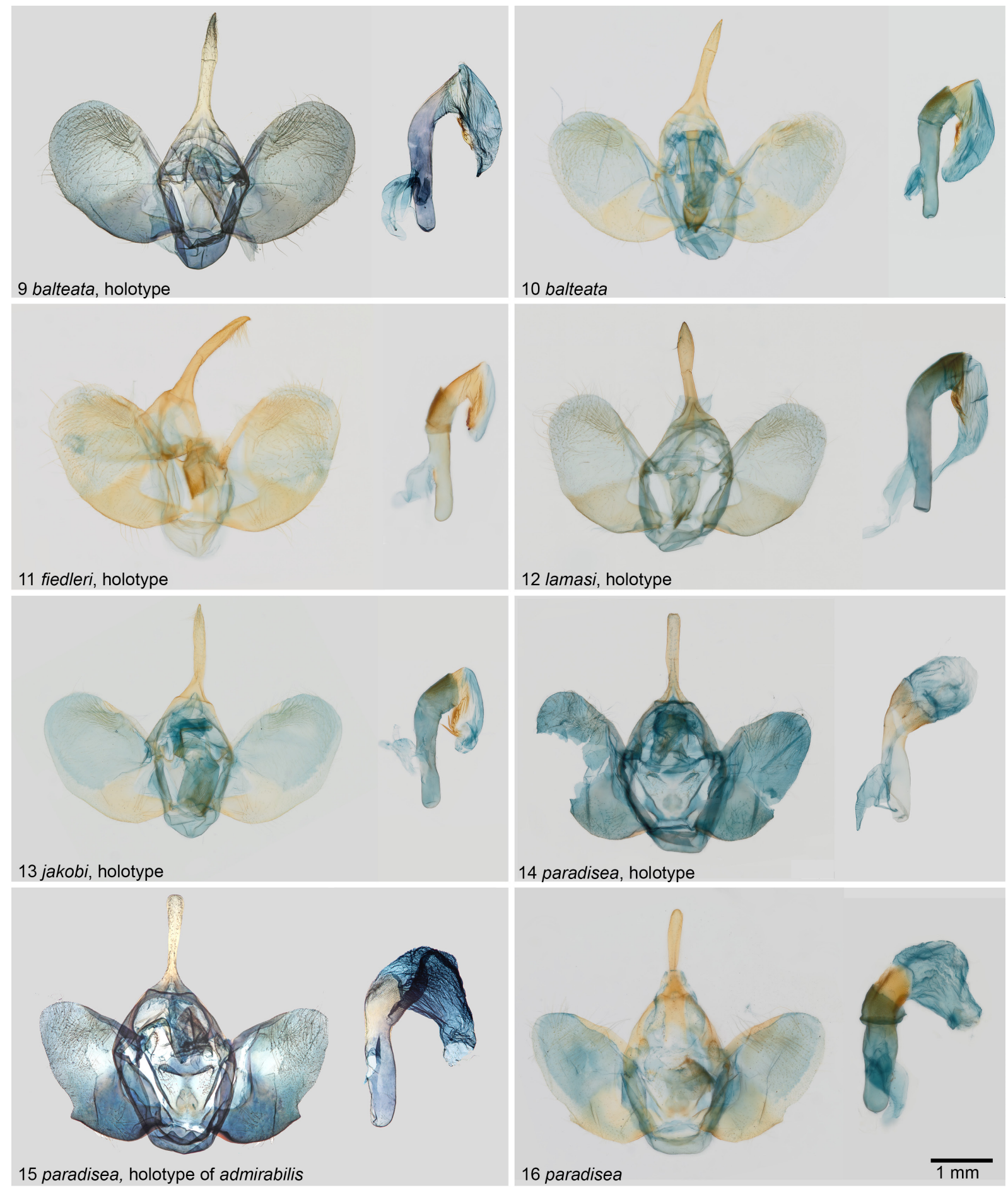

Figs 9-16. Male genitalia (left: valves, right: aedeagus). 9. Callipia balteata Warren, 1905, holotype. 10. C. balteata Warren, 1905 (C-0189, COI data). 11. C. fiedleri sp. nov., holotype (C-0074, COI data). 12. C. lamasi sp. nov., holotype (C-0075, COI data). 13. C. jakobi sp. nov., holotype (C-0190, COI data) 14. C. paradisea Thierry-Mieg, 1904, holotype (C-0194). 15. C. paradisea Thierry-Mieg, 1904 (holotype of C. admirabilis Warren, 1904) (NHM). 16. C. paradisea Thierry-Mieg, 1904. 


\section{Other material examined}

PERU: 1 ๙ , Puno, 5 km E of Limbani, 3000 m (ZMUC) (C-0189 with GS-417, COI sequence: 407 bp, Figs 4, 10); 1 đ̂, Carabaya, Agualani, 9000 ft [2743 m], Apr. 1905 (NHM) (C-0090).

\section{Description}

As illustrated. Female unknown.

\section{Distribution}

South eastern Andes of Peru, 2000-3000 m.

Callipia fiedleri sp. nov.

urn:Isid:zoobank.org:act:DBD4E060-1768-4EA1-970A-6A8651310369

Figs 6, 11

No assigned BIN but 246 bp fragments (399 bp gap).

\section{Diagnosis}

Similar to C. balteata, but the two bands on the forewing further apart, the cream white band on the hindwing underside is very narrow. Vesica of the aedeagus is shorter than in C. balteata. COI-barcode: the observed distance to the genetically most similar species (C. balteata) is $3.3 \%$.

\section{Etymology}

The species is named in honour of Konrad Fiedler, Vienna, Austria.

\section{Type material}

Holotype (Figs 6, 11)

PERU: ${ }^{\top}$, Cusco, Abra Acjanaco [13.201 S, $71.627^{\circ} \mathrm{W}$ ], 3200-3450 m, 7 Jul. 1991, M. Medina leg. (MUSM) (C-0074 with GS-396, COI sequence: 246 bp [399 bp gap]).

\section{Description}

As illustrated. Only a single male is known.

\section{Distribution}

Only known from a single high-elevation locality in the south eastern Andes of Peru, 3200-3450 m, ca $250 \mathrm{~km}$ north-west of the collection sites of $C$. balteata.

Callipia lamasi sp. nov. urn:lsid:zoobank.org:act:B6050BC5-F312-468D-87D0-1A90573BDB1E

Figs 7, 12

No assigned BIN, but holotype with COI 359 bp fragments [299 bp gap].

\section{Diagnosis}

The largest member of the balteata group, patterns strikingly contrasting, colour of the bands on the forewing upperside distinctly pink, and not red-brown as in the related species. The uncus is broader than in the other species. COI-barcode: the observed distance to the genetically most similar species (C. jakobi sp. nov.) is $6.0 \%$. 


\title{
Etymology
}

The species is named in honour of Gerardo Lamas (MUSM), Lima, Peru.

\section{Type material}

Holotype (Figs 7, 12)

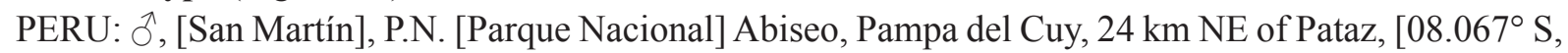
$77.236^{\circ}$ W], 3380 m, 10 Aug. 1987, M. Romo leg. (MUSM) (C-0075 with GS, COI sequence 359 bp fragments (299 bp gap)).

\section{Description}

As illustrated. Only a single male is known.

\section{Distribution}

Only known from a single locality in the Central Eastern Andes of Peru, 3400 m, ca 850 km north west of the collection site of $C$. fiedleri sp. nov.

\author{
Callipia jakobi sp. nov. \\ urn:1sid:zoobank.org:act:3D00FE40-D169-4ED1-9CD8-B6424EF12955 \\ Figs 8,13
}

BIN (holotype): BOLD:AAK2186.

\section{Diagnosis}

The smallest species of the balteata group, relatively pale and less contrasting patterns of the wings than in the other species. The cornuti of the vesica are much longer than in the other species of the balteata group. COI-barcode: the observed distance to the genetically most similar species (C. balteata) is $4.3 \%$.

\section{Etymology}

The species is named in honour of my son Jakob Brehm, Jena, Germany.

\section{Type material}

Holotype (Figs 8, 13)

BOLIVIA: ${ }^{\top}$, [La Paz Department], Route La Paz-Rio Songo [Rio Zongo, ca $16.104^{\circ} \mathrm{S}, 68.065^{\circ} \mathrm{W}$ ], 3300 m, 3 Mar. 1984, G. Lachaume and T. Porion leg. (ZSM) (C-0190 with GS-409, COI sequence 658 bp, BIN).

\section{Description}

As illustrated. Only a single male is known.

\section{Distribution}

Eastern Andes of W Bolivia, $3300 \mathrm{~m}$ a.s.1. Distance to the collection site of C. balteata is ca $250 \mathrm{~km}$.

\section{Without assignment to group}

Callipia paradisea is known from a few specimens only. Wing patterns and structure of male genitalia not easily fitting into any of the other groups, but vicinaria group is possibly most closely related. Since no molecular data are available either, $C$. paradisea is provisionally treated separately. 
Callipia paradisea Thierry-Mieg, 1904

Figs 14-19

Callipia admirabilis Warren, 1904: 538 (confirmed junior synonym of C. paradisea, see Parsons et al. 1999) (Figs 15, 19).

No assigned BIN.

\section{Diagnosis}

Callipia paradisea is unmistakeable due to its unique mixed colour pattern of white, dark brown and extended rosy elements. The taxon $C$. admirabilis does not show any significant differences from the type specimen of $C$. paradisea and, therefore, remains in synonymy with $C$. paradisea. The other four species of the vicinaria group are smaller than C. paradisea. Male genitalia: a spine-like process on the ventral margin of the valvae is present, but short and blunt. The aedeagus is broader than in most other species, the manica is slightly bent, and the vesica does not possess cornuti.

\section{Type material}

Holotype (Figs 14, 17)

PERU: $\widehat{\jmath}$, [Pasco], Huancabamba, 6000-10000 ft [1829-3048 m], 1903 (C-0194 with GS-291) (USNM).

\section{Other type material}

PERU: $\lambda$, holotype of C. admirabilis Warren, 1904 (confirmed junior synonym of C. paradisea) (Figs 15, 19), Peru, [Pasco], Huancabamba, Cerro de Pasco, [E.] Böttger leg. (NHM).

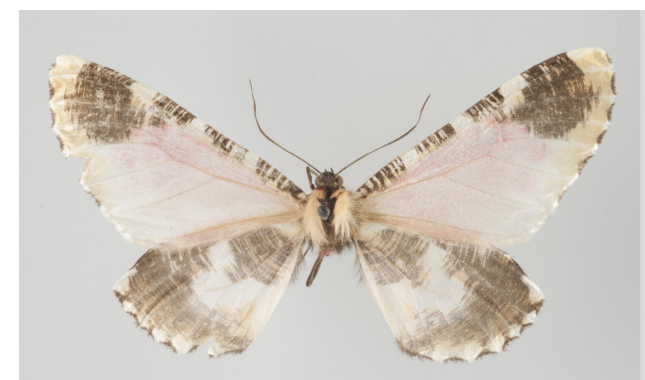

17a paradisea $\sigma^{\top}$, holotype

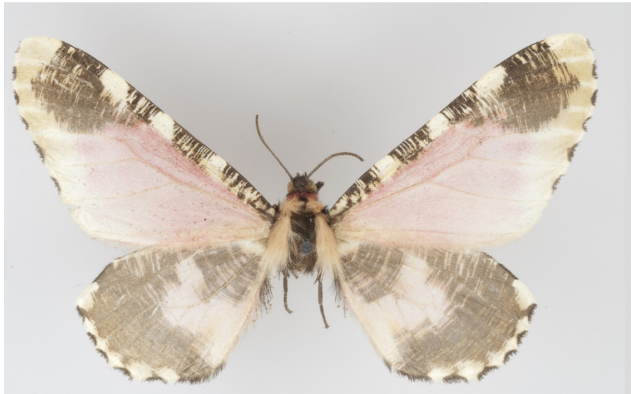

19a paradisea $0^{7}$, holotype of admirabilis
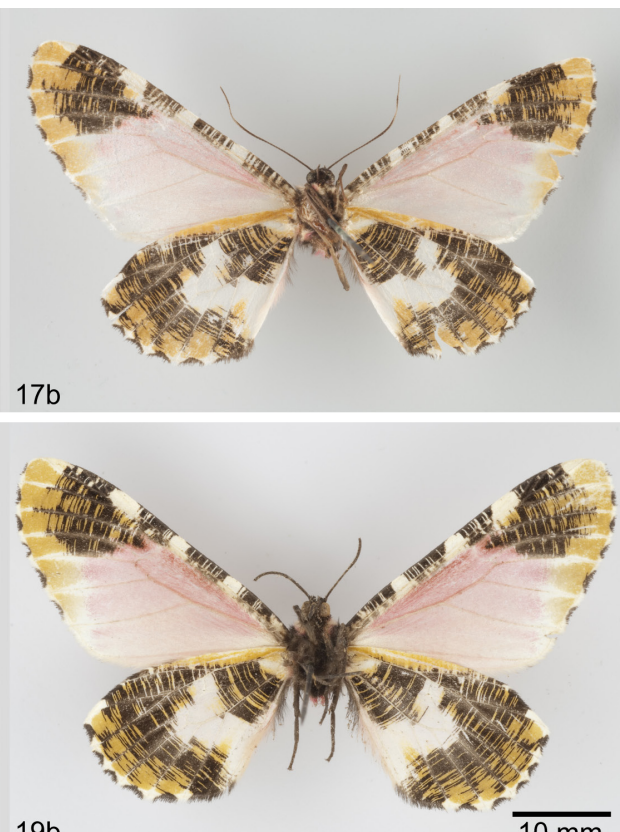

$\overline{10 \mathrm{~mm}}$

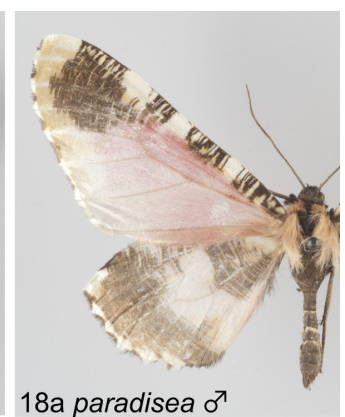

18a paradisea ơ

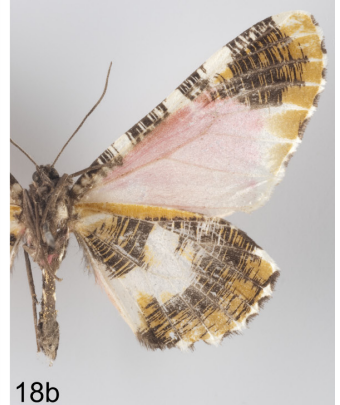

Figs 17-19. Adult moths, $\widehat{\partial} \widehat{\partial}(\mathrm{a}=$ dorsal view; $\mathrm{b}=$ ventral view). 17. Callipia paradisea Thierry-Mieg, 1904, holotype (C-0194). 18. C. paradisea Thierry-Mieg, 1904 (C-0195). 19. C. paradisea ThierryMieg, 1904 (holotype of C. admirabils Warren, 1904) (NHM). 


\section{Other material examined}

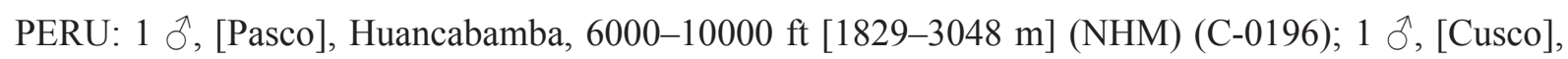
Paucartambo (ZMUC) (C-0063); 2 o 0 [Puno, Carabaya], Agualani, $9000 \mathrm{ft}$ (SMF) (C-0093 with GS402; C-0195 with GS-413, Figs 16, 18).

\section{Description}

As illustrated. The female is unknown.

\section{Distribution}

Eastern Andes of central and south eastern Peru, 1800-3100 m.

\section{Remarks}

Only a few specimens of $C$. paradisea exist in collections. No recently collected material has been available for DNA barcoding and it failed in an old specimen.

\section{The vicinaria group}

This group comprises three species. The moths are on average smaller than members of the other groups. Wings are composed of cream white, ochreous, dark brown and rosé elements. The male valvae have more pronounced spine-like processes on the ventral margin than species of the other groups. The vesicae do not possess cornuti. All species show a pronounced sexual dimorphism that is possibly an apomorphy of the group. The females have a dark grey ground colour with ochreous patterns; the female of C. hausmanni sp. nov. more resembles those of the parrhasiata group. Females of this group are therefore illustrated on a separate plate. Species are distributed from Colombia to central Peru but not further in the south (Fig. 2b).

\section{Callipia vicinaria Dognin, 1913}

Figs 20-23, 30-31, 36, 39

Assigned BIN: BOLD:ACP6822.

\section{Diagnosis}

Callipia vicinaria is one of the smallest known species of Callipia. It is closely related to C. walterfriedlii sp. nov. The spine-like processes on the ventral margin of the valvae are relatively short and the uncus is narrower than in the other closely related species. Other diagnostic characters are discussed in those species. COI-barcode: the minimum observed distance to the genetically most similar species (C. walterfriedlii sp. nov.) is $3.3 \%$.

\section{Type material}

Syntypes (Figs 20,30)

COLOMBIA: 3 Oे, [Tolima], Monte Tolima, 3200 m, [A.H.] Fassl leg. (USNM). One syntype investigated and designated as lectotype: C-0197 with GS-292.

\section{Other material examined}

COLOMBIA: $3 \hat{\jmath} \widehat{\jmath}$, same data as lectotype, Jan. 1910 (NHM, ZMUC) (C-0092; C-0198 with GS-411, Figs 21, 31; C-0199); 1 đ̂, [Tolima], Nevado del Tolima, 2850 m (ZSM) (C-0389, COI sequence 658 bp, BIN, Fig. 22). 


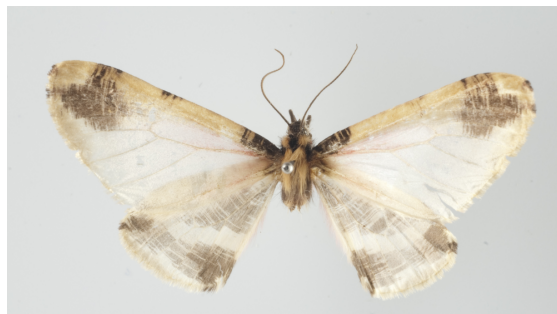

20a vicinaria $\sigma^{7}$, lectotype

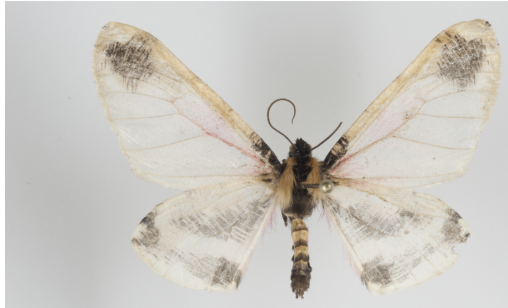

22a vicinaria o ${ }^{7}$

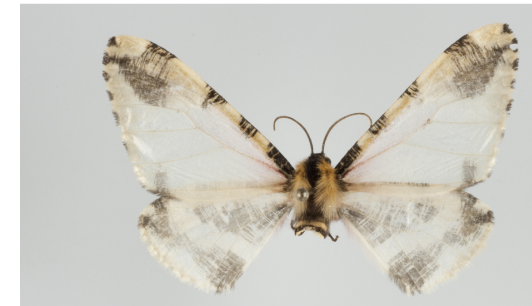

24a walterfriedlii $\sigma^{\top}$, holotype

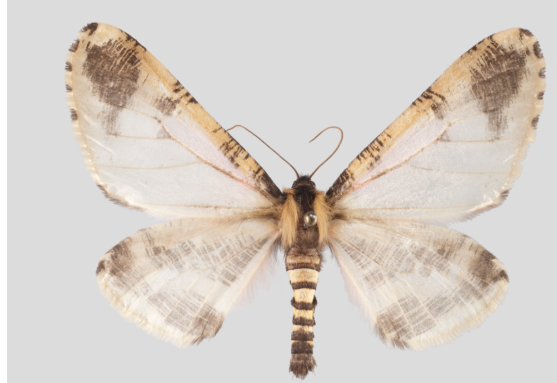

26a walterfriedlii $\sigma^{\top}$, paraype

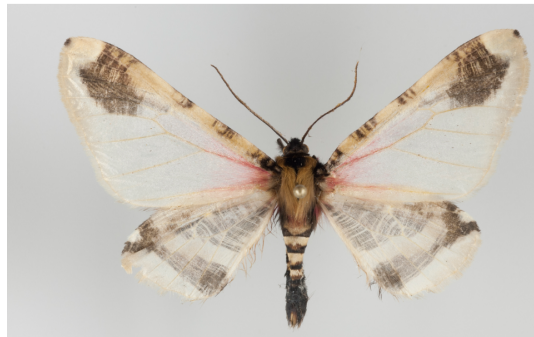

28a hausmanni $\sigma^{7}$, holotype
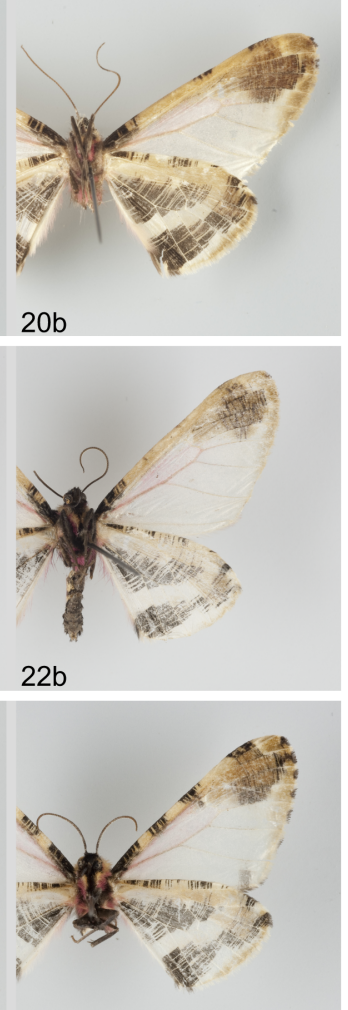

$24 b$
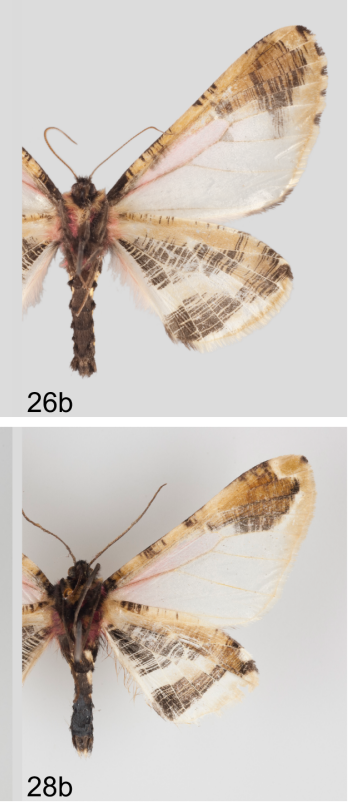

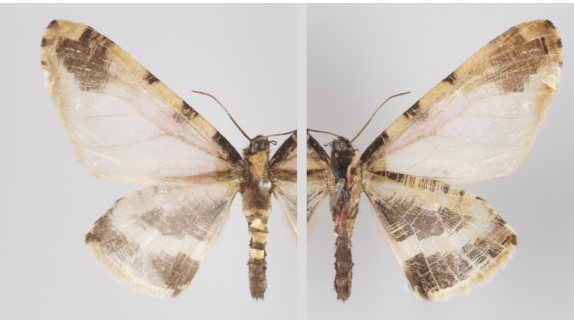

21a vicinaria $0^{T}$

$21 b$
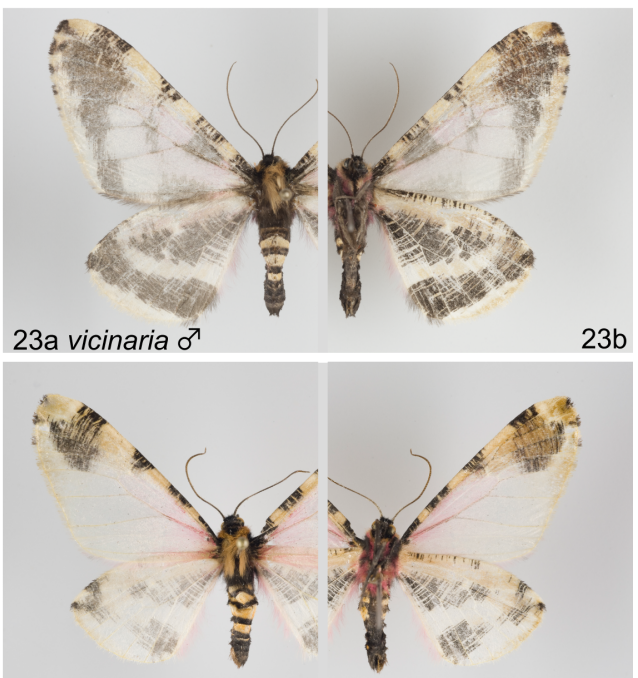

25a walterfriedlii $\sigma^{\top}$, paratype

$25 b$

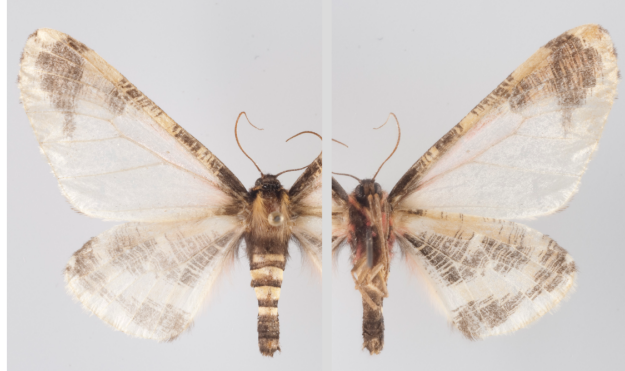

27a walterfriedlii $0^{\top}$, paratype

$27 b$

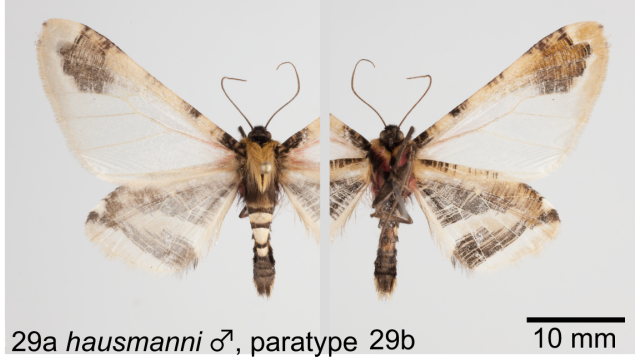

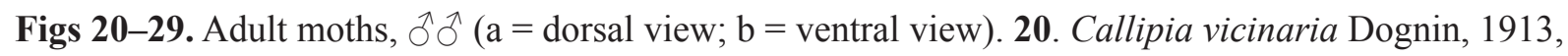
lectotype (C-0197). 21. C. vicinaria Dognin, 1913 (C-0198). 22. C. vicinaria Dognin, 1913 (C-0389, COI data). 23. C. vicinaria Dognin, 1913 (C-0390, COI data). 24. C. walterfriedlii sp. nov., holotype (C-0068, COI data). 25. C. walterfriedlii sp. nov., paratype (ID 22342, COI data). 26. C. walterfriedlii sp. nov., paratype (C-0065, COI data). 27. C. walterfriedlii sp. nov., paratype (C-0207). 28. C. hausmanni sp. nov., holotype (C-0406, COI data). 29. C. hausmanni sp. nov., paratype (C-0413). 

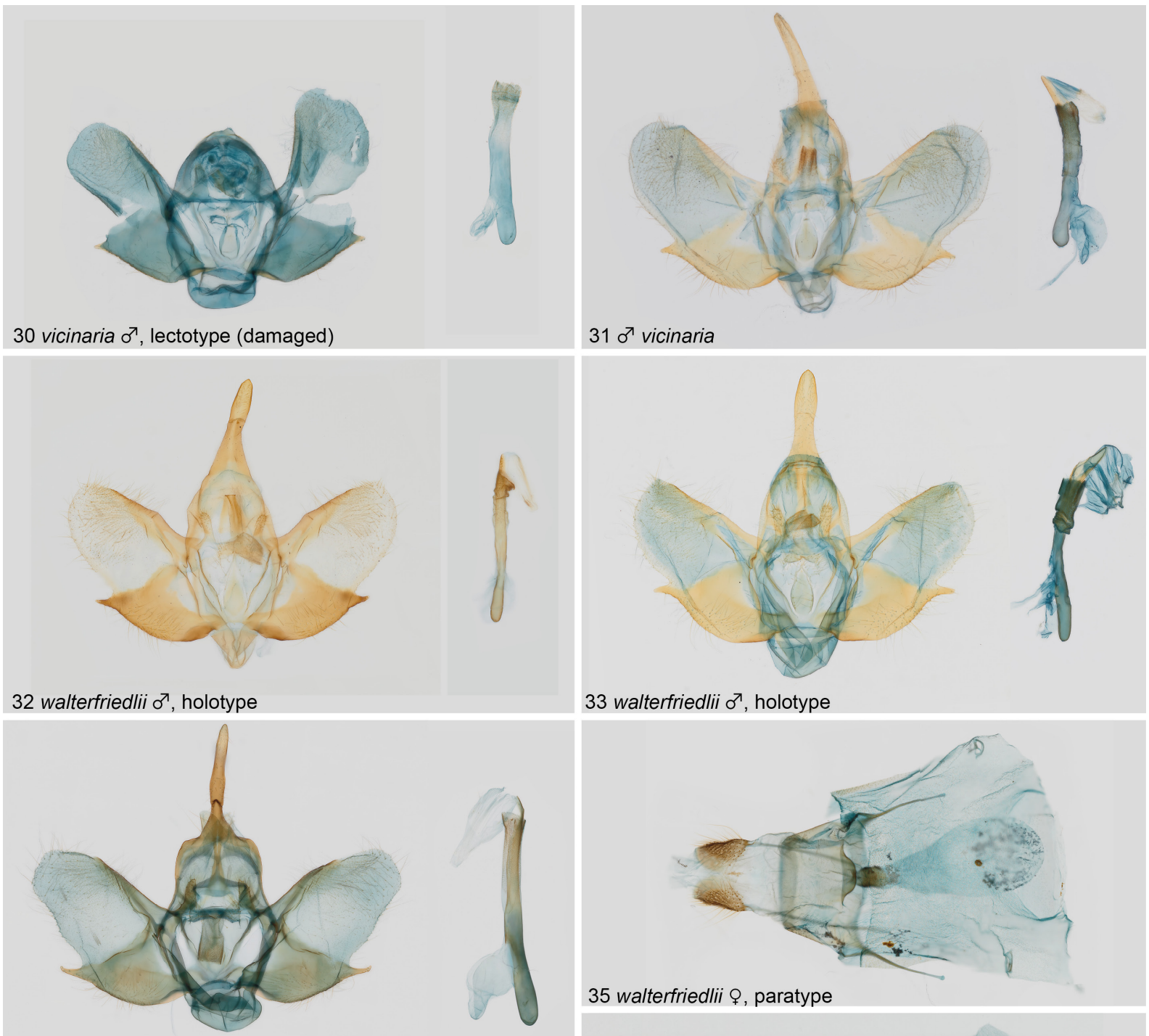

34 hausmanni $\sigma^{7}$, holotype

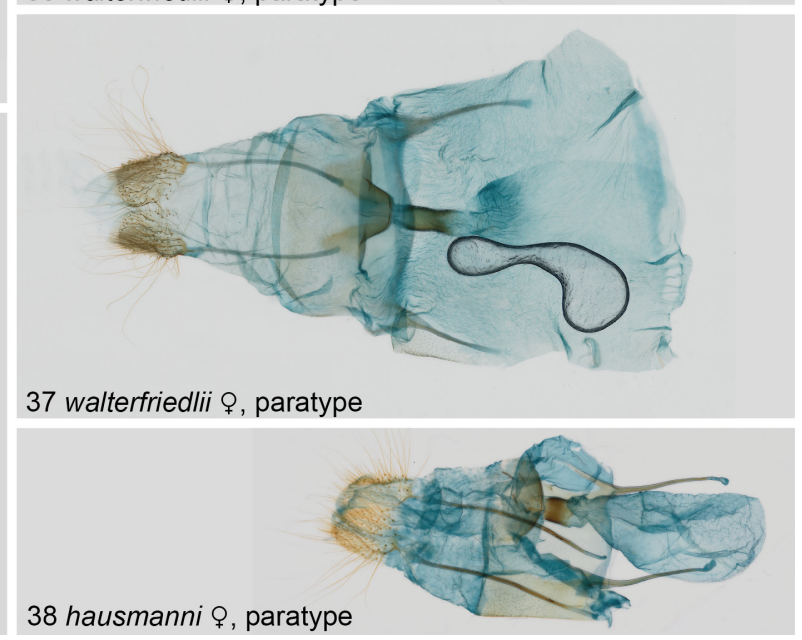

36 vicinaria o

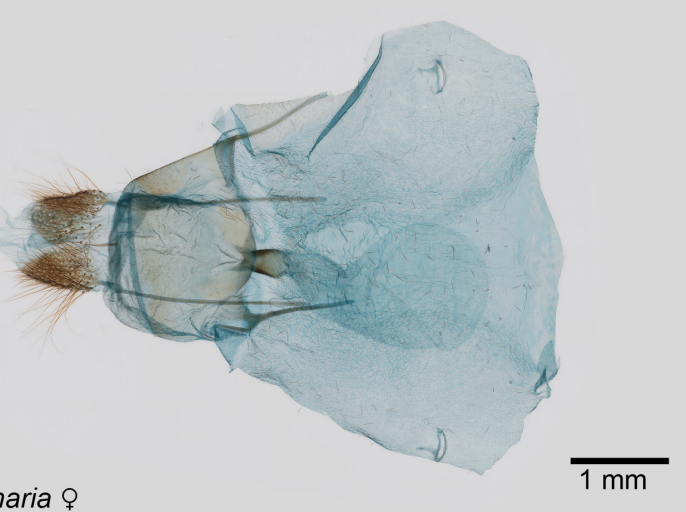

Figs 30-38. Male and female genitalia (left $=$ valves; right $=$ aedeagus). 30. Callipia vicinaria Dognin, 1913, ô, lectotype (C-0197). 31. C. vicinaria Dognin, 1913, ô (C-0198). 32 C. walterfriedlii sp. nov.,

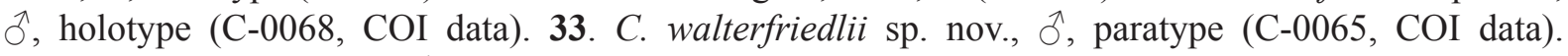
34. C. hausmanni sp. nov., ${ }^{\top}$, holotype (C-0406, COI data). 35. C. walterfriedlii,, , paratype (ID 18948, COI data). 36. C. vicinaria, + (C-0393, COI data). 37. C. walterfriedlii,, , paratype (C-0064, COI data). 38. C. hausmanni sp. nov., + , paratype (C-0407, COI data). 
ECUADOR: 1 đิ, Napo, Papallacta, Rio San Pedro, $3010 \mathrm{~m}, 0.382^{\circ} \mathrm{S}, 78.124^{\circ} \mathrm{W}$ (RCGB) (C-0390, COI sequence 658 bp, BIN, Fig. 23); 1 ô, 1 q, same data as previous (ZSM) (C-0391; C-0392); 1 , same data as previous, but Cuyuja, $2525 \mathrm{~m}, 0.411^{\circ} \mathrm{S}, 78.022^{\circ} \mathrm{W},(\mathrm{ZSM})(\mathrm{C}-0393$ with GS, COI sequence 547 bp (2 bp gap), BIN, Figs 36, 39)

\section{Description}

As illustrated. The extent of dark brown markings on the wings is more extended and pronounced in the Ecuadorian specimens (Fig. 23) than in the males from Colombia (Figs 20-22).

\section{Distribution}

Colombia, eastern Cordillera to north eastern Ecuador, 2500-3200 m.

\section{Remarks}

The female was unillustrated until now.

Callipia walterfriedlii sp. nov. urn:lsid:zoobank.org:act:D1088620-C594-4A25-89F9-3C1F88F1814B

Figs $24-27,32-33,35,37,40-41,132-134$

BIN (holotype): BOLD:AAF5633.

\section{Diagnosis}

Callipia walterfriedlii sp. nov. has a similar wing shape and size like C. vicinaria. Diagnosis from C. hausmanni sp. nov., see there. Males tend to have a more contrasting pattern than C. vicinaria, particularly on the forewing costal area. The white transversal band on the hindwing is broader than in

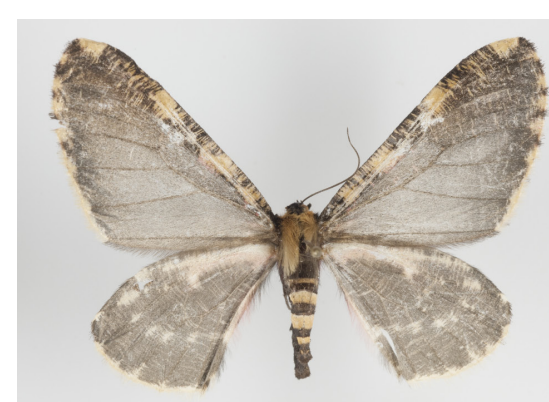

39a vicinaria ㅇ Ecuador

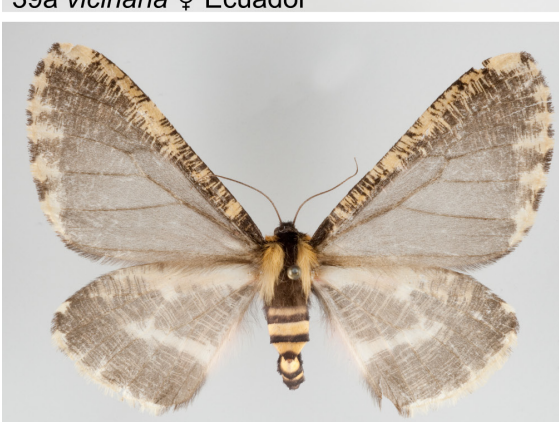

41a walterfriedlii $ᄋ$, paratype

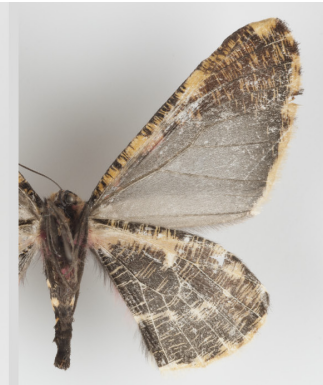

$39 b$

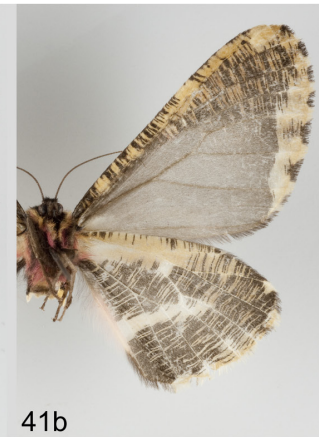

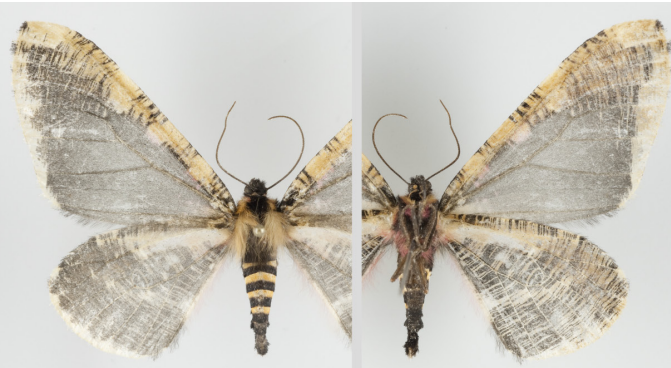

40a walterfriedlii $\$$, paratype $40 \mathrm{~b}$

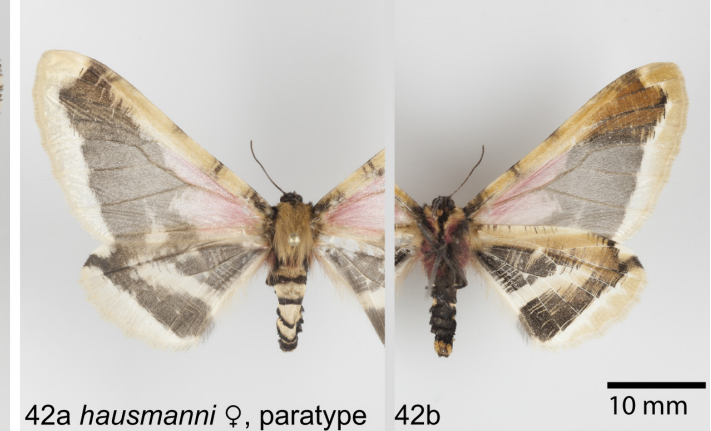

Figs 39-42. Adult moths, $q$ + $(\mathrm{a}=$ dorsal view; $\mathrm{b}=$ ventral view). 39. Callipia vicinaria Dognin, 1913 (C-0393, COI data). 40. C. walterfriedlii sp. nov., paratype (ID 18948, COI data). 41. C. walterfriedlii sp. nov., paratype (C-0064, COI data). 42. C. hausmanni sp. nov., paratype (C-0407, COI data). 
C. vicinaria. The females are very similar, but the extent of the ochreous colour in the forewing is larger. The uncus tends to be broader than in C. vicinaria. COI-barcode: the minimum observed distance to the genetically most similar species (C. vicinaria) is $3.3 \%$.

\section{Etymology}

The species is named in honour of Walter Friedli, Schwarzenburg, Switzerland.

\section{Type material}

Holotype (Figs 24, 32)

ECUADOR: ${ }^{\lambda}$, Loja [province], PN [Parque Nacional] Podocarpus, $04.115^{\circ} \mathrm{S}, 79.171^{\circ} \mathrm{W}, 2950 \mathrm{~m}$, 11 Apr. 2000, S. Rab Green, M. Tapia leg. (AMNH) (C-0068 with GS-398, COI sequence 658 bp, BIN).

\section{Paratypes}

ECUADOR: 1 đo (Figs 27, 33), [Napo], $\mathrm{km} 48$ de la route Salcedo-Rio Mulatos, [ca 1.033 $\mathrm{S}, 78.604^{\circ} \mathrm{W}$ ], 3500 m, 5-6 Jan. 1975, C. Herbulot leg. (ZSM) (C-0065 with GS-421, COI sequence: 315 bp); 1 , same data as previous (ZSM) (C-0064 with GS 419, COI sequence: 124 bp, Figs 37, 41); 4 ô $\hat{0}$, same data as previous, but 7 Jan. [19]75, (ZSM, RCGB) (C-0204 with GS 097; C-0205 with GS-297; C-0207

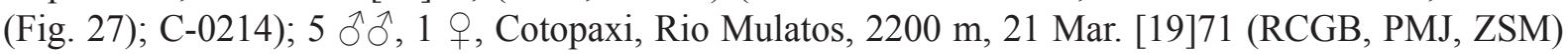

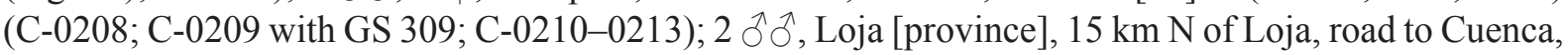
disturbed forest and pastures, $3.825^{\circ} \mathrm{S}, 79.239^{\circ} \mathrm{W}, 2200 \mathrm{~m}, 25$ Mar. 1993, Jan Hillman leg. (CMNH) (C-0066, COI sequence 658 bp, BIN; C-0067 with GS-309, COI sequence 658 bp, BIN); 1 o, Loja Province, Parque Nacional Podocarpus, Cajanuma, 4.114 S, 79.174 W, 2897 m, 26 Mar. 2011, L. Lehner and M. Adams leg. (RCGB) (ID 22342, COI sequence 658 bp, BIN, Fig. 25); $5 \widehat{\delta} \delta^{2}$, Loja [Province], $15 \mathrm{~km} \mathrm{~N}$ of Loja, road to Cuenca, $2200 \mathrm{~m}, 25$ Mar. 1993, Jan Hillmann leg. (AMNH, CMNH, USNM) (C-0200 with GS-273; C-0201-0203; C-0215); 1 o, Loja [Province], Route SaraguroLoja, 13 km N of San Lucas, 3130 m, 4 Mar. 1983, C. Lemaire and P. Thiaucourt leg. (ZSM) (C-0216); 1 , Zamora-Chinchipe, Parque Nacional Podocarpus, Cerro Toledo, $4.386^{\circ} \mathrm{S}, 79.119^{\circ} \mathrm{W}, 2938 \mathrm{~m}$, G. Brehm leg. (RCGB) (ID 18948 with GS, COI sequence 658 bp, BIN, Figs 35, 40); 3 $\partial^{\lambda}$, same data as previous, but $4.380^{\circ} \mathrm{S}, 79.112^{\circ} \mathrm{W}, 3031 \mathrm{~m}$, L. Möckel leg. (RCGB) (ID 18964, COI sequence 658 bp, BIN; ID 48464; ID 48465).

\section{Distribution}

Eastern Andes of Ecuador, 2200-3500 m.

\section{Remarks}

A living female is illustrated in Fig. 133, together with the habitat (Fig. 134).

Callipia hausmanni sp. nov. urn:1sid:zoobank.org:act:2B092DCC-DA6D-420D-BF9E-BAC7073F34D6

Figs 28-29, 34, 38, 42

BIN (holotype): BOLD:AAZ7888.

\section{Diagnosis}

While males of $C$. hausmanni sp. nov. look rather similar as the other three species of the complex, the females are easily distinguished: only females of $C$. hausmanni sp. nov. possess broad cream white margins and a large pale rosy base of the forewing. The males have purely cream white fringes, a relatively intensive rosy basal area of the forewings and a more contrasting pattern of the hindwings than the related species. The male genitalia are characterised by a rectangular shape of the tegumen 
(rounded in the other species) and a narrower uncus. The spine-like processes of the valvae are long and slightly curved. COI-barcode: the minimum observed distance to the genetically most similar species (C. vicinaria) is $5.0 \%$.

\section{Etymology}

The species is named in honour of Axel Hausmann (ZSM), Munich, a leading Geometridae expert in acknowledgment of his support for this study.

\section{Type material}

Holotype (Figs 28, 34)

PERU: đ̂̉, Junín, near Calabaza village, $11.487^{\circ} \mathrm{S}, 74.888^{\circ} \mathrm{W}, 3350 \mathrm{~m}, 27$ Jan. 2011, V. Sinyaev and A. Poleschuk leg. (ZSM) (C-0406 with GS, COI sequence 658 bp, BIN).

\section{Paratypes}

PERU: 1 + , same data as for holotype (ZSM) (C-0407 with GS, 658 bp, BIN, Figs 38, 42); 1 o, same data as for holotype (ZSM) (C-0408); $7 \AA^{\lambda}, 1$ + , same data as for holotype, but $11.493^{\circ} \mathrm{S}, 74.918^{\circ} \mathrm{W}, 3035 \mathrm{~m}$, 29 Jan. 2011 (NHM, PMJ, RCGB, MUSM, ZSM) (C-0409-0412; C-0413, Fig. 29; C-0414-0416).

\section{Description}

As illustrated.

\section{Distribution}

Only known from high elevations in a small area of the Eastern Andes of central Peru, 3000-3400 m.

\section{The constantinaria group}

The six known members of the constantinaria group are easily recognised by their wing patterns: brown coloured with large deep yellow blotches on the forewing. Male valves are overall similar as in the parrhasiata group; the aedeagus is straight and slender without cornuti. The male genitalia within the group are rather similar and appear to be of little use for the diagnosis of species. C. occulta stat. rev. and $C$. hiltae sp. nov. form a cryptic species complex that can reliably only be distinguished by DNA barcoding. Species are distributed from Colombia to northern Argentina (Fig. 2c).

\section{Callipia constantinaria Oberthür, 1881}

Figs 43-44, 59

Assigned BIN: BOLD:AAD6679.

\section{Diagnosis}

The yellow blotch on the forewing is the smallest among all species of the constantinaria group. The male genitalia of the holotype are lost, but male genitalia are very similar among all species in the group. COI-barcode: the minimum observed distance to the genetically most similar species (C. brenemanae) is $3.9 \%$. The most reliable identification method appears to be through DNA barcoding.

\section{Type material}

Holotype (Fig. 43)

PERU: đ̃, [Junín?] Punamarca, 30 Jan. 1873, Constantin Jelski leg. (NHM). The genitalia are lost. 


\section{Other material examined}

PERU: 1 ô, Cusco, Ollantaytambo-Quillabamba R[oa]d, km 158, [ca $13.148^{\circ} \mathrm{S}, 72.513^{\circ} \mathrm{W}$ ], $2945 \mathrm{~m}$ (AMNH) (C-0085 with GS, COI sequence 658 bp, BIN, Figs 44, 59).

\section{Description}

As illustrated. The female is unknown.

\section{Distribution}

Eastern Andes of central and south eastern Peru, $3000 \mathrm{~m}$.

\section{Remarks}

Many museum specimens were identified as $C$. constantinaria but will often actually belong to $C$. occulta stat. rev. and other species. The female is unknown.

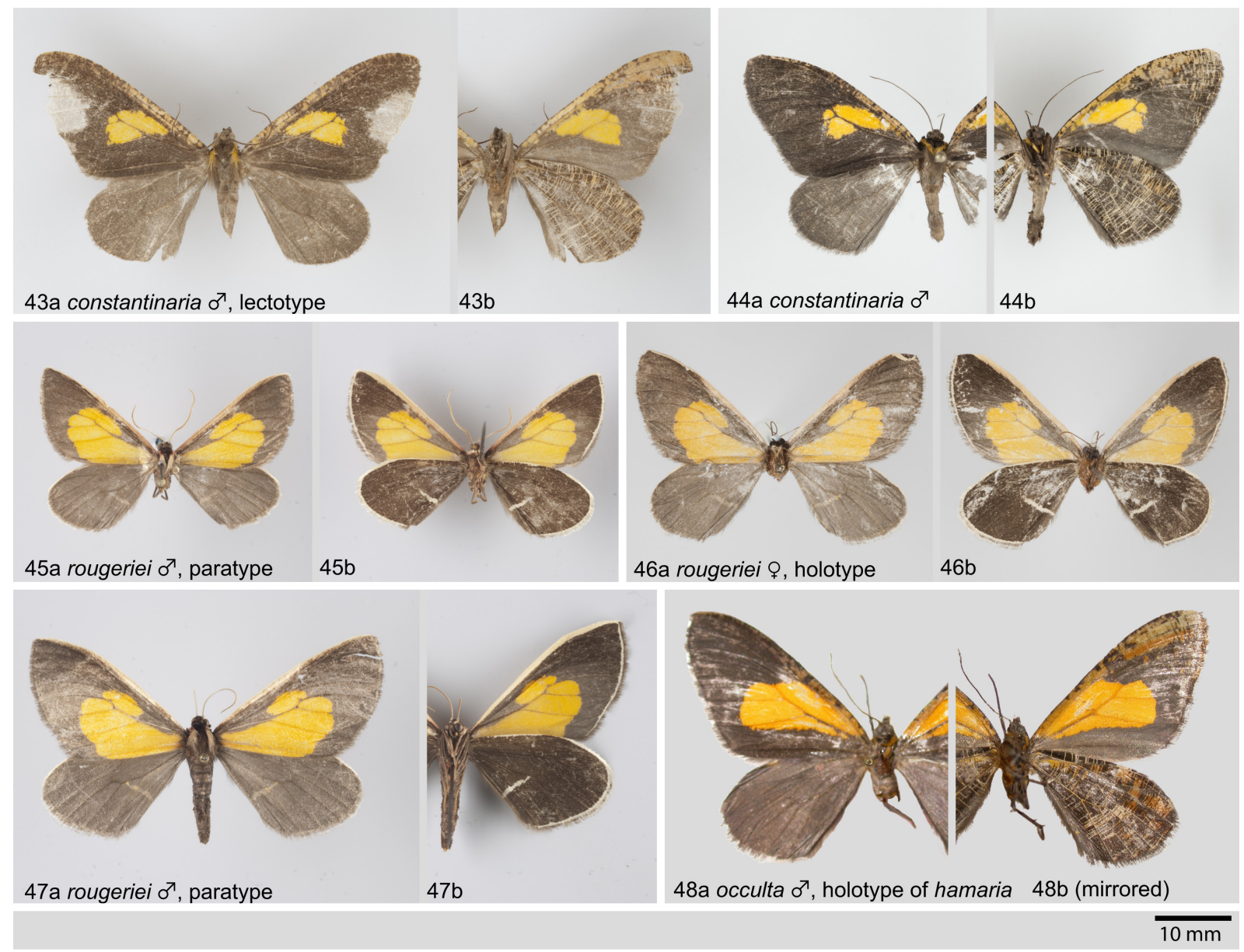

Figs 43-48. Adult moths ( $\mathrm{a}=$ dorsal view; $\mathrm{b}=$ ventral view). 43. Callipia constantinaria Oberthür, 1881, đ, lectotype (NHM). 44. C. constantinaria Oberthür, 1881, ô (C-0085, COI data). 45. C. rougeriei sp. nov., O, paratype (C-0070, COI data). 46. C. rougeriei sp. nov., \&, holotype. 47. C. rougeriei sp. nov., ग, paratype (C-0192, COI data). 48. C. occulta Warren, 1904 stat. rev., ${ }^{\lambda}$, holotype of C. hamaria Sperry, 1951 (AMNH). 


\section{Callipia rougeriei sp. nov. urn:1sid:zoobank.org:act:CB1251FC-59DD-4945-8C06-D1C87834E903}

Figs 45-47, 60, 123

BIN (holotype): BOLD:AAI3930.

\section{Diagnosis}

Unmistakable. Similar as other constantinaria group members, but striae on the underside of the wings completely reduced, and instead with dark brown ground colour (except for the yellow blotch). It has a light ochreous costa on forewing underside and a light ochreous marginal band on the underside of both wings. COI-barcode: the minimum observed distance to the genetically most similar species (C. brenemanae) is $4.7 \%$.

\section{Etymology}

The species is named in honour of Rodolphe Rougerie, MNHN, Paris, France.

\section{Type material}

Holotype (Figs 46, 123)

ARGENTINA: + , Salta, Las Curtiembres, [ca $24.933^{\circ} \mathrm{S}, 65.333^{\circ} \mathrm{W}$ ], 23-24 Feb. 1992, Luis P. Guzman leg. (AMNH) (C-0069 with GS-412, COI sequence 658 bp, BIN).

\section{Paratypes}

ARGENTINA: $2 \overbrace{}^{\widehat{\partial}}$, Jujuy, Yala, [ca $24.183^{\circ} \mathrm{S}, 65.383^{\circ} \mathrm{W}$ ], $1450 \mathrm{~m}, 20$ Feb. 1955, J. Förster leg. (ZSM, RCGB) (C-0070 with GS-301, Figs 45, 60; C-0191); 1 ô, Tucuman, Ciudad Universitaria, 800 m, 20 Feb. [19]59, J.F.G. Clarke leg. (AMNH) (C-0192, COI sequence 658 bp, BIN, Fig. 47); 1 §, Tucuman, R. Schreiter coll. (USNM) (C-0193).

\section{Description}

As illustrated.

\section{Distribution}

Eastern Andes of northern Argentina, 800-1500 m.

Callipia occulta Warren, 1904 stat. rev.

Figs 49-51, 61-62

Callipia hamaria Sperry, 1951: 161. (Fig. 48). Syn. nov.

Assigned BIN: BOLD:AAI3932.

\section{Diagnosis}

Callipia occulta stat. rev. was put into synonymy with C. constantinaria by Parsons et al. (1999), following Prout's catalogue in the British Museum (Natural History). However, the yellow blotch on the forewing is much more restricted in C. constantinaria than in C. occulta stat. rev., moreover, C. constantinaria appears to be a bit smaller than $C$. occulta stat. rev. The comparison of the genitalia is not possible since the final segments of the abdomen are missing in the holotype of $C$. constantinaria. Barcoding revealed two different BINs of $C$. constantinaria-like species from Peru. C. occulta stat. rev. and $C$. hiltae sp. nov. form a cryptic species complex, see $C$. hiltae sp. nov. COI-barcode: the minimum observed distance to the genetically most similar species $(C$. aurata) is $3.4 \%$. 


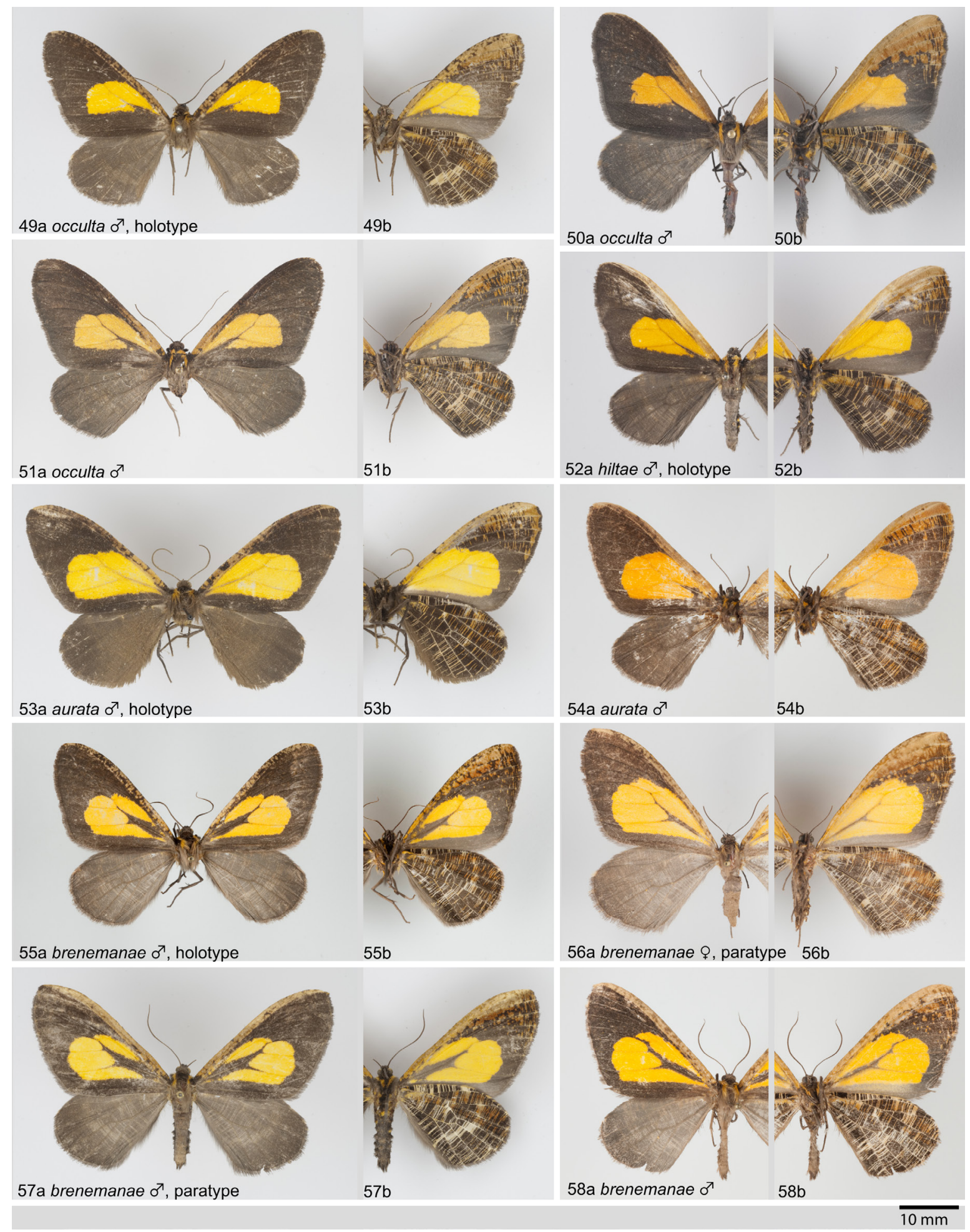

Figs 49-58. Adult moths $(\mathrm{a}=$ dorsal view; $\mathrm{b}=$ ventral view). 49. Callipia occulta Warren, 1904 stat. rev., ô, holotype (NHM). 50. C. occulta Warren, 1904 stat. rev., ô (C-0159, COI data). 51. C. occulta Warren, 1904 stat. rev., $\widehat{\partial}$ (C-0084, COI data). 52. C. hiltae sp. nov., $\widehat{\jmath}$, holotype (C-0153, COI data). 53. C. aurata Warren, 1904, đ, holotype (NHM). 54. C. aurata Warren, 1904, ठ̊ (C-0087, COI data). 55. C. brenemanae Sperry, 1951, ${ }^{\lambda}$, holotype (C-0129). 56. C. brenemanae Sperry, 1951, $q$, paratype (C-0130). 57. C. brenemanae Sperry, 1951, ô, paratype (NHM; C-0131). 58. C. brenemanae Sperry, 1951, $\widehat{o}$ (C-0084, COI data). 

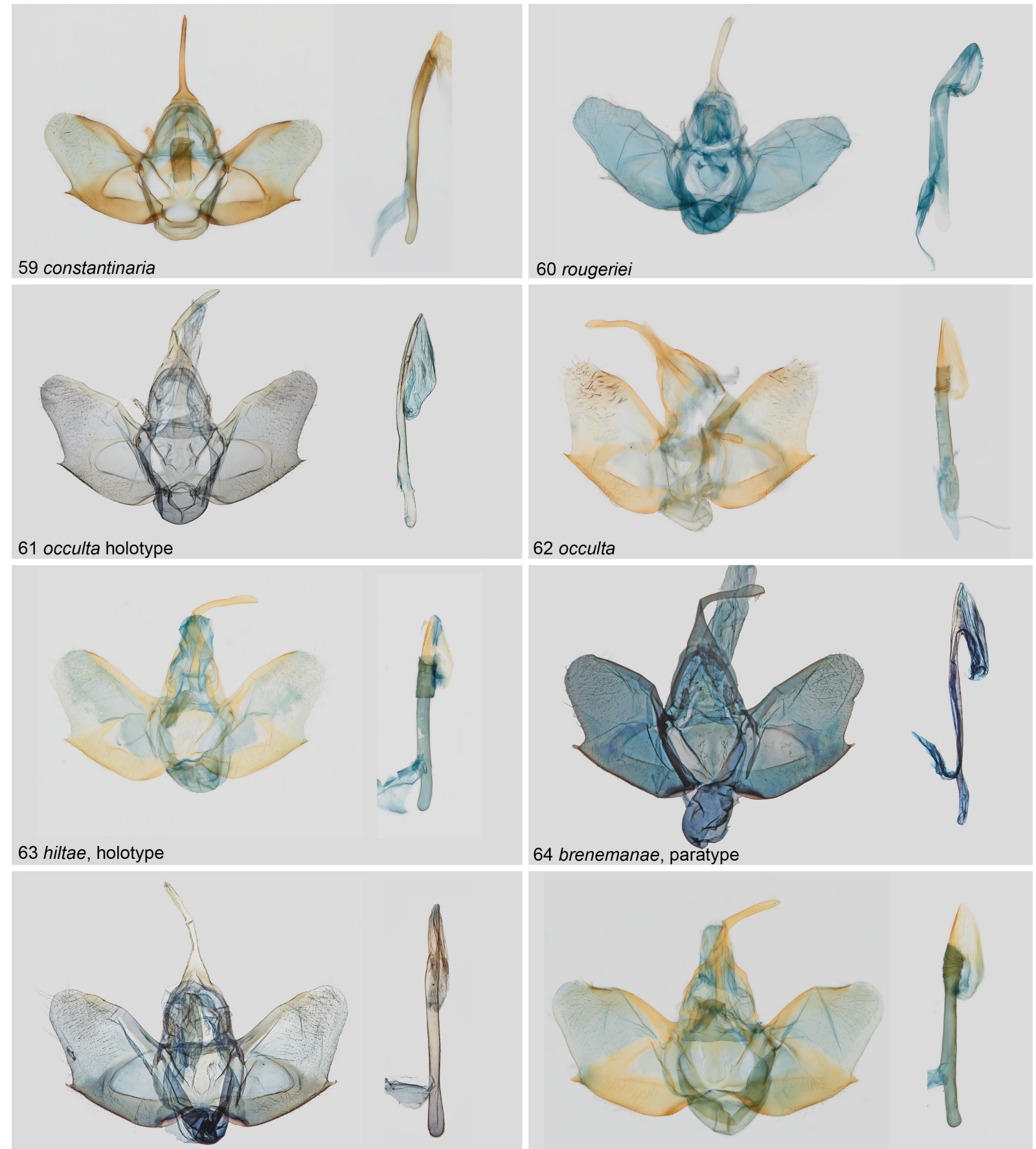

65 aurata, holotype
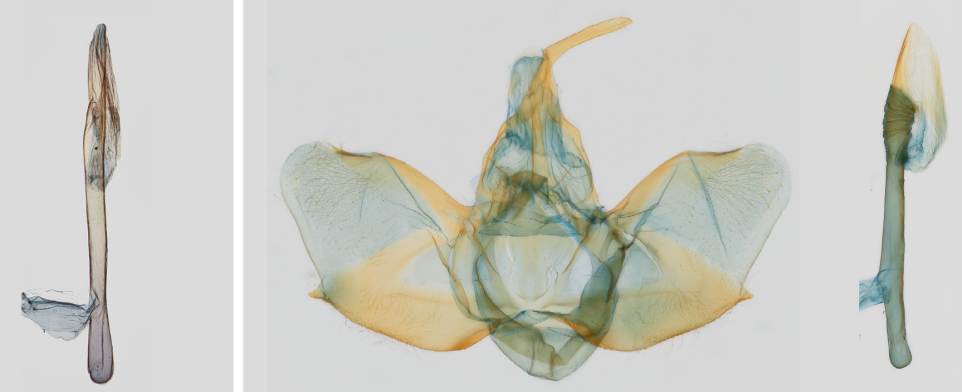

66 aurata

$1 \mathrm{~mm}$

Figs 59-66. Male genitalia (left $=$ valves; right $=$ aedeagus $)$. 59. Callipia constantinaria Oberthür, 1881 (C-0085, COI data). 60. C. rougeriei sp. nov., paratype (C-0070, COI data). 61. C. occulta Warren, 1904 stat. rev., holotype (COI data). 62. C. occulta Warren, 1904 stat. rev., (C-0084, COI data). 63. C. hiltae sp. nov., holotype (C-0153, COI data). 64. C. brenemanae Sperry, 1951, paratype (NHM). 65. C. aurata Warren, 1904, holotype (NHM). 66. C. aurata Warren, 1904 (C-0095, COI data). 


\section{Type material}

Holotype (Figs 49, 61)

PERU: $\widehat{\jmath}$, [no further data available] (NHM).

Other type material (Fig. 48)

PERU: holotype of hamaria Sperry, 1951, [Junín] Satipo, May 1948, P. Paprzycki leg. (AMNH).

\section{Other material examined}

VENEZUELA: no further data (MFN) (C-0107) [doubtful since there are no records from Colombia].

ECUADOR: 1 , Guayaquil (MFN) (C-0106) [doubtful because of the low elevation, far off any other record]; 2 ○ึ, Sucumbios, El Calvario, 2800 m, 7 Aug. 1996, G. Onore, E. Tapia, F. Salazar leg. (CMNH) (C-0082, COI sequence: 658 bp, BIN; C-0115); $15 \hat{\jmath} \widehat{\jmath}$, [Napo] Route Baeza-Lumbaqui au Puente Azuela, 1530 m, 6-7 Feb. 1975, C. Herbulot leg. (ZSM, RCGB) (C-0117-0128, 0157; 0158; 0425); 2 $\widehat{\partial} \widehat{\partial}$, Hacienda San Isidro (ZMUJ) (C-0045; 0116); 1 ठै, Napo, $10 \mathrm{~km}$ E of Papallacta, Hacienda Bosque on road Quito-Baeza, disturbed montane forest, 2600 m, 11 Nov. 1995, Jan Hillman leg. (AMNH) (C0160, COI sequence: 658 bp, BIN); 1 đ, Napo, Cordillera Guacamayos, Cedroyacu Canyon, pristine cedar forest, 2100 m, 8 Aug. 1996, Jan Hillman leg. (AMNH) (C-0161, COI sequence: 407 bp, BIN); 1 万, Napo, Cordillera Huacamayos, Estero Chico, virgin humid forest, $0.617^{\circ} \mathrm{S}, 77.850^{\circ} \mathrm{W}, 2650 \mathrm{~m}, 5 \mathrm{Aug}$. [19]96, J. Hillmann leg. (CMNH) (C-0084 with GS-391, COI sequence: 658 bp, BIN, Figs 50, 62); 1 đ, Napo, Tena, $450 \mathrm{~m}$ [doubtful elevation, not considered for observed distribution], Aug. [19]56, J. Förster

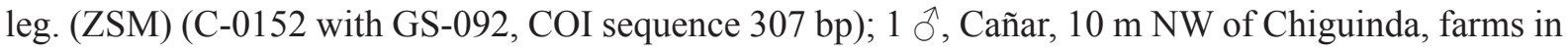
tropical forest, 2000 m, 16 July 1994, Jan Hillman leg. (AMNH) (C-0159, COI sequence: 658 bp, BIN, Fig. 50); 1 ô, Zamora-Chinchipe, $27 \mathrm{~km} \mathrm{NW}$ of Zamora, $3.95^{\circ} \mathrm{S}, 79.05^{\circ} \mathrm{W}, 1550 \mathrm{~m}, 10 \mathrm{Jun}$. 1983, John E. Rawlins leg. (CMNH) (C-0083, COI barcode 307 bp); 1 ô, Zamora-Chinchipe, Reserva Biológica San Francisco, 3.983 S, 79.086 W, 2290 m, 6 May 1999, D. Süßenbach leg. (SMNS) (C-0054 with GS-103, COI sequence: $658 \mathrm{bp}, \mathrm{BIN}) ; 1$ त, same data as previous, but $3.986^{\circ} \mathrm{S}, 79.073^{\circ} \mathrm{W}, 2387 \mathrm{~m}$, 12 May 1999, D. Süßenbach leg. (SMNS) (C-0053, COI sequence: 658 bp, BIN); 1 ô, same data as previous, but Estación Biológica San Francisco, 3.971 S, 79.079 W, 1850 m, 2 July 2007, F. Bodner (RCGB) (C-0081, COI sequence: 658 bp, BIN).

PERU: 2 ठぇ, [Pasco], Quiroz (AMNH) (C-0113; 0155); 1 ภ, [Pasco], near Pozuzo, 1000 m, 6-7 May 1996 m, J. Grados leg (MUSM) (C-0086); 1 ○, [Pasco], Oxapampa (AMNH) (C-0110); 2 $ぇ$, [Pasco] Huancab[amba] (MNHN, ZMF) (C-0100; 0103; 0104); 1 §, [Pasco] Huancab[amba] Pasco de Cerro

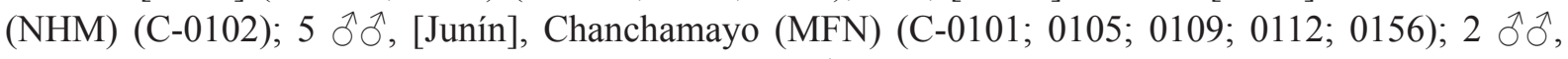
[Junín] Rio Negro, 24 May 1933 (MFN) (C-0108); 1 §, Cusco, Valle de Marcapata (MUSM) (C-0151).

\section{Description}

As illustrated.

\section{Distribution}

Eastern Andes of Ecuador and N and Central Peru, 1500-2800 m.

\section{Remarks}

The taxon C. hamaria, originally described as a form of C. constantinaria by Sperry (1951), actually very closely resembles $C$. occulta stat. rev.; both are from Peru. While Parsons et al.(1999) treated C. hamaria as a junior synonym of $C$. constantinaria, I treat it here as junior synonym of $C$. occulta stat. rev. 


\section{Callipia hiltae sp. nov. urn:1sid:zoobank.org:act:8F8F6F01-D074-4905-9BB6-1E1240895CFC}

Figs 52, 63

BIN (holotype): BOLD:AAD6678.

\section{Diagnosis}

Costa in C. hiltae sp. nov. largely without striae; on the contrary the holotype of $C$. occulta stat. rev. shows such striae as well as most of the 10 successfully DNA-barcoded specimens assigned to C. occulta stat. rev. The extent of the yellow blotch on the forewing appears to be rather variable, and the male genitalia do not offer reliable diagnostic characters either. So far, only two specimens can reliably be assigned to $C$. hiltae sp. nov., but it is possible that the species has a broader distribution. COI-barcode: the minimum observed distance to the genetically most similar species ( $C$. brenemanae) is $5.0 \%$, and it is $5.7 \%$ to $C$. occulta stat. rev.

\section{Etymology}

The species is named in honour of Nadine Hilt, Bayreuth, Germany who carried out a moth diversity study along a disturbance gradient in southern Ecuador.

\section{Type material}

Holotype (Figs 52, 63)

PERU: đ̊, Amazonas, Pomacochas, 2200 m (ZSM) (C-0153 with GS-420, COI sequence 658 bp, BIN).

\section{Paratypes}

PERU: $1 \hat{\jmath}$, same data as for holotype (ZSM) (C-0154, COI sequence $307 \mathrm{bp})$.

\section{Description}

As illustrated. The female is unknown.

\section{Distribution}

Eastern Andes of northern Peru, $2200 \mathrm{~m}$.

\section{Callipia aurata Warren, 1904}

Figs 53-54, 65-66

No assigned BIN, but 307 bp COI fragment.

\section{Diagnosis}

The species with the largest yellow blotch. Only known from Colombia. COI-barcode: the minimum observed distance to the genetically most similar species (C. occulta stat. rev.) is $3.4 \%$.

\section{Type material}

Holotype (Figs 53, 65)

COLOMBIA: $\hat{\jmath}$, [Cauca], Popayan, Lehmann leg. (NHM).

\section{Other material examined}

COLOMBIA: 1 ๙ึ, Cundanimarca, Monterredondo, 1420 m (ZSM) (C-0087, COI sequence 307 bp, Fig. 54);

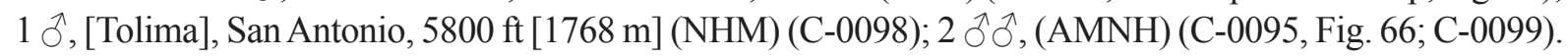




\section{Description}

As illustrated. The female is unknown.

\section{Distribution}

Colombia, western and eastern Cordillera, 1400-1800 m.

\section{Callipia brenemanae Sperry, 1951}

Figs 55-58, 64

Assigned BIN: BOLD:AAF5629.

\section{Diagnosis}

The base of forewing veins $\mathrm{CuA}_{2}, \mathrm{CuA}_{1}$ and often $\mathrm{M}_{3}$ are covered with dark brown scales in brenemanae, particularly at the wing base. Only specimens of $C$. occulta stat. rev. show a similar pattern, but it is weaker and only true for vein $\mathrm{CuA}_{2}$. COI-barcode: the minimum observed distance to the genetically most similar species (C. constantinaria) is $3.9 \%$.

\section{Type material}

Holotype (Fig. 55)

BOLIVIA: ô, [Cochabamba department], Yungas del Palmar, 2000 m, 15 Mar. 1949 (AMNH) (C-0129 with GS-302).

\section{Paratypes}

BOLIVIA: $8 \hat{\jmath} \hat{\jmath}, 4$ + $q$, same locality as holotype [Cochabamba Department], Chapare (AMNH, NHM, private collections), among them one 9 designated as allotype (C-0130 with GS, Fig. 56; and one ${ }^{2}, \mathrm{C}-0131$, Fig. 57). Figure 64 shows the male genitalia of a paratype deposited in the NHM.

\section{Other material examined}

PERU: 3 $\widehat{\jmath}$, [Puno, Oroya] La Oroya and [Puno], Rio Inambari, $3100 \mathrm{ft}$ [945 m] (NHM, SMF) (C0138; 0149; 0150).

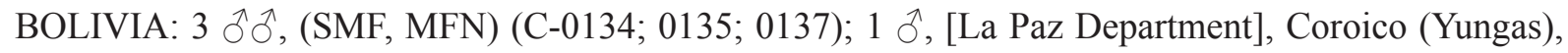

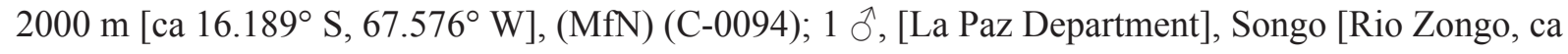
$16.104^{\circ} \mathrm{S}, 68.065^{\circ} \mathrm{W}$ ] (MfN) (C-0139); 1 $^{\circ}$, same locality data as previous, $750 \mathrm{~m}$ (CMNH) (C-0146); 4 ठิં, La Paz Department, northern Yungas, road Ceranavi-Choroico, near Choro (ZSM) (C-04210424); 3 ô $\widehat{\partial}$,[Cochabamba Department], Chapare, San Jocinto, 2800 m (ZSM) (C-0088 with GS-389,

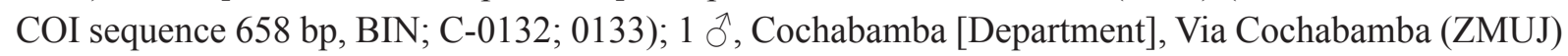
(C-0044, COI sequence 658 bp, BIN); 7 ๙ิ ô, Cochabamba [department] (CMNH, RCGB) (C-0089,

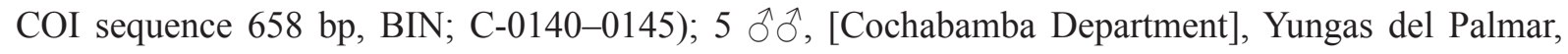
1200-2000 m (AMNH, ZSM) (C-0136; 0147; 0148; 0388; 0426).

\section{Description}

As illustrated. The female is unknown.

\section{Distribution}

Eastern Andes of central to south eastern Peru and central Bolivia, 700-2800 m. 


\section{The parrhasiata group}

This group comprises most species; I acknowledge here 12 taxa at species level with one of them comprising two geographically separated subspecies (C. wojtusiaki sp. nov.). Most species have conspicuous rosy or pink wing bases, but in four species (distributed from central Peru to northern Argentina) the base colour is more intensive and ranges from orange to red. The rosy/pink species are distributed from Colombia to Bolivia. Unlike in the vicinaria group, there is no pronounced sexual dimorphism, but females are considerably larger than males. Unfortunately, the male genitalia only offer very limited diagnostic characters and DNA barcoding in combination with distributional data will sometimes be the only reliable way of distinguishing closely related species.

Callipia parrhasiata Guenée, 1858

Figs $67-69,75,124$

Assigned BIN: BOLD:AAI3927.

\section{Diagnosis}

Probably has the most intense pink colouration of all members of the group, and the most extended dark brown area. Callipia intermedia stat. rev. on forewing upperside with a marginal ochreous blotch, this is only present on the underside in parrhasiata. The male vesica has a series of relatively long cornuti. The cream white margin of the underside of the hindwing is very narrow and considerably less pronounced than in related species. COI-barcode: the minimum observed distance to the genetically most similar species (C. milleri sp. nov. and C. wojtusiaki septentrionalis subsp. nov.) is $4.1 \%$, respectively.

\section{Type material}

Holotype (Fig. 67)

COUNTRY UNKNOWN: + , 'Bengale?' [incorrect locality] (NHM). The last segments of the abdomen are lost. Eggs are visible in the dorsally open abdomen.

\section{Other material examined}

ECUADOR: $2 \precsim ð$, Napo, Route Baeza-Lumbaqui, at Puente Azuela, 1530 m (ZSM) (C-0281; 0282); 1 ग, Napo, Yanayacu Biological Station, $5 \mathrm{~km}$ W of Cosanga on Cosanga-Rio Aliso R[oa]d, $2200 \mathrm{~m}$ (RCGB) (C-0355, COI sequence 307 bp); $1{ }^{\wedge}$, Napo, Papallacta, Cuyuja, $0.421^{\circ} \mathrm{S}, 78.022^{\circ} \mathrm{W}, 2525 \mathrm{~m}$ (ZSM) (C-0405); 1 ${ }^{\lambda}$, Morona-Santiago, W of General Plaza on road from Cuenca (Azuay Province)

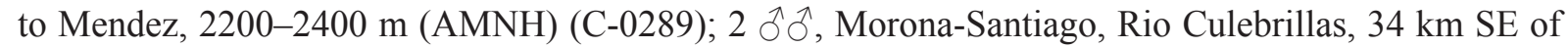
Gualaceo, 2200 m (ZMUJ) (C-0028, COI sequence 658 bp, BIN; C-0288); 6 ふぇ, Morona-Santiago, road Gualaceo-Limon, east, 2200-2450 m (ZMUJ) (C-0038, COI sequence 658 bp, BIN; C-0039 with GS-422, COI sequence 658 bp, BIN, Figs 68, 75; C-0042, COI sequence 658 bp, BIN; C-0283; 0284); 1 q, Morona-Santiago, Road Gualaceo - Plan de Milagro, 2601 m (ZSM) (C-0431 with GS, Figs 69, 124); 1 , same data as previous, but 2157 m (ZSM) (C-0417); 1 đ, Loja [province], R[ou]te SaraguroLoja, $13 \mathrm{~km} \mathrm{~N}$ of San Lucas (?), $3130 \mathrm{~m}$ (ZSM) (C-0286); 15 $\widehat{\partial}$, Zamora-Chinchipe, Reserva Biológica San Francisco, 1850-2677 m (RCGB, SMNS) (ID 6081; 6082; 6084; 18830, 22590; 44631; 48463; C-0025/ID 6083; C-0026 / ID 6085 with GS-284; C-0027/ID 6088 with GS-107; C-0050 / ID 6087; C-0051/ID 55871 with GS-098; C-0052 / ID 25733 with GS-115; C-0080 / ID 17844; C-0287 / ID 6086; several of these with BIN).

\section{Distribution}

Eastern Cordillera of Ecuador, 1500-2700 m. 


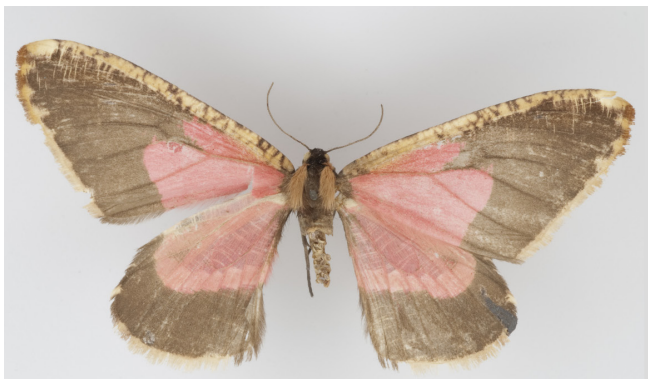

67a parrhasiata 9 , holotype

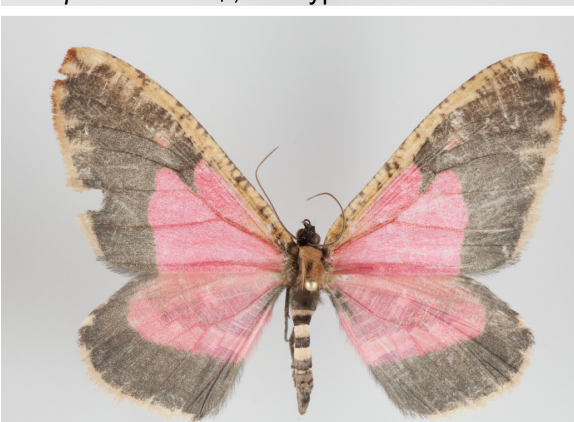

69a parrhasiata $ᄋ$

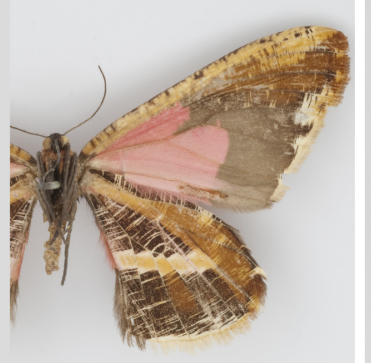

$67 \mathrm{~b}$

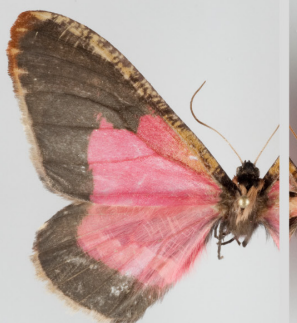

68a parrhasiata ơ

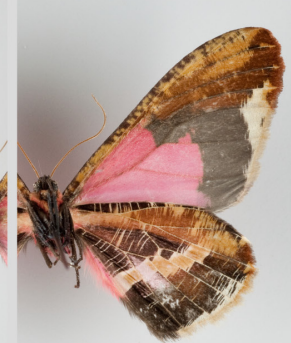

$68 b$
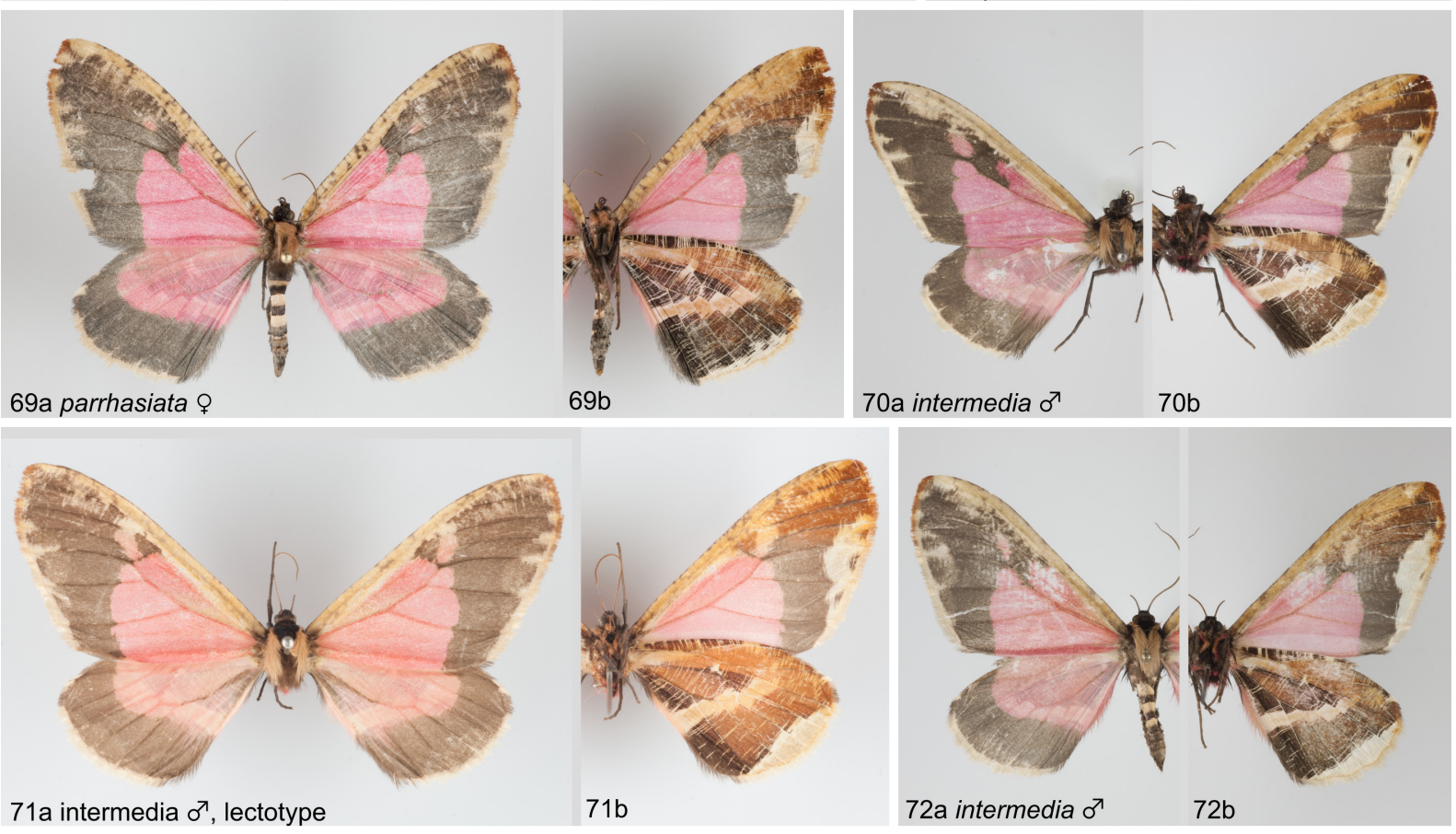

71a intermedia ơ , lectotype $71 \mathrm{~b}$

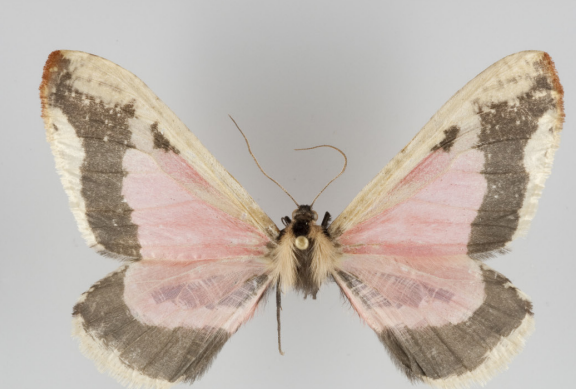

73a karsholti o', holotype

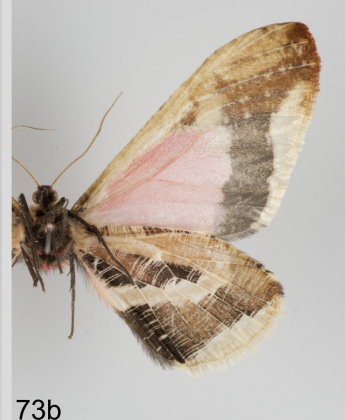

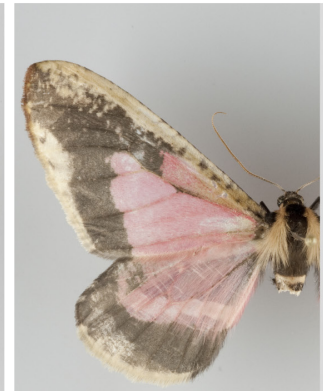

74a karsholti $0^{7}$

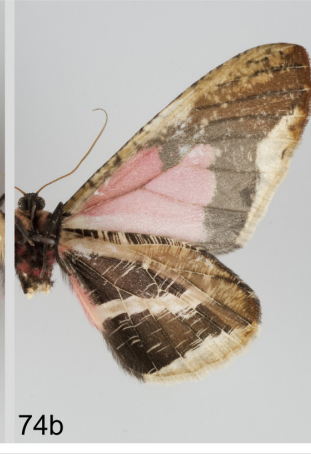

$\overline{10 \mathrm{~mm}}$

Figs 67-74. Adult moths ( $\mathrm{a}=$ dorsal view; $\mathrm{b}=$ ventral view). 67. Callipia parrhasiata Guenée, 1858, ㅇ, holotype (NHM). 68. C. parrhasiata Guenée, 1858, đ̊ (C-0039, COI data). 69. C. parrhasiata Guenée, 1858, + (C-0431). 70. C. intermedia Dognin, 1914 stat. rev., ô (C-0097). 71. C. intermedia Dognin, 1914 stat. rev., đ, lectotype (C-0327). 72. C. intermedia Dognin, 1914 stat. rev., ô (C-0031, COI data). 73. C. karsholti sp. nov., $\partial^{\lambda}$, holotype (C-0033, COI data). 74. C. karsholti sp. nov., $\partial^{\lambda}$ (C-0349, COI data). 
Callipia intermedia Dognin, 1914 stat. rev.

Figs 70-72, 76-78

Assigned BIN: BOLD:AAI3928.

\section{Diagnosis}

Ground colour a little bit less intense, less pink and more reddish than in parrhasiata. The cream white margin of the hindwing underside is broader than in parrhasiata. Light ochreous costal area of forewing
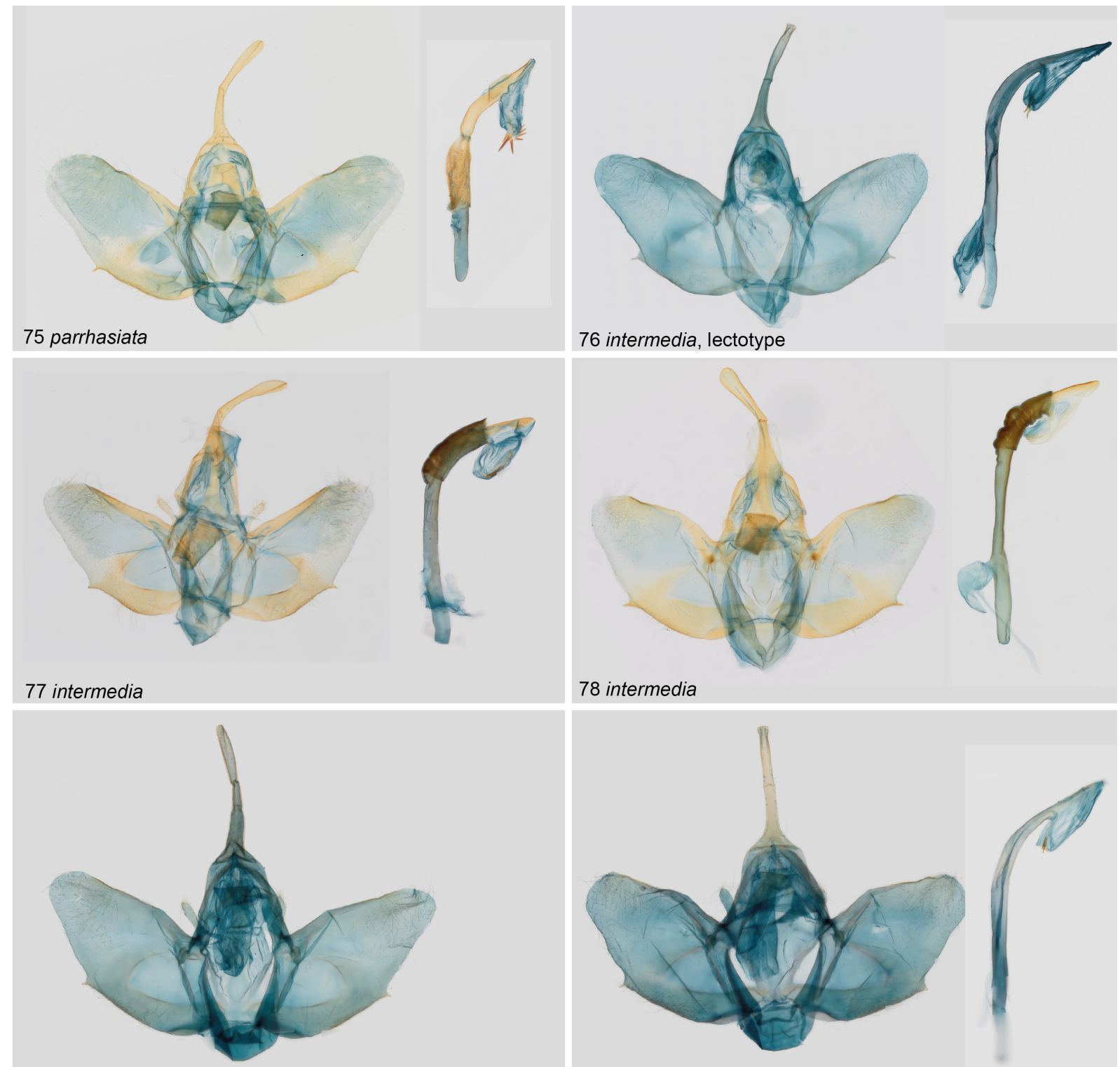

79 karsholti, holotype

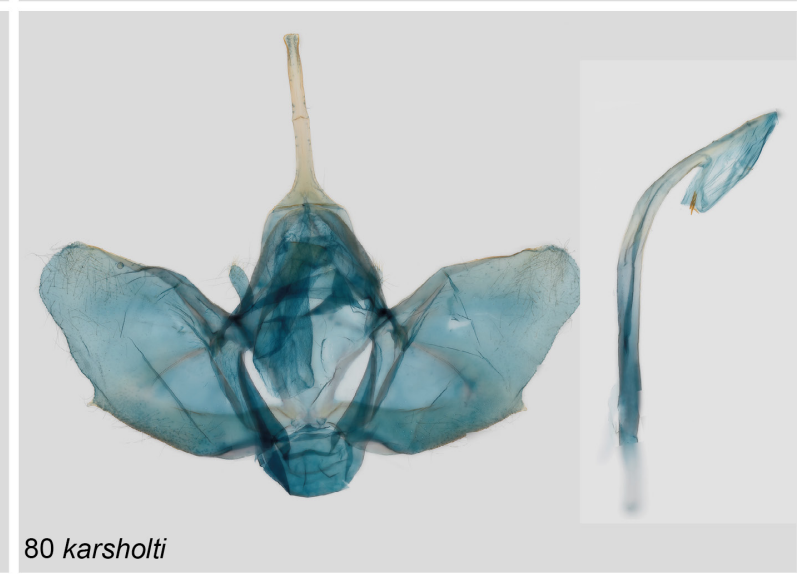

$1 \mathrm{~mm}$

Figs 75-80. Male genitalia (left $=$ valves; right $=$ aedeagus). 75. Callipia parrhasiata Guenée, 1858, $\widehat{\sigma}$ (C-0039, COI data). 76. C. intermedia Dognin, 1914 stat. rev., Ô, lectotype (C-0327). 77. C. intermedia Dognin, 1914 stat. rev., ô (C-0031, COI data). 78. C. intermedia Dognin, 1914 stat. rev., ô (C-0097). 79. C. karsholti sp. nov., $\widehat{\jmath}$, holotype (C-0033, COI data). 80. C. karsholti sp. nov., $\widehat{\partial}$ (C-0349, COI data). 
upperside less extended than in $C$. karsholti sp. nov. COI-barcode: the minimum observed distance to the genetically most similar species ( $C$. jonai sp. nov.) is $2.7 \%$.

\title{
Type material
}

A series of 6 syntypes (males) from Ecuador, Loja; and Peru, [Puno], Carabaya, Limbari [correct: Limbani], and Agualani (USNM). These six specimens are not conspecific; the two Ecuadorian specimens (C-0019; C-0357) are assigned to C. wojtusiaki sp. nov. (see there). Specimens from Limbani were indicated by Dognin (1914) as 'type', and therefore a specimen from this locality is selected as lectotype (C-0327 with GS-296, Figs 71, 76; the other C-0329). Two specimens are from from Agualani (C-0328 with GS-283; C-0330).

\section{Other material examined}

PERU: $2 \widehat{\partial}$ ô, Cusco, Ollantaytambo-Quillabamba R[oa]d, km 158, 2945 m (AMNH) (C-0030 with GS-393, COI barcode 615 bp, BIN; C-0059, COI barcode 658 bp, BIN); 1 ô, Cusco, Valle de

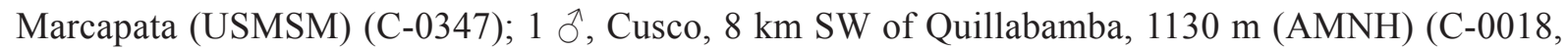
COI sequence 464 bp, BIN); 2 $\widehat{\jmath}$, [Cusco], Paucartambo (ZMUC) (C-0097 with GS-406, Figs 70, 78; C-0341); $3 \hat{\jmath}$, Madre de Dios, Tambopata Preserve, Explorer's Inn, $200 \mathrm{~m}$ [probably wrong locality/elevation, not considered in distribution] (AMNH) (C-0031 with GS 407, COI sequence 658 bp, BIN, Figs 72, 77; C-0350; C-0351, COI sequence 307 bp); 1 ô, Puno, 5 km E of Limbani, 3000 m

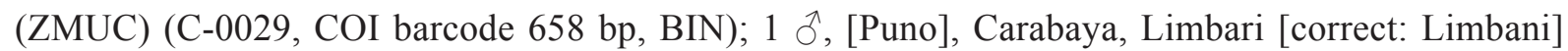
(MHNH) (C-0348); 15 §ิð, [Puno], Carabaya, Agualani, 9000 ft (AMNH, PMJ, RCGB, SMF, ZSM) (C-0331-0346).

\section{Distribution}

Eastern Andes of south eastern Peru, 1100-3000 m.

\section{Remarks}

The species was described as subspecies of $C$. parrhasiata, but is clearly an independant species. The six syntypes belong to two different taxa (see above).

\author{
Callipia karsholti sp. nov. \\ urn:1sid:zoobank.org:act:0C08D964-2F7A-4B21-B0C9-F3AABF0A2476
}

Figs $73-74,79-80$

BIN (holotype): BOLD:ABY4709.

\section{Diagnosis}

Most similar to $C$. intermedia stat. rev. (sympatric distribution), but ground colour light rosy with an extended light ochreous costal area on the forewing upperside. Similarly as in C. intermedia stat. rev., but different from C. parrhasiata, male aedeagus with a few small cornuti. COI-barcode: the minimum observed distance to the genetically most similar species (C. intermedia stat. rev.) is $2.8 \%$.

\section{Etymology}

The species is named in honour of Ole Karsholt (ZMUC), Copenhagen, Denmark, who collected the type specimens in Peru. 


\section{Type material}

Holotype (Figs 73, 79)

PERU: Ô, Puno, $5 \mathrm{~km}$ E of Limbani, $3000 \mathrm{~m}, 14.125^{\circ} \mathrm{S}, 69.682^{\circ} \mathrm{W}, 28$ Mar. 1987, O. Karsholt leg. (ZMUC) (C-0033 with GS-304, COI sequence 615 bp, BIN).

\section{Paratypes}

PERU: $1 \partial^{\top}$, Cusco, Cosñipata, $13.140^{\circ} \mathrm{S}, 71.584^{\circ} \mathrm{W}, 2240$ m, 23. Aug. 2016, D. Bolt leg. (PMJ) (PeGeo-1162); 1 § , Cusco, Cosñipata, $13.140^{\circ} \mathrm{S}, 71.584^{\circ} \mathrm{W}, 2250 \mathrm{~m}, 23$. Aug. 2016, M. Nuß leg. (MTD) (C-0477, Pe-Geo-1141).

\section{Other material examined}

PERU: 1 Oे, Huánuco, 15: 25 km NE of Huánuco, Cordillera Carpish, Pattytrail, 2500 m, 8-10 Nov. 1987, O. Karsholt leg. (ZMUC) (C-0349 with GS-323, COI sequence 251 bp, Figs 74, 80). Because of the different sampling location in central Peru, the assignment of this specimens to karsholti sp. nov. is provisional until more material can be examined.

\section{Description}

As illustrated.

\section{Distribution}

Eastern Andes of south eastern Peru, 2240-3000 m.

\section{Callipia rosetta Thierry-Mieg, 1904}

Figs 81-85, 88-92, 131-132

Callipia languescens Warren, 1904: 539 (confirmed junior synonym of rosetta, see Parsons et al. (1999) (Figs 82, 89)

Assigned BIN: BOLD:AAI3925.

\section{Diagnosis}

Callipia rosetta is usually a rather small species. Some large specimens are provisionally included in C. rosetta (same BIN), but might turn out as different species if more data on the life history of the taxa become available. The spine-like process on the ventral margin of the valvae is well developed and larger than in augustae sp. nov. COI-barcode: the minimum observed distance to the genetically most similar (but not similar looking) species (C. fulvida) is $4.4 \%$.

\section{Type material}

Originally described with two male as syntypes from Peru, [Pasco], Huancabamba, 1903 (USNM). One of these males is designated as lectotype (C-0290 with GS-286, Figs 81, 88).

PERU: Õ, holotype of C. languescens Warren, 1904 (confirmed junior synonym of rosetta), [Pasco], Huancabamba, Cerro de Pasco, [E.] Böttger leg. (NHM) (Figs 82, 89).

\section{Other material examined}

ECUADOR: $9 \widehat{\jmath} \widehat{\jmath}$, Napo, Cordillera Huacamayos, Rio Cedroyacu, $00^{\circ} 37^{\prime} \mathrm{S}, 77^{\circ} 51^{\prime} \mathrm{W}$ [incorrect coordinates], 2100 m, 7 Aug. 1996, Jan Hillman leg. (CMNH, NHM, ZSM) (C-0010 with GS-312, COI sequence 556 bp, BIN; C-0011 with GS-416, COI sequence 603 bp, BIN, Figs 83, 92; C-0274 
with GS-287; C-0275-0280); 2 $\widehat{\partial}$ के, Loja province, Parque Nacional Podocarpus, Cajanuma, $04.114^{\circ} \mathrm{S}$, $79.175^{\circ}$ W, 2897 m, 26 Mar. 2011, L. Lehner and M. Adams leg. (PMJ, RCGB) (ID 22359 with GS, COI sequence 658 bp, BIN, Figs 84, 90; ID 22362 with GS, COI sequence 658 bp, BIN, Figs 85, 91); $1 \hat{\jmath}$, same data as previous, but 2916 m, G. Brehm leg. (RCGB) (ID 22316, COI sequence 658

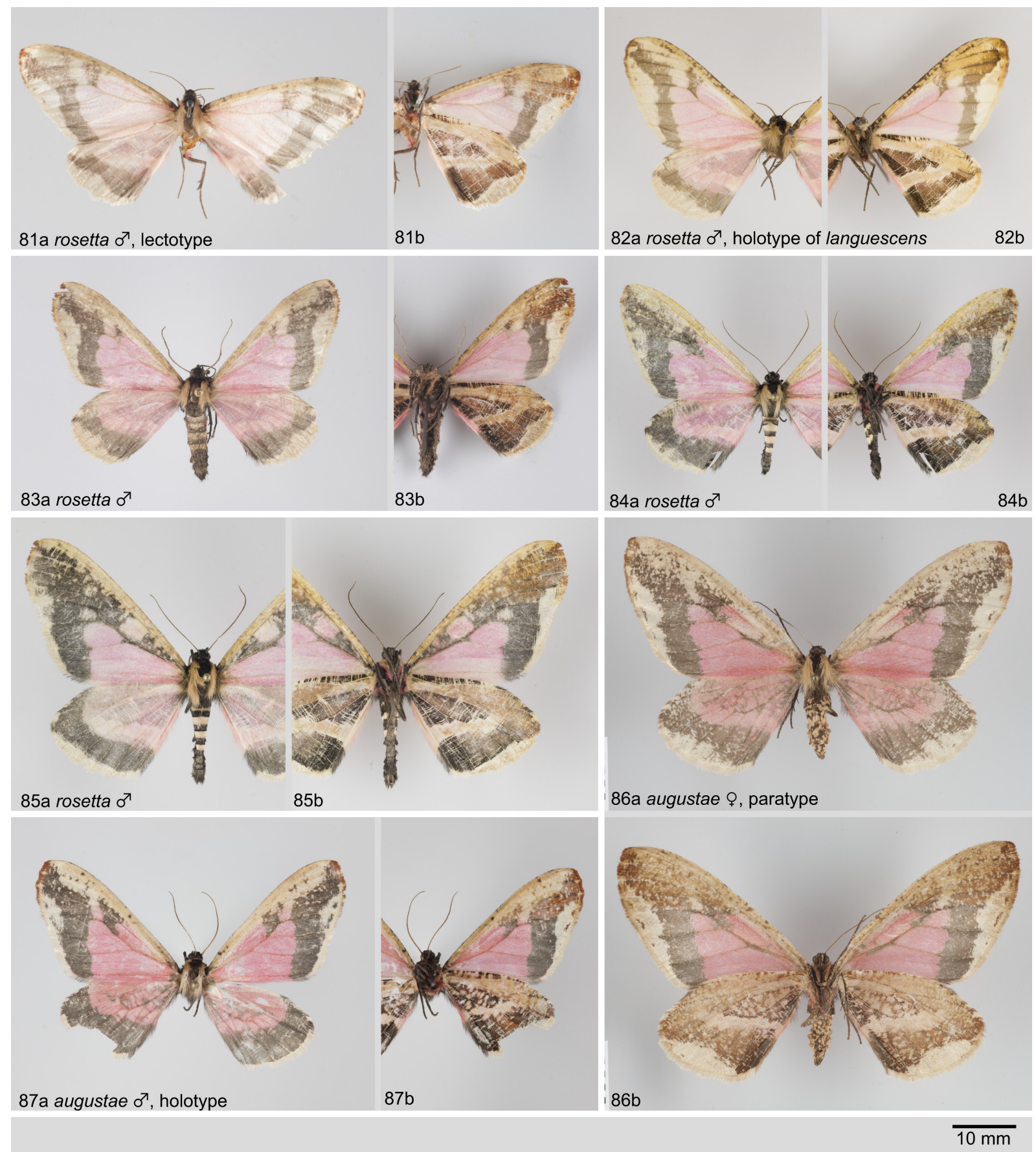

Figs 81-87. Adult moths ( $\mathrm{a}=$ dorsal view; $\mathrm{b}=$ ventral view). 81. Callipia rosetta Thierry-Mieg, 1904, $\mathrm{O}^{\text {, }}$ lectotype (C-0290). 82. C. rosetta Thierry-Mieg, 1904, Ô, holotype of languescens Warren, 1904 (NHM). 83. C. rosetta Thierry-Mieg, 1904, ô (C-0011, COI data). 84. C. rosetta Thierry-Mieg, 1904, $\sigma^{\lambda}$ (ID 22359, COI data). 85. C. rosetta Thierry-Mieg, 1904, § (ID 22362, COI data). 86. C. augustae sp. nov., ,, paratype (C-0432). 87. C. augustae sp. nov., ô, holotype (C-0056, COI data). 


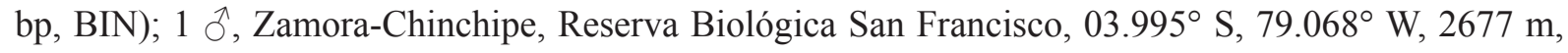
31 Mar. 2011, G. Brehm leg. (RCGB) (ID 22580).

PERU: 1 đ, [Huánuco or San Martín or western Loreto] Huallaga (USNM) (C-0292); 1 đ, [Pasco],

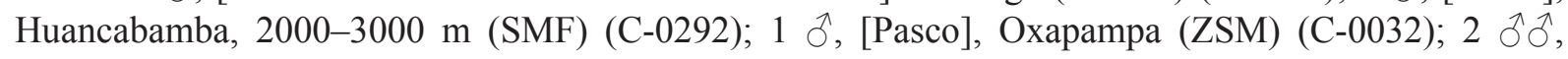
[Puno], Carabaya, Agualani (SMF, USNM) (C-0293 with GS-305, C-0296).

\section{Description}

Male as illustrated. Female unknown.
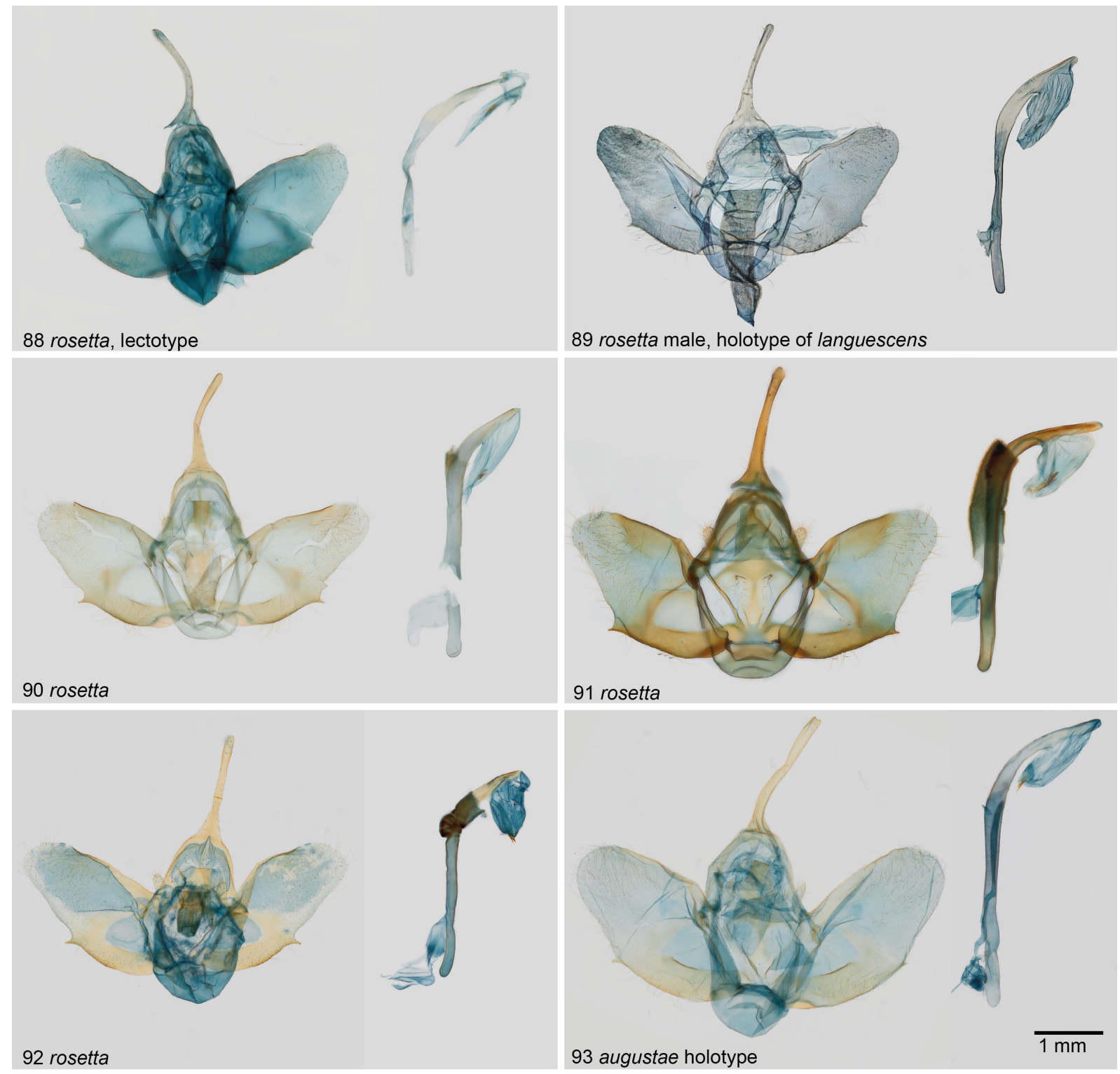

Figs 88-93. Male genitalia (left = valves; right = aedeagus). 88. Callipia rosetta Thierry-Mieg, 1904, ô, lectotype (C-0290). 89. C. rosetta Thierry-Mieg, 1904 (holotype of C. languescens Warren, 1904), ô, holotype (NHM). 90. C. rosetta Thierry-Mieg, 1904, $\partial^{\top}$ (ID 22359, COI data). 91. C. rosetta ThierryMieg, 1904, đิ (ID 22362, COI data). 92. C. rosetta Thierry-Mieg, 1904, § (C-0011, COI data). 93. C. augustae sp. nov., Ô, holotype (C-0056, COI data). 


\section{Distribution}

Eastern Cordillera of Ecuador and Peru, 2100-3000 m.

\section{Remarks}

A living male is illustrated in Fig. 131 together with its habitat in Ecuador (Fig. 132).

Callipia augustae sp. nov. urn:1sid:zoobank.org:act:53BC4DD0-6174-42B0-B754-0B244C9F3FA7

Figs $86-87,93,125,135-137$

Assigned BIN: BOLD:AAI3929.

\section{Diagnosis}

Callipia augustae sp. nov. is unique in having spotted wing pattern pattern elements, i.e., the fine light ochreous striae that are found in most other species of Callipia are mostly widened to small spots. The spine-like processes on the ventral margin of the valvae are very small. COI-barcode: the minimum observed distance to the genetically most similar (but not similar looking) species (C. flagrans) is $2.6 \%$.

\section{Etymology}

The species is named in honour of Augusta Albrecht, Friedrichshafen, Germany.

\section{Type material}

Holotype (Figs 87, 93)

ECUADOR: ${ }^{\lambda}$, Zamora-Chinchipe, Reserva Biológica San Francisco, $1921 \mathrm{~m}, 03.978^{\circ} \mathrm{S}, 79.083^{\circ} \mathrm{W}$, N. Hilt and C. Ramenda leg. (PMJ) (ID 25732 / C-0056 with GS-316, COI sequence 658 bp, BIN).

\section{Paratypes}

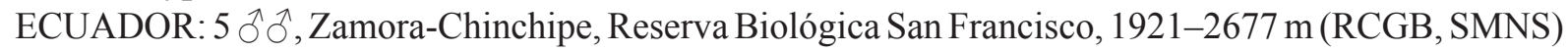
(C-0055 with GS-102, COI sequence 658 bp, BIN; C-0057 with GS R. Trusch 480, COI sequence 658 bp, BIN; C-0058 with GS-100, COI sequence 658 bp, BIN; ID 44632; ID 44633).

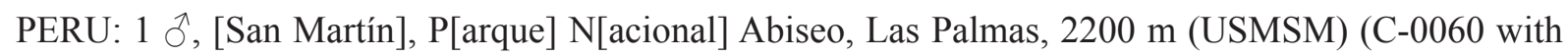

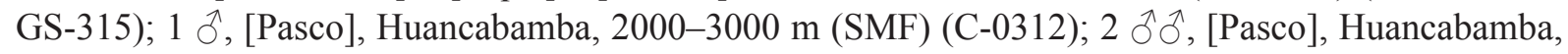
Cerro de Pasco, 6-10000 ft (NHM) (C-0295 with GS-281; C-0311); 1 §ิ, [Junín], Chanchamayo (USNM) (C-0315 with GS-107); 1 $\widehat{\partial}$, [Junín], Chanchamayo, La Merced (AMNH) (C-0303); $2 \hat{\jmath} \widehat{\partial}$, [Ayacucho], Apurímac, Rio Piene (AMNH) (C-0305; 0306); 1 đె, [Cusco], Paucartambo (ZMUC) (C-0302 with

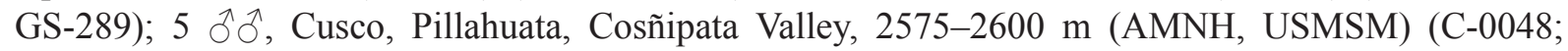
0049; 0162; 0169; 0170); 1 స, [Cusco], Cosñipata, 2200 m (ZSM) (C-0299); 1 ○, Cusco, Cosñipata, $13.177^{\circ} \mathrm{S}, 71.581^{\circ} \mathrm{W}, 2680 \mathrm{~m}, 21$. Aug. 2016, D. Bolt leg. (ID Pe-Geo-0128, C-0474, COI sequence 658 bp, BIN); $1 \jmath^{\Uparrow}$, Cusco, Cosñipata, 13.141 ${ }^{\circ} \mathrm{S}, 71.585^{\circ} \mathrm{W}, 2250 \mathrm{~m}, 23$. Aug. 16, M. Nuß leg. (PMJ) (Pe-Geo-1142, C-0478, COI sequence 658 bp, BIN); 1 ㅇ, Cusco, Cosñipata, $13.140^{\circ} \mathrm{S}, 71.584^{\circ} \mathrm{W}$, 2240 m, 23. Aug. 2016, D. Bolt leg. (PMJ) (Pe-Geo-1143, C-0479, COI sequence 658 bp, BIN); 1 ठ, Cusco, Cosñipata, 13.179 ${ }^{\circ}$ S, $71.582^{\circ}$ W, 2770 m, 21. Aug. 2016, M. Nuß leg. (MTD) (Pe-Geo-1153); $1 \mathrm{O}^{\top}$, Cusco, Cosñipata, $13.178^{\circ} \mathrm{S}, 71.582^{\circ} \mathrm{W}, 2770 \mathrm{~m}, 21$. Aug. 2016, G. Brehm leg. (MTD) (Pe-

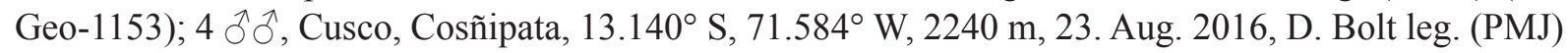

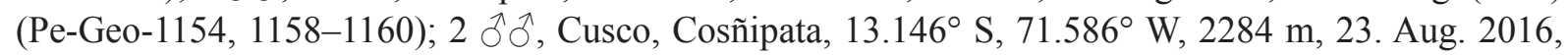

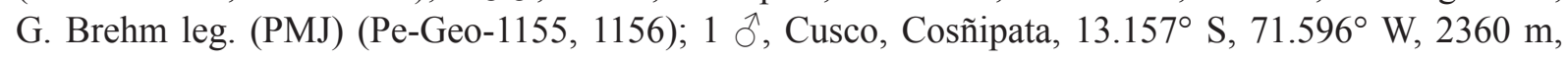
25. Aug. 2016, J. Grados leg. (PMJ) (Pe-Geo-1161); 1 §, [Cusco], Torontoy, 7000 ft (USNM) (C-0304); 
$3 \widehat{\partial} \widehat{\partial}$, [Puno], Carabaya, Rio Huacamaya (USNM) (C-0308-0310); $1 \hat{\jmath}$, [Puno], Carabaya, Oconeque (USNM) (C-0307); 1 male Cusco, Valle de Marcapata (USMSM) (C-0061).

BOLIVIA: $1 \hat{\jmath}$, [La Paz Department], Rio Tanampaya, [ca $16.30^{\circ} \mathrm{S}, 67.33^{\circ} \mathrm{W}$ ] (MfN) (C-0320);

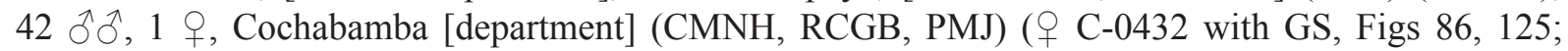
C-0326); 4 ô $\widehat{\partial}$, Cochabamba [Department], Chapare, Paracti, 2200 m (AMNH) (C-0062 with GS-099,

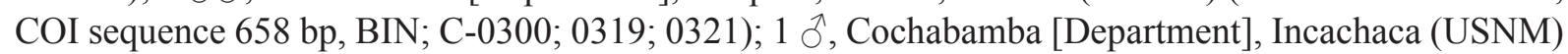
(C-0318); 1 万, [Cochabamba Department], Yungas de Arepucho, Sihuencas [Sehuencas, ca $17.504^{\circ} \mathrm{S}$,

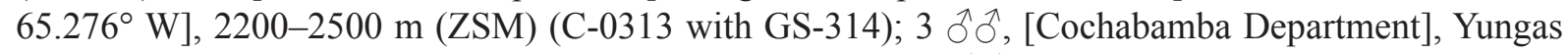
del Palmar, 2000 m (AMNH, ZSM) (C-0314; 0316; 0317); 4 ठึ ${ }^{\lambda}$, [Cochabamba Department], Yungas de Corani, $2500 \mathrm{~m}$, [ca $17.221^{\circ} \mathrm{S}, 65.817^{\circ} \mathrm{W}$ ], (ZSM) (C-0322-0325).

\section{Description}

Male and female as illustrated.

\section{Distribution}

Eastern Andes of southern Ecuador, Peru and Bolivia, 1900-3100 m.

\section{Remarks}

Two living males are illustrated in Figs 135 and 137. The conspicuous colours are only displayed when the moths are active. The habitat is shown in Fig. 136. It is remarkable that one of the apparently most common species of Callipia was undescribed until now.

\section{Callipia sihvoneni sp. nov. urn:1sid:zoobank.org:act:3FE12724-54E2-40FA-BAA5-69F6D10A1F4C}

Figs 94-95, 102, 126

BIN (holotype): BOLD:AAN4774.

\section{Diagnosis}

Callipia sihvoneni sp. nov. is a medium sized species of Callipia that was identified as C. parrhasiata in many museum collections. The costal area of the forewing is conspicuously striated / spotted and the apical dark brown area is usually not divided as in C. wojtusiaki sp. nov. and C. milleri sp. nov. COIbarcode: the minimum observed distance to the genetically most similar species (C. milleri sp. nov.) is $4.1 \%$. Callipia sihvoneni sp. nov. can most reliably be distinguished from the closely related C. wojtusiaki septentrionalis subsp. nov. and C. milleri sp. nov. by DNA-barcoding.

\section{Etymology}

The species is named in honour of Pasi Sihvonen, Veikkola, Finland.

\section{Type material}

Holotype (Figs 94, 102)

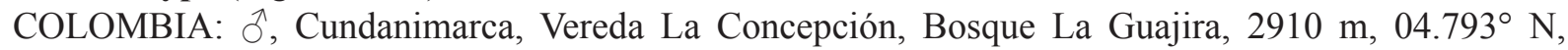
$75.783^{\circ} \mathrm{W}, 9-12$ Apr. 2014, R. Brechlin leg. (ZSM) (C-0418 with GS, COI sequence 658 bp, BIN).

\section{Paratypes}

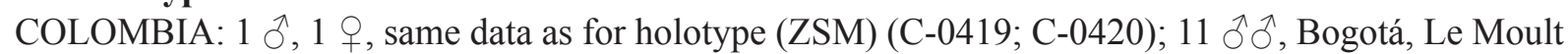
leg. (PMJ, ZSM) (C-0003 with GS-110, COI sequence: 553 bp, BIN; C-0377; C-0378 with GS-385; C-0379; 0380; 0382; C-0383 with GS-096; C-0384; 0427; 0428); 1 Oे, same data as previous, but 

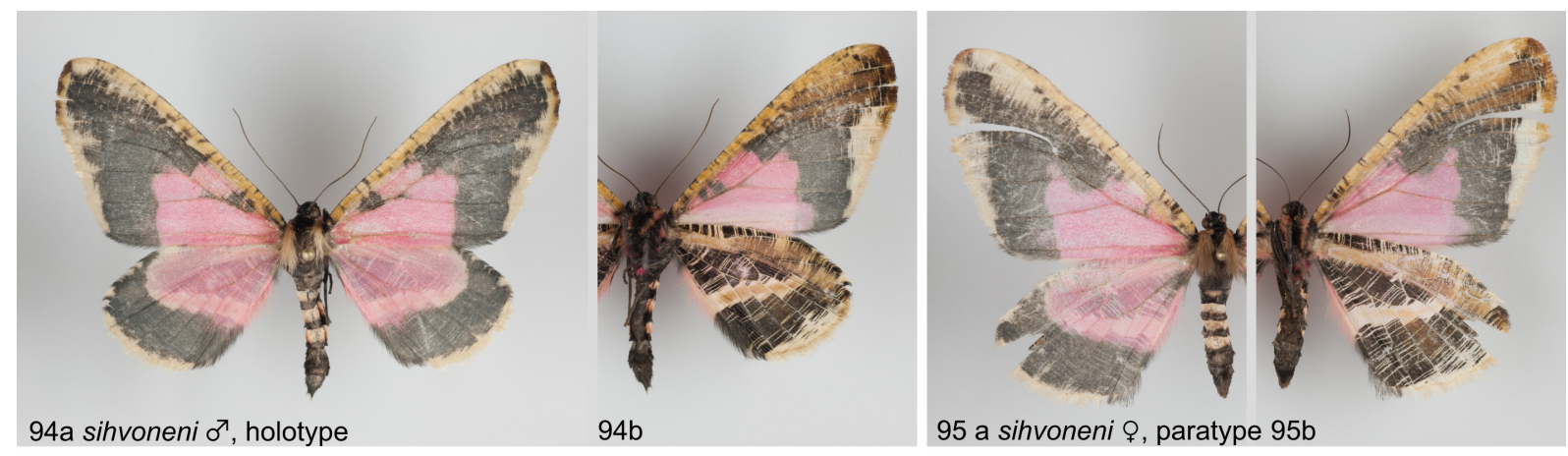

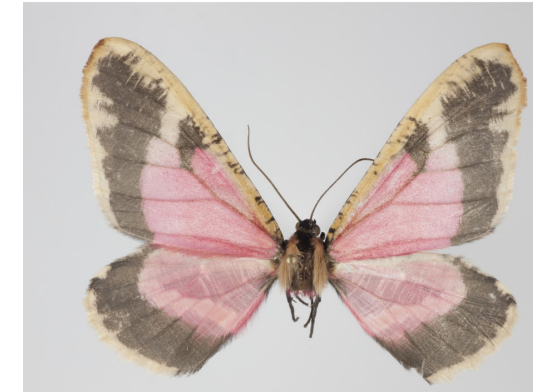

96a wojtusiaki wojtusiaki ơ', holotype

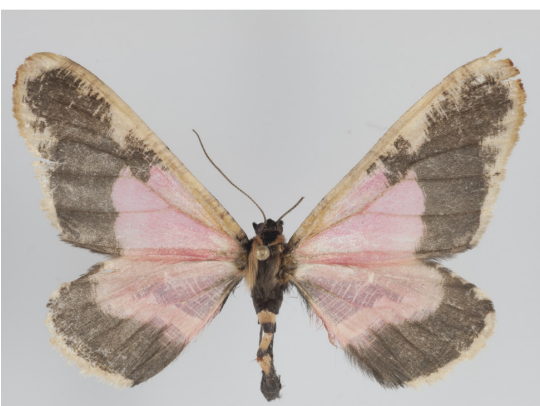

98a wojtusiaki septentrionalis $\sigma^{\nearrow}$, holotype

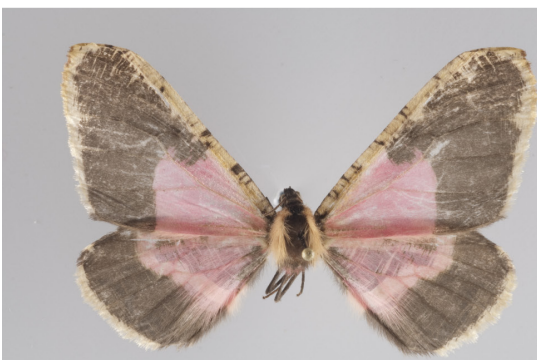

100a milleri $\sigma^{7}$, holotype

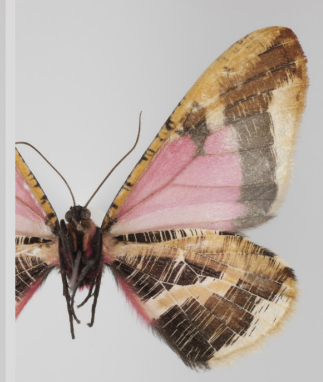

$96 \mathrm{~b}$
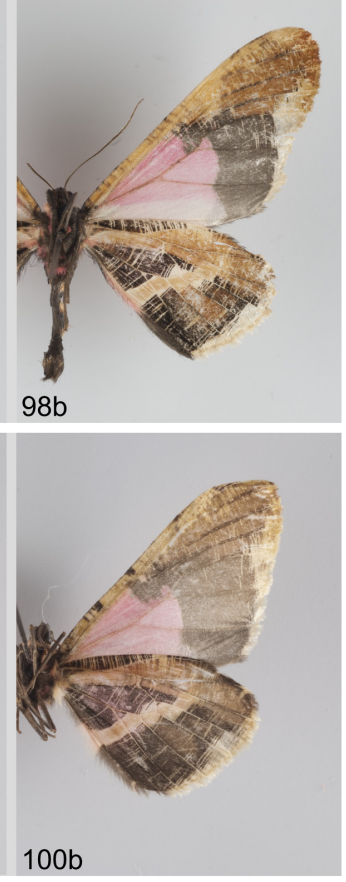

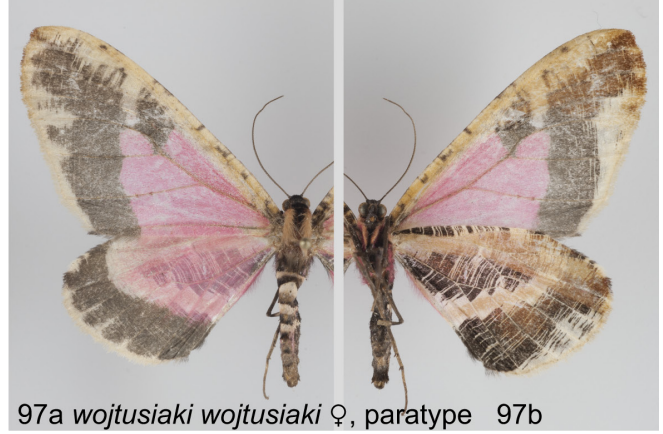

97a wojtusiaki wojtusiaki , paratype 97b

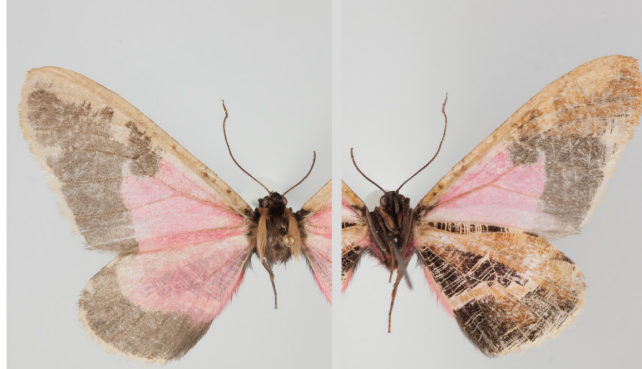

99a wojtusiaki septentrionalis $\sigma^{\nearrow}$, paratype $99 \mathrm{~b}$

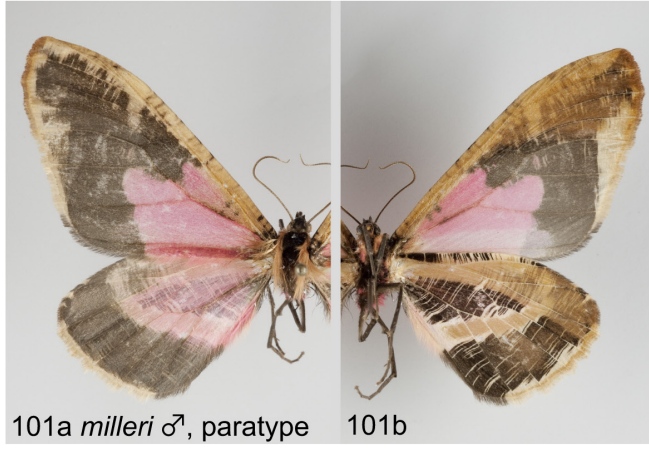

$10 \mathrm{~mm}$

Figs 94-101. Adult moths $(\mathrm{a}=$ dorsal view; $\mathrm{b}=$ ventral view). 94. Callipia sihvoneni $\mathrm{sp}$. nov., $\widehat{\partial}$, holotype (C-0418, COI data). 95. C. sihvoneni sp. nov.,, , paratype (C-0396, COI data). 96. C. wojtusiaki

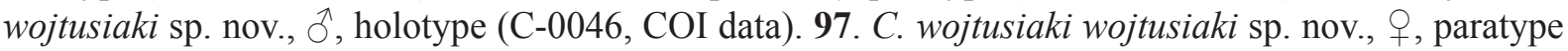
(C-0040, COI data). 98. C. wojtusiaki septentrionalis subsp. nov., $\widehat{\jmath}$, holotype (C-0012, COI data).

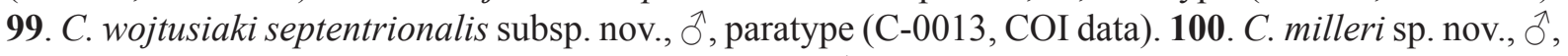
holotype (C-0370, COI data). 101. C. milleri sp. nov., ô, paratype (C-0008, COI data). 
$3200 \mathrm{~m}$ (ZSM) (C-0091); 1 $\hat{0}$, Choco près [near] Bogota (ZSM) (C-0373); $3 \hat{\jmath} \hat{\jmath}$, Pueblo Guasca,

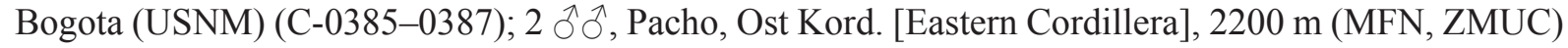
(C-0374; C-0375 with GS-303); 3 ふึત, 1 q, Boyacá, Vereda Suralá, 2730 m (ZSM) (C-0394; 0395; 0396 with GS, Figs 95, 126; C-0397).

\section{Other material examined}

COLOMBIA: 1 ô, Cauca, Jiminez, $1600 \mathrm{ft}$ [488 m] [doubtful elevation, not considered for distribution]

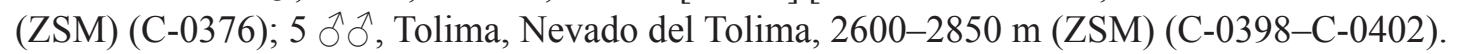
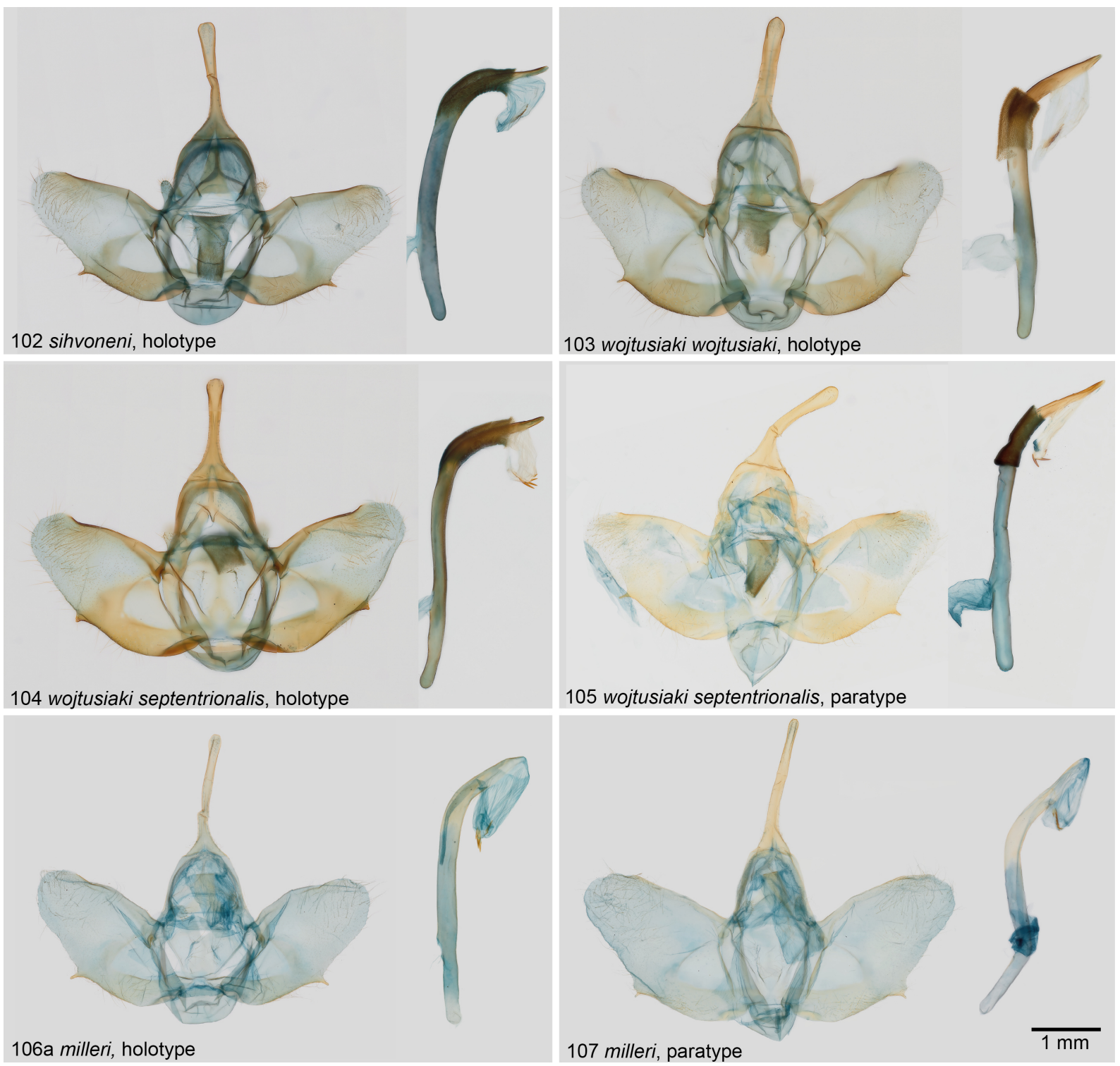

Figs 102-107. Male genitalia (left = valves; right = aedeagus). 102. Callipia sihvoneni sp. nov., $\widehat{O}$, holotype (C-0418, COI data). 103. C. wojtusiaki wojtusiaki sp. nov., ${ }^{\lambda}$, holotype (C-0046, COI data). 104. C. wojtusiaki septentrionalis subsp. nov., $\mathrm{O}^{\lambda}$, holotype (C-0012, COI data). 105. C. wojtusiaki septentrionalis subsp. nov., ô, paratype (C-0013, COI data). 106. C. milleri sp. nov., §, holotype (C0370, COI data). 107. C. milleri sp. nov., Ô, paratype (C-0008, COI data). 


\section{Description}

Male and female as illustrated.

\section{Distribution}

Western and eastern Cordillera of central and southern Colombia, 2200-3200 m. It has the northernmost distribution of all species of Callipia. It seems not to occur sympatrically with C. wojtusiaki septentrionalis subsp. nov., and might therefore only be confused with the sympatrically occurring C. milleri sp. nov.

Callipia wojtusiaki wojtusiaki sp. nov. urn:1sid:zoobank.org:act:CDF58F76-E4DD-4989-A38E-53C35604B241

Figs 96-97, 103, 127

BIN (holotype): BOLD:ABZ0453.

\section{Diagnosis}

Callipia wojtusiaki sp. nov. can reliably be separated from the subspecies C. septentrionalis subsp. nov. and from C. milleri sp. nov. by the geographical distribution and DNA barcoding only. The uncus of C. milleri sp. nov. tends to be narrower than in the more spatula-shaped uncus of $C$. wojtusiaki sp. nov. COI-barcode: the minimum observed distance to the subspecies $C$. septentrionalis subsp. nov. is $0.8 \%$, and the minimum observed distance to C. milleri sp. nov. is $1.7 \%$.

\section{Etymology}

The species is named in honour of Janusz Wojtusiak (deceased), Krakow, Poland.

\section{Type material}

Holotype (Figs 96, 103)

ECUADOR: $\sigma^{\lambda}$, Zamora-Chinchipe, Reserva Biológica San Francisco, early succession, $3.983^{\circ} \mathrm{S}$, $79.857^{\circ}$ W, 1913 m, 10 Mar. 2002, N. Hilt, K. Fiedler leg. (SMNS) (C-0046 / ID 25730 with GS, COI sequence $615 \mathrm{bp}, \mathrm{BIN})$.

\section{Paratypes}

ECUADOR: $1 \delta^{\lambda}$, with same data as for holotype, but montane rainforest, $3.973^{\circ} \mathrm{S}, 79.075^{\circ} \mathrm{W}, 1973 \mathrm{~m}$, 11 Mar. 2002 (PMJ) (C-0047 / ID 25729 with GS-113, COI sequence 589 bp, BIN); 1 ô, same data as previous, but disturbed area, $1800 \mathrm{~m}, 3.972^{\circ} \mathrm{S}, 79.079^{\circ} \mathrm{W}, 1810 \mathrm{~m}, 4$ Feb. 2013, L. Möckel leg. (RCGB) (ID 48462); 2 $\widehat{\jmath}$, Loja surroundings, 1890 [sampling year] (USNM) (C-0019, COI sequence $658 \mathrm{bp}$ (6 bp gap); C-0357), these two specimens are also syntypes of intermedia stat. rev., but are not conspecific with the lectotype of intermedia stat. rev. from Peru (see C. intermedia stat. rev.); 1 , Morona-Santiago, Limon-Gualaceo Road, east, 3.024 ${ }^{\circ}$ S, 78.585 $\mathrm{W}, 2450 \mathrm{~m}, 20$ Aug. 2003, R. Garlacz

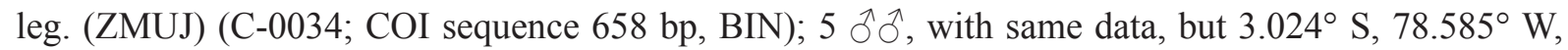
2200 m, 30 Aug. 2003, J. Wojtusiak leg. (ZMUJ) (C-0035-0037; 0041; 0043; COI sequences 616-658 bp, all with BIN); 1 + , with same data (C-0040, figs. 97, 127); 2 ôे, Morona-Santiago, Rio Culebrillas, $34 \mathrm{~km} \mathrm{SE}$ of Gualaceo, 3.133 ${ }^{\circ} \mathrm{S}, 78.55^{\circ} \mathrm{W}, 2200 \mathrm{~m}, 22-23$ Oct. 1987, Jan Hillman leg. (CMNH) (C0014, COI sequence 658 bp, BIN; C-0354).

PERU: $1 \mathrm{O}^{\top}$, Amazonas, Route Moyobamba à Jaén, km 77, [5.683 S, 77.717 W], 2000 m, 23 Sep. 2003, A. Lévêque leg. (MNHN) (C-0017 with GS-318, COI sequence 658 bp, BIN). 


\section{Distribution}

Eastern Andes of southern Ecuador and northern Peru: 1800-2600 m. It seems that $C$. wojtusiaki sp. nov. does not occur sympatrically with the subspecies septentrionalis subsp. nov., or with milleri sp. nov. or sihvoneni sp. nov.

Callipia wojtusiaki septentrionalis subsp. nov. urn:lsid:zoobank.org:act:45B9DA19-B4BF-41F8-AED3-D17A4B45C356

Figs 98-99, 104-105

BIN (holotype): BOLD:ACF3549.

\section{Diagnosis}

Callipia wojtusiaki septentrionalis subsp. nov. can reliably be separated from the nominate form by the geographical distribution and DNA barcoding only. The uncus of $C$. milleri sp. nov. tends to be narrower than in the more spatula-shaped uncus of $C$. wojtusiaki sp. nov. COI-barcode: the minimum observed distance to the nominate species is $0.8 \%$, and the minimum observed distance to C. milleri sp. nov. is $1.0 \%$.

\section{Etymology}

This subspecies of C. wojtusiaki sp. nov. is distributed in the northern part of the species' range and thus named septentrionalis from Latin, meaning 'northern'.

\section{Type material}

Holotype (Figs 98, 104)

ECUADOR: ${ }^{\lambda}$, Napo, South slopes of Cerro Sumaco, wet cloud $/$ moss forest, $0.559^{\circ} \mathrm{S}, 77.626^{\circ} \mathrm{W}$, 2950 m, 18 Nov. 1995, Jan Hillman leg. (CMNH) (C-0012 with GS, COI sequence 658 bp, BIN).

\section{Paratypes}

ECUADOR: $1 \mathrm{\partial}^{\lambda}$, collection data as for holotype, but cloud forest, landslide, $0.600^{\circ} \mathrm{S}, 77.483^{\circ} \mathrm{W}$,

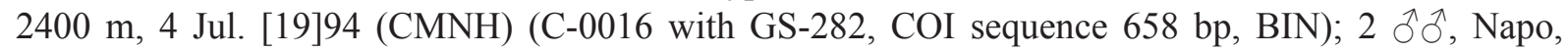
SE slope Reventador, subparamo at treeline, $0.085^{\circ} \mathrm{S}, 77.655^{\circ} \mathrm{W}, 3200 \mathrm{~m}, 6$ Jul. 1994, Jan Hillman leg. (CMNH) (C-0013 with GS-414, COI sequence 658 bp, BIN, Figs 99, 105; C-0365); 1 ठ, Napo, El Salado, 78 km (road) E of Papallacta, 1310 m, 17 Jan. 1986, McKamey and Osborne leg. (AMNH) (C0362, COI sequence 658 bp, BIN); 1 ô, Napo, R[ou]te Cosanga-Tena, km 10, 2230 m, 15 Nov. 1983, C. Lemaire and N. Venedictoff leg. (ZSM) (C-0363 with GS-306, COI sequence 307 bp); 1 ふै, Sucumbios, El Calvario, $0.060^{\circ}$ N, $77.483^{\circ}$ W, 2800 m, 7 Aug. 1996, G. Onore, E. Tapia and F. Salazar leg. (CMNH) (C-0015, COI sequence 550 bp, BIN); 1 đ, [Napo?], Route Baeza-Lumbaqui, at Puente Azuela, $1530 \mathrm{~m}$, 6-7 Feb. 1975, C. Herbulot leg. (ZSM) (C-0364 with GS-106, COI sequence 307 bp).

\section{Other material examined}

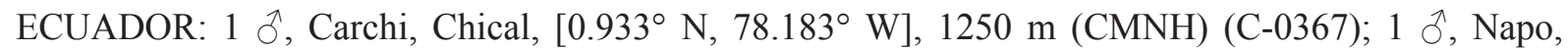
Rio Pucuno, $42 \mathrm{~km}$ SE of Baeza on road to Loreto, $0.708^{\circ} \mathrm{S}, 77.598^{\circ} \mathrm{W}, 1045 \mathrm{~m}$ (AMNH) (C-0164); $2 \widehat{\partial} \partial^{\lambda}$, Napo, Cordillera Huacamayos, Rio Cedroyacu, $0.887^{\circ} \mathrm{S}, 78.077^{\circ} \mathrm{W}, 2100 \mathrm{~m}$ (CMNH, RCGB) (C-0009; 0368); 1 $\lambda$, Napo, Cordillera Huacamayos, Estero Chico, 2650 m (CMNH) (C-0369); 2 $\widehat{\jmath}$, [Napo], Tena, $450 \mathrm{~m}$ [doubtful locality / elevation] (ZSM) (C-0358; 0359).

\section{Description}

Male as illustrated. Female unknown. 


\section{Distribution}

Paratypes are exclusively from north eastern Ecuador, but further study of specimens from north western Ecuador is required.

Callipia milleri sp. nov.

urn:1sid:zoobank.org:act:CA8B2C53-C4C4-493E-988C-ABCAC06E649B

Figs 100-101, 106-107

BIN (holotype): BOLD:AAI3924.

\section{Diagnosis}

Closest relative of $C$. wojtusiaki sp. nov. and C. wojtusiaki septentrionalis subsp. nov. The geographical range overlaps with the latter. The male uncus is narrower than in C. wojtusiaki sp. nov. The wing patterns do not offer reliable diagnostic characters. COI-barcode: the minimum observed distance to C. milleri sp. nov. is $1.0 \%$.

\section{Etymology}

The species is named in honour of James S. Miller (AMNH), USA.

\section{Type material}

Holotype (Figs 100, 106)

ECUADOR: ${ }^{\top}$, Carchi, $35 \mathrm{~km}$ W of Tufino, west slope, 3120 m, 30 Nov. 1987, C. Young and R. Davidson leg. (CMNH) (C-0370 with GS-311, COI sequence 658 bp, BIN).

\section{Paratypes}

COLOMBIA: 1 đ̃, [Valle del Cauca], Calí, 1000 m, 19 Aug. 1973 (RCGB) (C-0004 with GS-279, COI sequence $658 \mathrm{bp}, \mathrm{BIN}) ; 1$ ô, [Valle del Cauca], Calima Dam, [03.881 ${ }^{\circ} \mathrm{N}, 76.558^{\circ} \mathrm{W}$ ], $3000 \mathrm{ft}$ [914 m], 15 Jan. 1985, J. Bolling Sullivan leg. (Bolling collection) (C-0001, COI sequence 566 bp

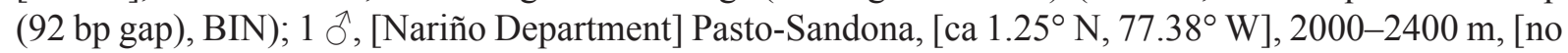
date], Werner Hopp leg. (ZSM) (C-0002 with GS-313, COI sequence 658 bp, BIN)

ECUADOR: $2 \widehat{\jmath}$, Cotopaxi, W of Pilalo, 1800 m, 9-10 Oct. 1977, L.E. Peña leg. (AMNH, PMJ) (C0361 with GS-310, COI sequence 307 bp; C-0360); 2 ôे, Pichincha, Las Palmeras, $59 \mathrm{~km}$ W Quito, $8 \mathrm{~km} \mathrm{~W}$ of Chiriboga, $6400 \mathrm{ft}$ [1951 m], 15 Oct. 1988, J.S. Miller leg. (AMNH) (C-0005 with GS320, COI sequence 589 bp, BIN; C-0371, COI sequence 658 bp, BIN); 1 Oे, Pichincha, $26 \mathrm{~km} \mathrm{WNW}$ Machachi, humid primary forest, 1900 m, 12 Nov. 1987, J. Rawlins, C. Young and R. Davidson leg. $(\mathrm{CMNH})(\mathrm{C}-0006, \mathrm{COI}$ sequence 658 bp, BIN); 1 ô, Napo, Hazienda Bosque on road Quito-Baeza, disturbed montane forest, 2600 m, 11 Nov. 1995, Jan Hillman leg. (NHM) (C-0007, COI sequence 658 bp, BIN); 1 ô, Napo, 12.8 km SE of Papallacta on road Papallacta-Baeza, 2440 m, 30 May 1993, J.S. Miller leg. (AMNH) (C-0008 with GS-307, COI sequence 658 bp, BIN, Figs 101, 107).

\section{Other material examined}

COLOMBIA: $5 \hat{\jmath} \hat{\jmath}$, [Valle del Cauca], Calima Dam, [03.881 ${ }^{\circ} \mathrm{N}, 76.558^{\circ} \mathrm{W}$ ], $3000 \mathrm{ft}[914 \mathrm{~m}$ ], (Sullivan collection) (C-0163; 0165-0168); 1 §ै, [Cauca], Jiminez, $1600 \mathrm{ft}$ [488 m] [doubtful elevation, not considered in observed distribution], (USNM) (C-0372); 1 male Cali (ZSM).

ECUADOR: $1 \hat{\jmath}$, Carchi, La Alegria on road between La Bonita and Santa Barbara, $2700 \mathrm{~m}$, 14 Sep. 1977 (AMNH) (C-0366); 1 ô, Pichincha, Quito - Nanegalito, $37 \mathrm{~km}, 0.018^{\circ} \mathrm{N}, 78.615^{\circ} \mathrm{W}$,

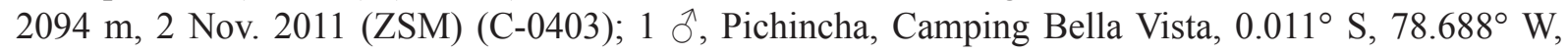


2230 m, 27 Oct. 2011 (ZSM) (C-0404); 2 đ̂̀, Pichincha, Tandayapa, 3,5 km S, (Bellavista Lodge), $00^{\circ} 03.70^{\prime} \mathrm{N}, 78^{\circ} 40.93^{\prime} \mathrm{W}$ [coordinates incorrect], $2310 \mathrm{~m}, 1-20$ Nov. 2012 (ZSM) (C-0429, 0430).

\section{Description}

Male as illustrated. Female unknown.

\section{Distribution}

Western Cordillera of southern Colombia, western and eastern Cordillera of northern Ecuador, 900$2500 \mathrm{~m}$.

\section{Callipia fulvida Warren, 1907}

Figs 108-109, 116-117, 128

Assigned BIN: BOLD:AAI6978.

\section{Diagnosis}

Among the four species with a yellow-red ground colour (in comparison with the deep rosy species around C. parrhasiata), C. fulvida tends to have the most yellowish colour, but this is not a fully reliable diagnostic feature. The extent of yellow (vs dark brown) is most extended in C. fulvida among the four species, and the yellow blotch always reaches the costa at about two thirds from the base, producing an isolated brown spot. Although this is also seen in some individuals of the other species, the combination of these characters in combination with the geographical distribution will usually allow to identify C. fulvida without DNA barcoding or dissection. COI-barcode: the minimum observed distance to the genetically most similar (but not similar looking) species (C. rosetta) is $4.4 \%$.

\section{Type material}

Originally two syntypes (males) from Peru, [Puno], Carabaya, Agualani, $9000 \mathrm{ft}$ [2743 m], Mar. 1905, wet season, [G.R.] Ockenden leg. (NHM). One male was selected as lectotype (Figs 108, 116).

\section{Other material examined}

PERU: 12 $\widehat{\partial}$, same collection data as for lectotype (AMNH, RCGB, SMF, ZSM) (C-0078; 0171; 0173; 0176-0184); 4 $\widehat{\jmath}$, Puno, $5 \mathrm{~km}$ E of Limbani, $3000 \mathrm{~m}$ (ZMUC) (C-0076 with GS-293, COI sequence 658 bp, BIN; C-0077 with GS-303, COI sequence 658 bp, BIN; C-0174 with GS-450, COI sequence 307 bp, Figs 109, 117; C-0175).

BOLIVIA: 1 , [La Paz Department], Cuesta von Cillutincara [Cerro de Sillutincara, ca $16.29^{\circ} \mathrm{S}$, $67.90^{\circ} \mathrm{W}$ ], 3000-3500 m (ZSM) (C-0172 with GS, Fig. 128).

\section{Description}

Male and female as illustrated.

\section{Distribution}

Eastern Andes of south eastern Peru and Bolivia, 2700-3000 m.

Callipia flagrans Warren, 1904

Figs 110-111, 118-119

Assigned BIN: BOLD:AAI6982. 

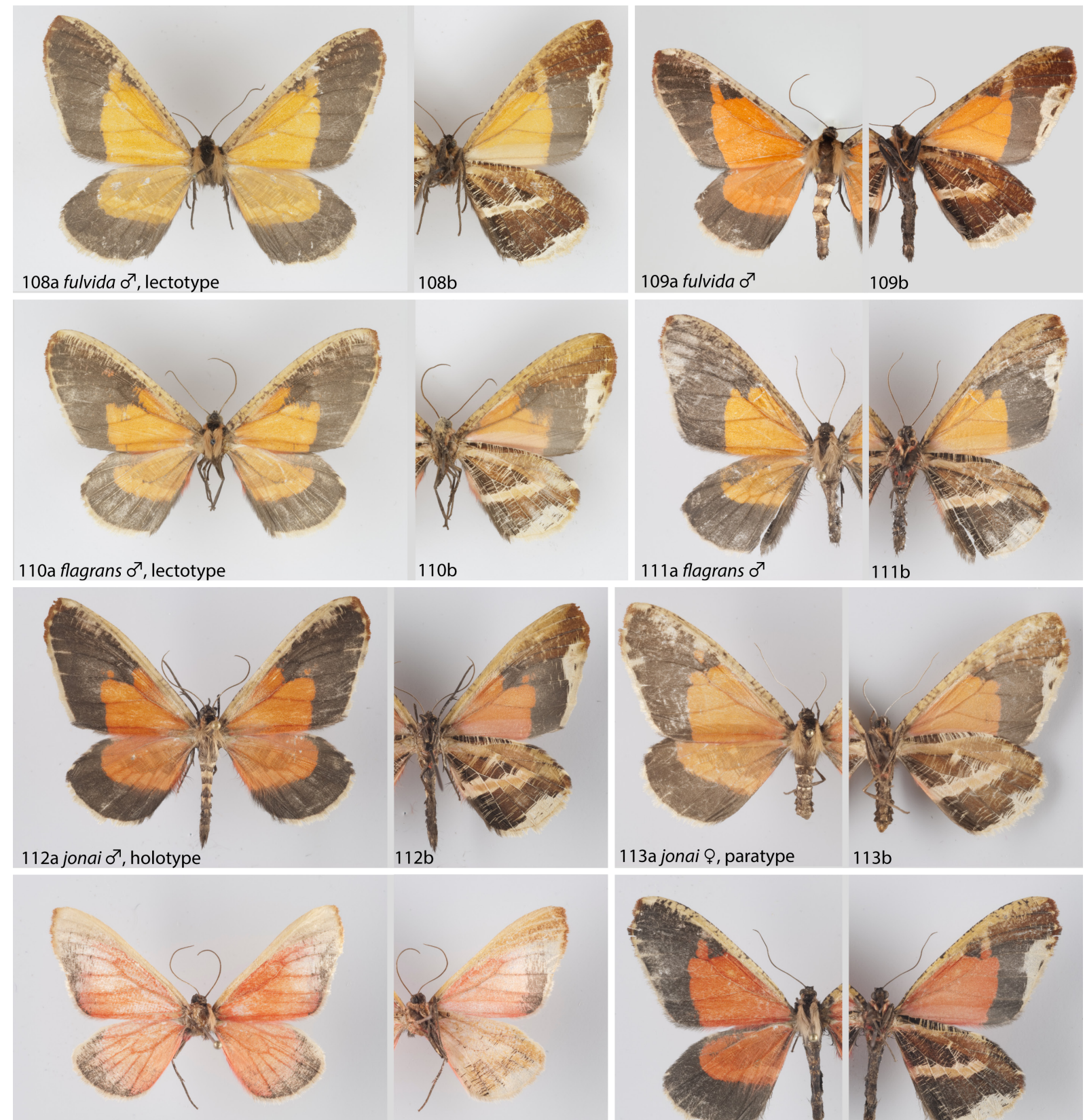

114a levequei $\sigma^{7}$, holotype

$114 b$

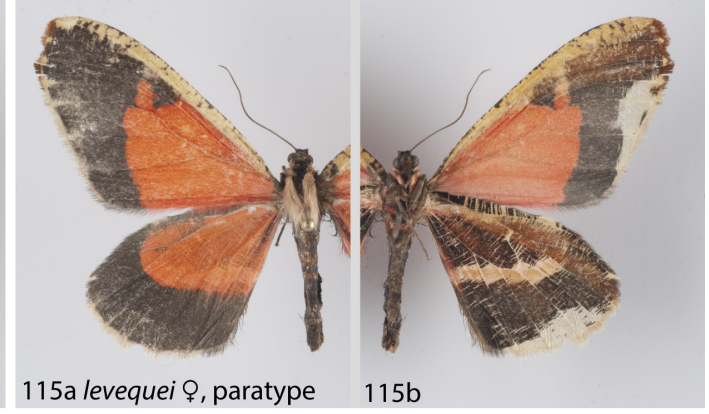

$\overline{10 \mathrm{~mm}}$

Figs 108-115. Adult moths $(\mathrm{a}=$ dorsal view; $\mathrm{b}=$ ventral view). 108. Callipia fulvida Warren, 1907, $\hat{\partial}$, lectotype (NHM). 109. C. fulvida Warren, 1907, ô (C-0174, COI data). 110. C. flagrans Warren, 1904, $\widehat{\jmath}$, lectotype (NHM). 111. C. flagrans Warren, 1904, ô (C-0022, COI data). 112. C. jonai sp. nov., ô, holotype (C-0020, COI data). 113. C. jonai sp. nov.,, , paratype (C-0217). 114. C. levequei sp. nov., ${ }^{\top}$, holotype (C-0073, COI data). 115. C. levequei,, , paratype (C-0071, COI data). 

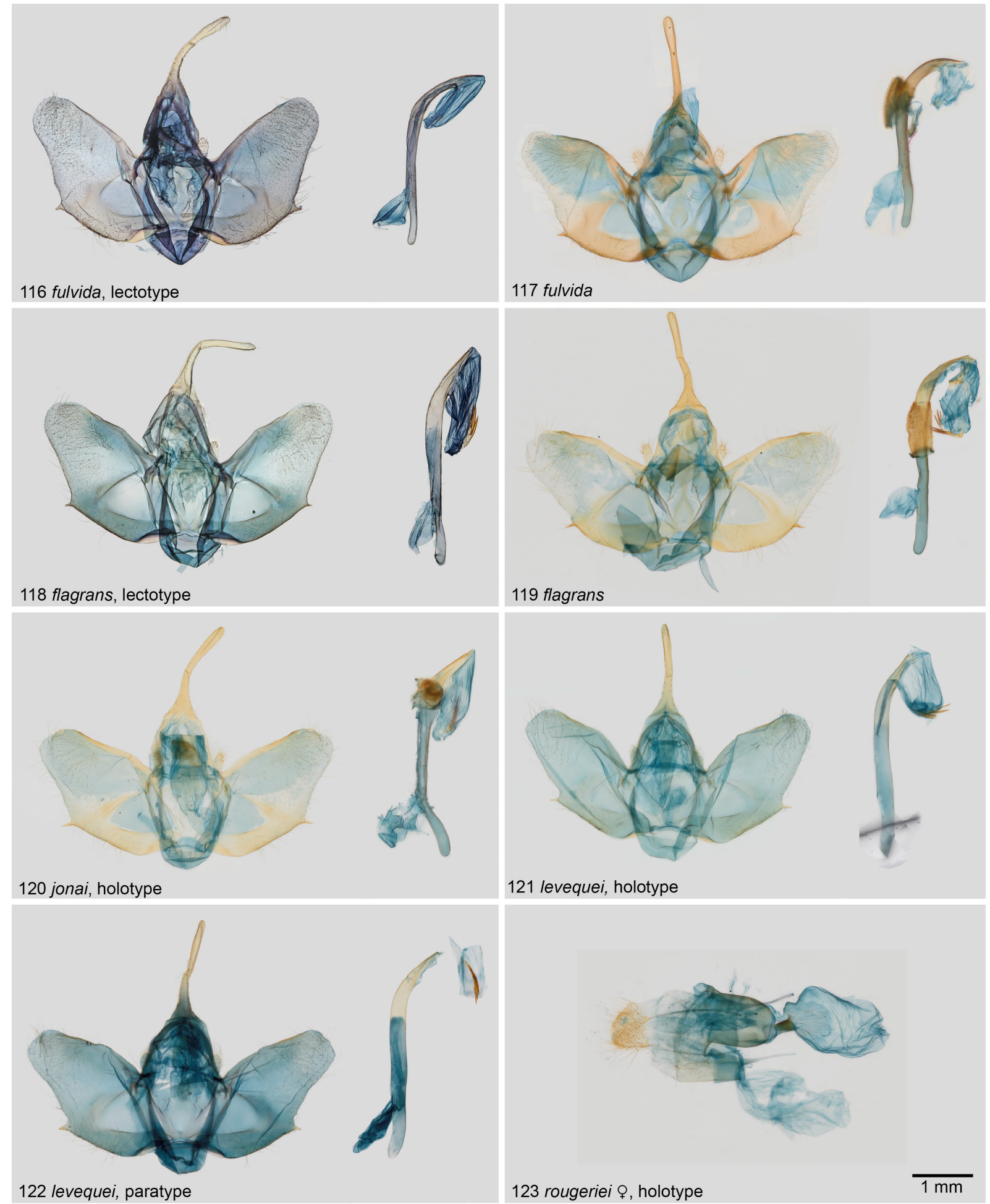

Figs 116-123. Male genitalia (left $=$ valves; right $=$ aedeagus $)$ and female genitalia. 116. Callipia fulvida Warren, 1907, §̂, lectotype (NHM). 117. C. fulvida Warren, 1907, ô (C-0174, COI data). 118. C. flagrans Warren, 1904, $\widehat{\jmath}$, lectotype (NHM). 119. C. flagrans Warren, 1904, $\widehat{\jmath}$ (C-0022, COI data). 120. C. jonai sp. nov., ô, holotype (C-0020, COI data). 121. C. levequei sp. nov., ô, holotype (C-0073, COI data). 122. C. levequei sp. nov., ${ }^{\lambda}$, paratype (C-0072, COI data). 123. C. rougeriei sp. nov.,, , holotype (C0069, COI data). 


\section{Diagnosis}

The extent of dark brown colour is larger than in C. fulvida, see diagnosis in this species. Callipia levequei sp. nov. has a considerably more intense ground colour than flagrans. Callipia flagrans and C. jonai sp. nov. are very similar and can most reliably be distinguished by DNA-barcoding. The ground colour in $C$. flagrans is more yellow than in $C$. jonai sp. nov., and the species appear to be geographically separated (C. flagrans in Peru, C. jonai sp. nov. in Bolivia). COI-barcode: the minimum observed distance to the genetically most similar (but not similar looking) species (C. augustae sp. nov.) is $2.6 \%$.

\section{Type material}

Originally 3 syntypes (males) from Peru, [Puno], River Inambari, 1000 m, July 1900, rainy season, Simons leg. (NHM). One of these males is designated as lectotype (Figs 110, 118).

\section{Other material examined}

PERU: 2 $\widehat{\partial}$, (MFN, MNHN) (C-0267, 0272); 1 ð, [San Martín], Jepelacio (USNM) (C-0271); 3 $\widehat{\partial}$,

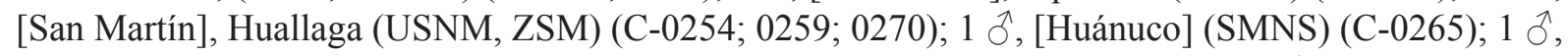
[Pasco], Yanachaga [Parque nacional Yanachaga-Chemillén] (MfN) (C-0263); 1 ô, [Pasco] Quiroz (AMNH) (C-0273 with GS-277); 1 $\delta$, [Pasco], Huancabamba, 6-10000 ft [1829-3048 m] (MNHN) (C-0268); $4 \hat{\jmath} \widehat{\partial}$, [Pasco], Huancabamba, Cerro de Pasco (NHM, SMF) (C-0253 with GS-156; C-0260 with GS-111; C-0261; 0264); 1 ô, [Pasco], Huancabamba, 1000 m (MFN) (C-0252); 1 ô, [Pasco],

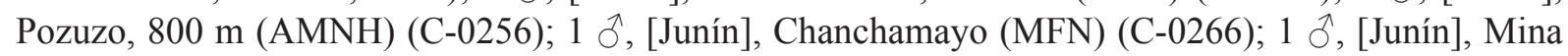

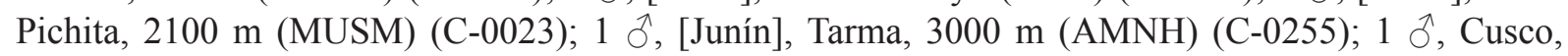
Vilcanota, $3000 \mathrm{~m}$ (SMF) (C-0262); 1 oे, [Cusco], Machupicchu (AMNH) (C-0024 with GS-278, COI sequence 295 bp (148 bp gap)); 1 ऽ$^{\top}$, Cusco, Cosñipata, $2360 \mathrm{~m}, 13.157^{\circ} \mathrm{S}, 71.596^{\circ} \mathrm{W}(\mathrm{C}-0475$, Pe-Geo-0341, COI sequence $658 \mathrm{bp}, \mathrm{BIN}) ; 1 \hat{\jmath}$, [Cusco], Valle de Marcapata (USMSM) (C-0269); $1 \hat{\jmath}$, [Puno, Rio] Chirimayo (USNM) (C-0258); $1 \hat{\jmath}$, Madre de Dios, Tambopata Reserve, Explorer's Inn, $12^{\circ} 51^{\prime} \mathrm{S}, 69^{\circ} 18^{\prime} \mathrm{W}, 200 \mathrm{~m}$ [doubtful record] (AMNH) (C-0022 with GS-415, COI sequence 658 bp, BIN, Figs 111, 119).

\section{Distribution}

Eastern Andes of Peru with records from the north to the south east, 800-3100 m.

Callipia jonai sp. nov.

urn:1sid:zoobank.org:act:E160FE45-8B84-4464-852B-05C52EFF4312

Figs $112-113,120,129$

BIN (holotype): BOLD:AAI6981.

\section{Diagnosis}

Specimens of $C$. jonai sp. nov. were frequently assigned to flagrans in museum collections, but when seen in larger series, $C$. jonai sp. nov. has a deeper orange-red than flagrans which is more yellowish. See also diagnosis in $C$. flagrans. COI-barcode: the minimum observed distance to the genetically most similar (but not similar looking) species (C. intermedia stat. rev.) is $2.7 \%$.

\section{Etymology}

The species is named in honour of my son Jona Brehm, Jena, Germany. 


\section{Type material}

Holotype (Figs 112, 120)

BOLIVIA: Ō, Cochabamba [Department], Chapare, 2000 m, Feb. 1995, G. Lachaume leg. (ZSM) (C0020 with GS-410, COI sequence 620 bp, BIN).

\section{Paratypes}

BOLIVIA: 1 đ, Cochabamba [Department], Yungas de Incachaca, 2100 m, 10 Feb. [19]59, R. Zischka leg. (ZSM) (C-0221 with GS-166, COI sequence 356 bp); 2 $ぇ$, Cochabamba [Department], Incachaca

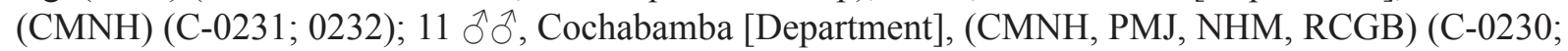
0234; 0235; 0237-0242; C-0247 with GS-276; C-0248 with GS-290); 1 ㅇ, same data as previous (C0217 with GS, Figs 113, 129).

\section{Other material examined}

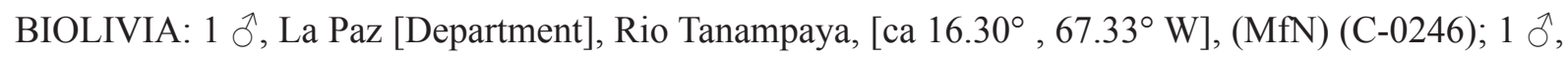
[Cochabamba Department], Chapare (AMNH) (C-0228); 1 ô,Cochabamba [Department] (CMNH) (C-

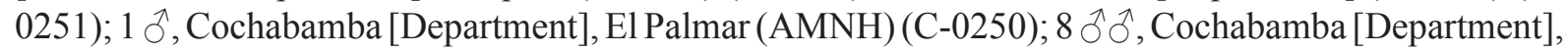
Chapare (ZSM) (C-0219; 0220; 0223; 0226; 0229; 0233, 0243; 0244); 1 , Tanamp.[aya] [ca $16.30^{\circ} \mathrm{S}$, $67.33^{\circ} \mathrm{W}$ ], (MfN) (C-0222); $1 \hat{\jmath}$, Yungas de Corani, $2500 \mathrm{~m}$ (ZSM) (C-0224); $6 \hat{\jmath} \hat{\jmath}$, Yungas de Palmar, 1000 and $2000 \mathrm{~m}$ (AMNH, ZSM) (C-0206; 0225; 0227; 0236; 0245; 0249).

[ARGENTINA]: 1 §, Buenos Aires [location doubtful] (AMNH) (C-0218).

\section{Distribution}

Eastern Andes of western and central Bolivia, 1000-2000 m.

Callipia levequei sp. nov. urn:1sid:zoobank.org:act:A290D0E4-627E-450A-8734-C4C8A20911D8

Figs 114-115, 121-122, 130

BIN (holotype): BOLD:AAI3931.

\section{Diagnosis}

Among all Callipia of the parrhasiata group, C. levequei sp. nov. has the deepest red colour. The holotype probably represents a chromatic abberation (Fig. 114), other males have the same appearance as the female illustrated in Fig. 115. Callipia levequei sp. nov. also tends to be smaller than $C$. jonai sp. nov. and $C$. flagrans, possibly the closest related species. The male genitalia do not offer clear diagnostic characters, when compared to $C$. jonai sp. nov. and flagrans. COI-barcode: the minimum observed distance to the genetically most similar (but not similar looking) species (C. intermedia stat. rev.) is $3.4 \%$.

\section{Etymology}

The species is named in honour of Antoine Lévêque, Paris, France.

\section{Type material}

Holotype (Figs 114, 121)

ARGENTINA: đ̃ Jujuy, Parc National Calilegua, Abra de Cañas, $1680 \mathrm{~m}$, [ca $23.47^{\circ} \mathrm{S}, 64.55^{\circ} \mathrm{W}$ ], [no date], P. Schmitt leg. (MNHN) (C-0073) with GS-298, COI sequence 658 bp, BIN). 


\section{Paratypes}

ARGENTINA: $1 \hat{\partial}$, same collection data as for holotype (C-0072 with GS-299, COI sequence $658 \mathrm{bp}$, BIN, Fig. 122) (MNHN); 1 \%, same collection data as for holotype (C-0071 with GS-418, COI sequence

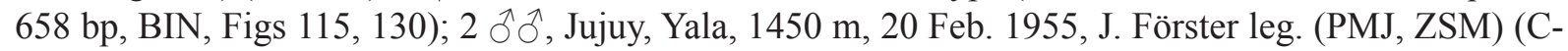
0185; 0187).
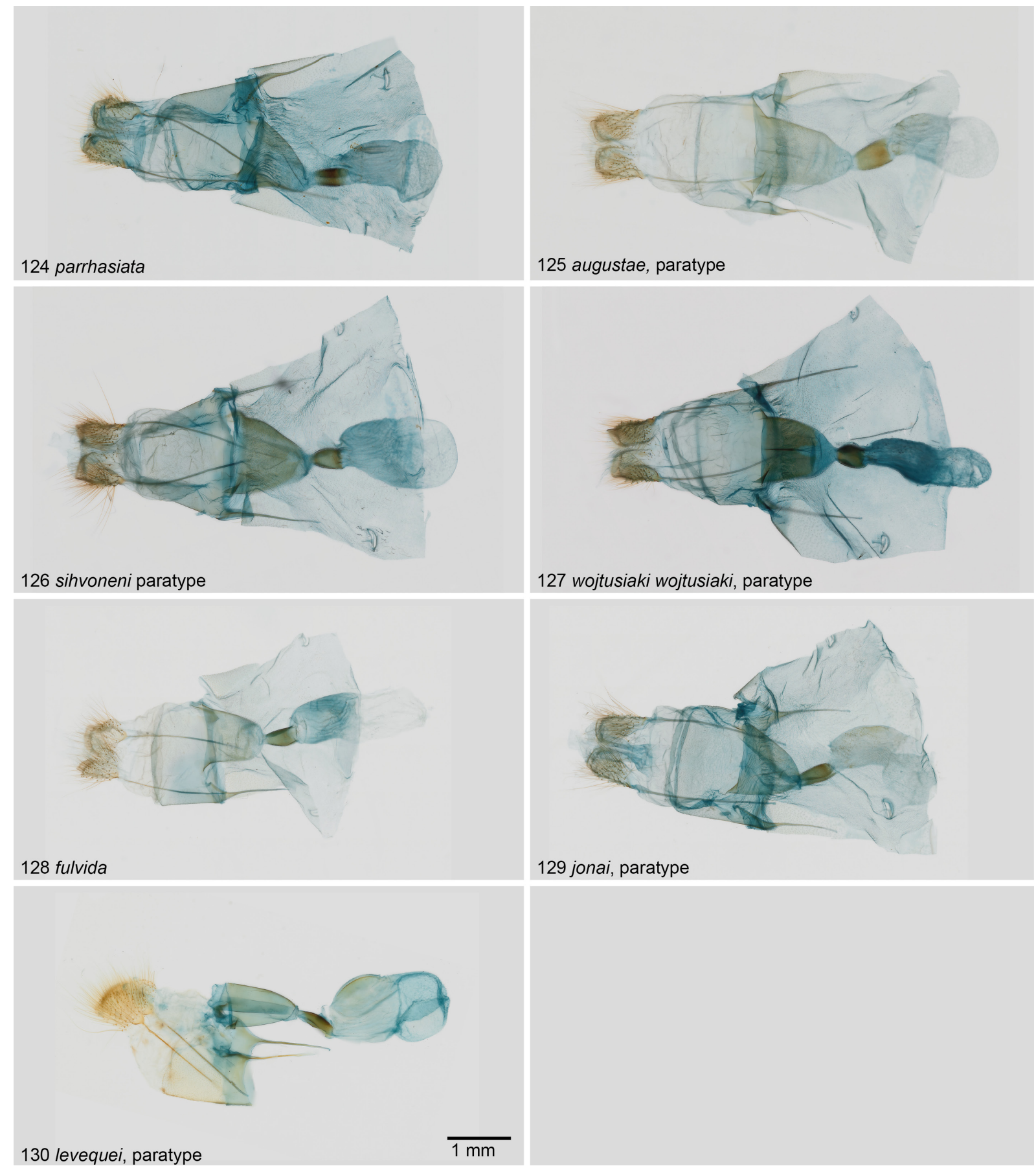

129 jonai, paratype

Figs 124-130. Female genitalia. 124. Callipia parrhasiata Guenée, 1858, $q$ (C-0431). 125. C. augustae sp. nov., + , paratype (C-0432). 126. C. sihvoneni sp. nov., + , paratype (C-0396, COI data). 127. C. wojtusiaki wojtusiaki sp. nov., + , paratype (C-0040, COI data). 128. C. fulvida Warren, 1907,, , (C-0172). 129. C. jonai sp. nov.,, , paratype (C-0217). 130. C. levequei sp. nov., + , paratype (C-0071). 

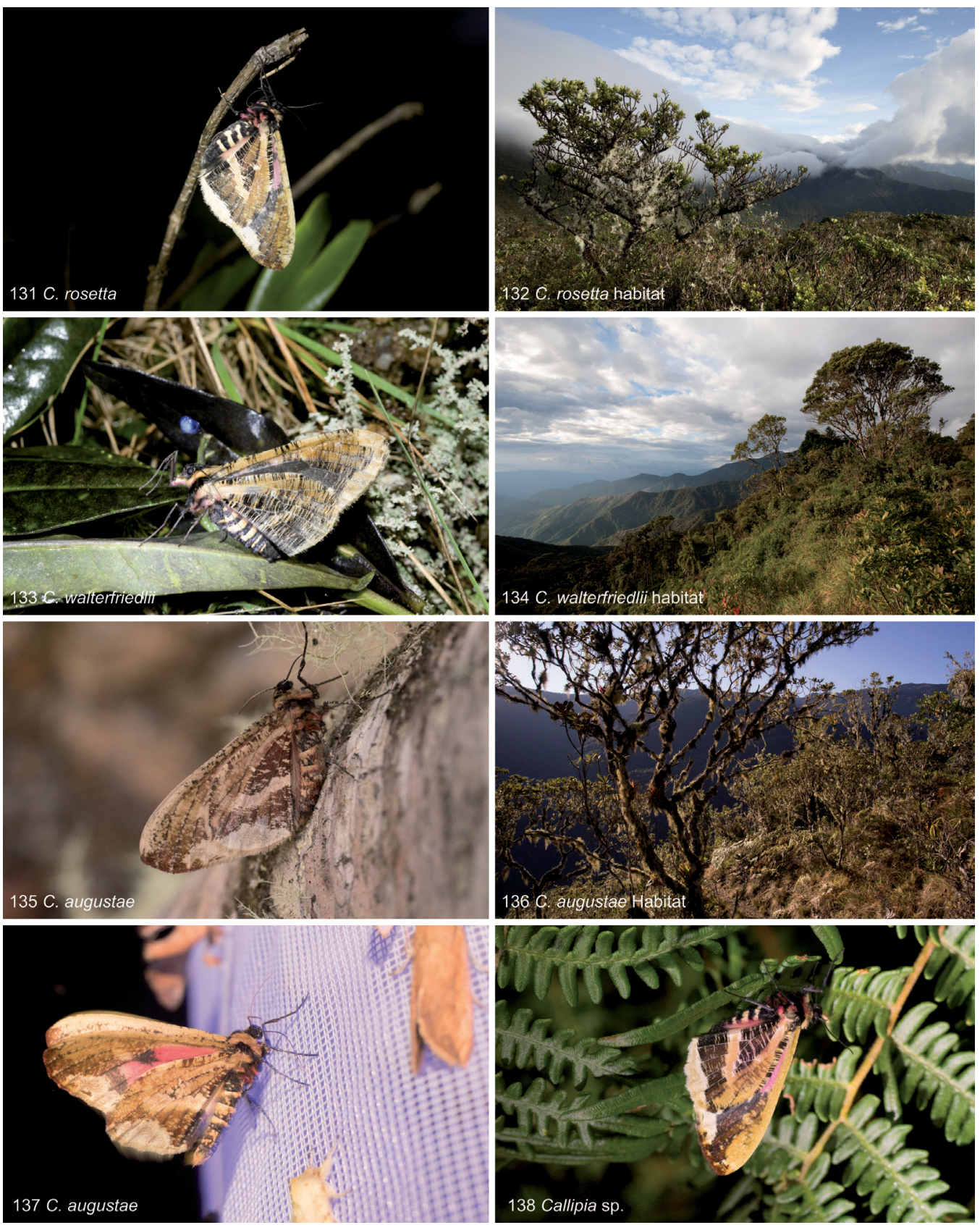

Figs 131-138. Living specimens and habitats. 131. Callipia rosetta Thierry-Mieg, 1904, $\widehat{\partial}$, Ecuador, Loja province, Podocarpus National Park, Cajanuma, 2897 m, 26 Mar. 2011. The specimen was attracted to light and benumbed. 132. Elfin forests are a habitat of C. rosetta Thierry-Mieg, 1904 and C. walterfriedlii sp. nov., Ecuador, Loja province, Podocarpus National Park, Cajanuma, $3000 \mathrm{~m}$, 30 Jan. 2013. 133. C. walterfriedlii sp. nov., + , Ecuador, Loja province, Podocarpus National Park, Cerro Toledo, $2938 \mathrm{~m}, 27$. Feb. 2013. The specimen was attracted to light and benumbed. 134. Habitat (elfin forest) of C. walterfriedlii sp. nov. at Cerro Toledo. 135. C. augustae sp. nov., $\widehat{\jmath}$, Peru, Cusco province, Wayqecha station, $2900 \mathrm{~m}, 26$ Aug. 2016. The specimen was collected at night, trapped, photographed and released the next morning. 136. Habitat of C. augustae sp. nov. and Callipia sp. near Wayqecha station. 137. C. augustae sp. nov., đ, Peru, Cusco province, road Wayqecha-Pillcopata, $2284 \mathrm{~m}, 23$ Aug. 2016. The specimen was attracted to UV light and tried to take up fluid (see proboscis). 138. Callipia sp. at Wayqecha station, 4 Sep. 2016. This specimen was attracted to UV light, but escaped into the vegetation when disturbed. 


\section{Other material examined}

BOLIVIA: 1 ô, Cochabamba [Department], Chapare, Paracti (AMNH) (C-0021, COI sequence 554

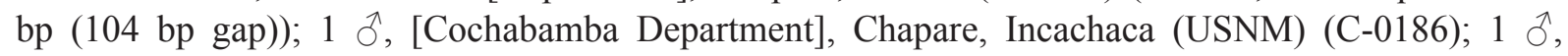
Cochabamba [Department] (CMNH) (C-0188).

\section{Distribution}

Eastern Andes of northern Argentina and Bolivia, $1700 \mathrm{~m}$.

\section{Discussion}

Remarkably, the number of species increased substantially even in a rather conspicuous moth taxon from 10 to now 26 valid Callipia species. This shows that species richness of tropical moths can be strongly underestimated even in taxa that were regularly sampled and usually not overlooked. The situation in less conspicuous taxa is much worse: higher proportions of species still remain undescribed, and many species of small taxa (such as Eupithecia Curtis, 1825) still need to be sampled, because they are not represented in any museum collection. For example, Brehm et al. (2011) estimated the percentage of undescribed species in the Neotropical Larentiinae genus Eois Hübner, 1818 at 85\%.

This revision is far from being perfect, but in my view the results represent a significant progress in the taxonomy of Callipia and a small step in the systematics of Geometridae. When I started working for this paper more than twelve years ago, I focused on morphological characters - and got stuck in a dead end. For example, specimens around C. parrhasiata appeared highly variable, but did they all belong to one single, widespread species? Unfortunately, male genitalia of Callipia did not advance the research much further. They mirrored the obvious differences between distantly related species (such as C. balteata and C. fulvida), but they were of little value in the discrimination of closely related taxa. DNA barcoding then boosted the process again. The new data provided many clear clusters, and this in turn allowed re-sorting of the material, and then patterns became visible that were much more convincing than the lumping before. One might argue that certain species splits are not sufficiently justified and, in some cases, only a single specimen was available for description. However, more data and new material can always shed more light into these matters in the future. If one, two or three of the new taxa will eventually turn out to be synonyms, then they will be - but in the meantime, there is now a framework available to build upon, and hypotheses that can be tested. It was important to me that as many specimens as possible (and all relevant types) are well illustrated in this paper, and that all molecular information and sampling data are well accessible and presented in the most transparent way, e.g., by providing a Google Earth kml file that allows to explore the distribution data in detail. Doubtlessly more species of Callipia will be discovered in the Andes in the future and, hopefully, much more biological knowledge will be gathered about these beautiful moths and their habitats will be valued and conserved.

\section{Acknowledgements}

I thank Pasi Sihvonen for proof-reading the manuscript and Gerardo Lamas and Sebastian Herzog for locality information in Peru and Bolivia, respectively. Marcel Urban (Jena) kindly provided the background maps for Fig. 2. Axel Hausmann and Bolling Sullivan kindly shared their barcoding data of specimens of Callipia. Curators in various museums provided material for this study and were patient with me in the last years: John W. Brown (USNM), John Chainey and Geoff Martin (NHM), Antoine Lévêque and Rodolphe Rougerie (MNHN), Wolfram Mey (MfN), Eric Quinter and James S. Miller (AMNH), John Rawlins (CMNH), Wolfgang Nässig (SMF), Ole Karsholt (ZMUC), and Axel Hausmann (ZSM). Patricia Gentili-Poole (USNM) kindly allowed access to photographs of type specimens deposited at the USNM. Rodolphe Rougerie successfully sequenced eight old type specimens. Maia Vaswani did some of the genitalia dissection work. DNA-barcoding was supported by the Basler Stiftung für biologische 
Forschung and by funding in support of the International Barcode of Life Project from Genome Canada through the Ontario Genomics Institute. Data analysis was aided by the Barcode of Life Data System, which is supported by the Ontario Ministry of Research and Innovation. Visits to the NHM in 2011 and 2017 were founded by grants from the SYNTHESYS programme (GB TAF1048 and 6817). Support from DFG grants is acknowledged (Fi 547/10-1 and 10-2, FOR 816, FOR 402, Br 2280/6-1).

\section{References}

Brehm G. 2005. A revision of the Acrotomodes clota Druce, 1900 species-group (Lepidoptera: Geometridae, Ennominae). Entomologische Zeitschrift 115: 75-80.

Brehm G. 2015. Three new species of Hagnagora Druce, 1885 (Lepidoptera, Geometridae, Larentiinae) from Ecuador and Costa Rica and a concise revision of the genus. ZooKeys 537: 131-156. https://doi.org/10.3897/zookeys.537.6090

Brehm G. 2017. A new LED lamp for the collection of nocturnal Lepidoptera and a spectral comparison of light-trapping lamps. Nota lepidopterologica 40: 87-108. https://doi.org/10.3897/nl.40.11887

Brehm G. \& Axmacher J.C. 2005. A comparison of manual and automatic moth sampling methods (Lepidoptera: Arctiidae, Geometridae) in a rain forest in Costa Rica. Environmental Entomology 35: 754-764. https://doi.org/10.1603/0046-225X-35.3.757

Brehm G. \& Sullivan B. 2005. Unusual flight activity of a new species of Hagnagora Druce, 1885 (Lepidoptera, Geometridae) from Costa Rica. Entomologische Zeitschrift 115: 256-260.

Brehm G., Bodner F., Strutzenberger P., Hünefeld F. \& Fiedler K. 2011. Neotropical Eois (Lepidoptera: Geometridae): checklist, biogeography, diversity, and description patterns. Annals of the Entomological Society of America 104: 1091-1107. https://doi.org/10.1603/AN10050

Brehm G., Hebert P.D.N., Colwell R.K., Adams M.O., Bodner F., Friedemann K., Möckel L. \& Fiedler K. 2016. Turning up the heat at a hotspot: DNA barcodes reveal $80 \%$ more species of geometrid moths along an Andean elevational gradient. PLOS ONE 11: e0150327.

https://doi.org/10.1371/journal.pone.0150327

Dognin P. 1913. Héterocères nouveaux de l'Amérique du Sud. Mémoires de la Société entomologique de Belgique 22:1-54.

Dognin P. 1914. Héterocères nouveaux de l'Amérique du Sud. Annales de la Société entomologique de Belgique 58:380-417.

Forum Herbulot (2014) Statement on accelerated biodiversity assessment (community consensus position). Spixiana 37: 241-242.

Gaston K.J., Scoble M.J. \& Crook A. 1995. Patterns in species description: a case study using the Geometridae (Lepidoptera). Biological Journal of the Linnean Society 55: 225-237.

https://doi.org/10.1111/j.1095-8312.1995.tb01061.x

GuenéeA. 1858. Callipia parrhasiata.In: Boisduval J.A. \& Guenée A. (eds) Histoirenaturelle des Insectes (Species général des Lépidoptères) 10: 515. Available from https://biodiversitylibrary.org/page/9808283 [accessed 11 Jan. 2018].

Hünefeld F., Brehm G. \& Pohl H. 2013. A simple „hands-off“" apparatus to inflate eversible soft parts of the genitalia of small insect specimens. Microscope Research and Technique 76: 258-263.

https://doi.org/10.1002/jemt.22161

Lamas G. 1976. A gazetteer of Peruvian entomological stations (based on Lepidoptera). Revista Peruana de Entomología 19: 17-25. 
Lafontaine J.D. 2004. Noctuoidea, Noctuidae (part), Noctuinae (part-Agrotini). In: Hodges R.W. (ed.) The Moths of America North of Mexico. Volume 27.1. The Wedge Entomological Research Foundation, Washington.

Lees D.C., Lack H.W., Rougerie R., Hernandez-Lopez A., Raus T., Avtzis N.D., Augustin S. \& Lopez-Vaamonde C. 2011. Tracking origins of invasive herbivores through herbaria and archival DNA: the case of the horse-chestnut leaf miner. Frontiers in Ecology and the Environment 9: 322-328. https://doi.org/10.1890/100098

Oberthür C 1881. Lépidoptères d'Amerique. Études d'entomologie 6: 27-38.

Õunap E., Viidalepp J. \& Truuverk A. 2016. Phylogeny of the subfamily Larentiinae (Lepidoptera: Geometridae): integrating molecular data and traditional classifications. Systematic Entomology 41: 824-843. https://doi.org/10.1111/syen.12195

Parsons M.S., Scoble M.J., Honey M.R., Pitkin L.M. \& Pitkin B.R. 1999. The Catalogue. In: Scoble M.J. (ed.) Geometrid Moths of the World: a Catalogue (Lepidoptera: Geometridae) 2 volumes. CSIRO Publishing, Collingwood.

Ratnasingham S. \& Herbert P.D. 2007. Bold: the barcode of life data system. Molecular Ecology Notes 7: 355-364. https://doi.org/10.1111/j.1471-8286.2007.01678.x

Ratnasingham S. \& Herbert P.D. 2013. A DNA-based registry for all animal species: the Barcode Index Number (BIN) system. PLoS ONE 8: e66213. https://doi.org/10.1371/journal.pone.0066213

Rougerie R., Naumann S. \& Nässig W.A. 2012. Morphology and molecules reveal unexpected cryptic diversity in the enigmatic genus Sinobirma Bryk, 1944 (Lepidoptera: Saturniidae). PLoS ONE 7: e43920. https://doi.org/10.1371/journal.pone.0043920

Scoble M.J. 1992. The Lepidoptera: Form, Function and Diversity. Oxford University Press, Oxford.

Sihvonen P., Mutanen M., Kaila L., Brehm G., Hausmann A. \& Staude H.S. 2011. Comprehensive molecular sampling yields a robust phylogeny for geometrid moths (Lepidoptera: Geometridae). PLoS ONE 6: e20356. https://doi.org/10.1371/journal.pone.0020356

Sperry J.L. 1951. Four South American geometrid moths apparently undescribed. Bulletin of the Southern California Academy of Sciences 50:159-163.

Strutzenberger P., Brehm G. \& Fiedler K. 2012. DNA barcode sequencing from old type specimens as a tool in taxonomy: a case study in the diverse genus Eois (Lepidoptera: Geometridae). PLoS ONE 7: e49710. https://doi.org/10.1371/journal.pone.0049710

Thierry-Mieg P. 1904. Descripcions de Lépidoptères nouveaux. Le Naturaliste 26: 140.

Viidalepp J. 2011. A morphological review of tribes in Larentiinae (Lepidoptera: Geometridae). Zootaxa 3136: 1-44. https://doi.org/10.5281/zenodo.279481

Warren W. 1904. New American Thyrididae, Uraniidae and Geometridae. Novitates Zoologicae 11:1$173,493-582$.

Warren W. 1905. New American Thyrididae, Uraniidae, and Geometridae from South and Central America. Novitates Zoologicae 12: 41-72.

Warren W. 1907. American Thyrididae, Uraniidae, and Geometridae in the Tring Museum. Novitates Zoologicae 14: 187-323. 
Manuscript received: 28 April 2017

Manuscript accepted: 1 August 2017

Published on: 15 February 2018

Topic editor: Gavin Broad

Desk editor: Kristiaan Hoedemakers

Printed versions of all papers are also deposited in the libraries of the institutes that are members of the EJT consortium: Muséum national d'Histoire naturelle, Paris, France; Botanic Garden Meise, Belgium; Royal Museum for Central Africa, Tervuren, Belgium; Natural History Museum, London, United Kingdom; Royal Belgian Institute of Natural Sciences, Brussels, Belgium; Natural History Museum of Denmark, Copenhagen, Denmark; Naturalis Biodiversity Center, Leiden, the Netherlands; Museo Nacional de Ciencias Naturales-CSIC, Madrid, Spain; Real Jardín Botánico de Madrid CSIC, Spain. 


\section{Electronic supplementary material}

\section{Supplementary File 1}

Neighbour joining tree of all DNA barcoded Callipia specimens, generated in Boldsystems (pairwise distance, Bold aligner, Kimura 2 parameter)

\section{Supplementary File 2}

List of all examined Callipia specimens, including label data, and molecular information (BIN number, GenBank accession).

\section{Supplementary File 3}

Google Earth kml file with distribution data. 